Prepared in cooperation with the Alaska Department of Transportation and Public Facilities under Project COPPER RIVER HWY MP 27-49 HYDROLOGY STUDY_AKSAS 61959

\title{
Geomorphology and River Dynamics of the Lower Copper River, Alaska
}

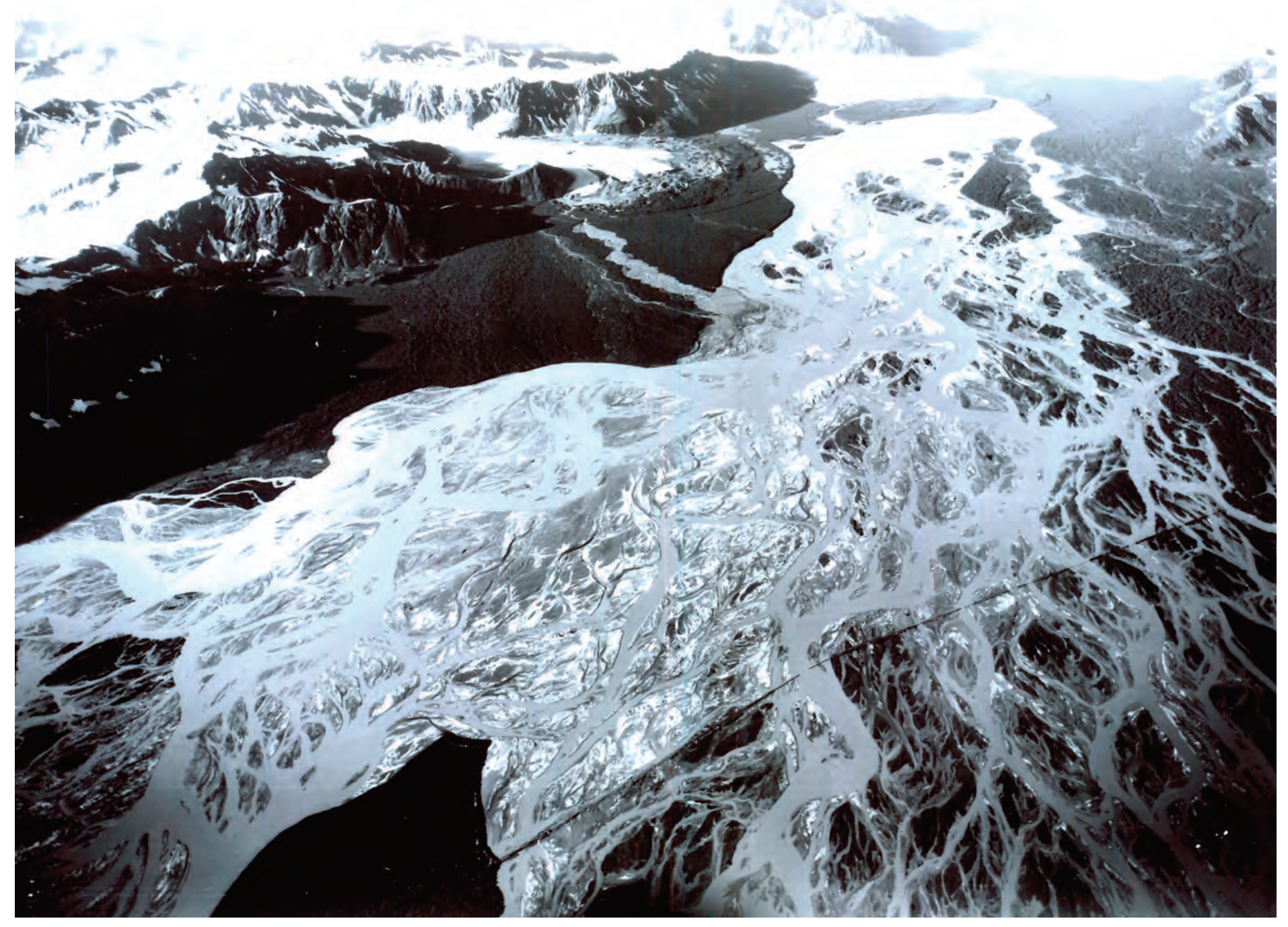

Scientific Investigations Report 2009-5257 
Cover: Lower Copper River in 1944. View is looking north from Mile 35 of the Copper River and Northwestern Railway. (Photograph courtesy of National Archives.) 


\section{Geomorphology and River Dynamics of the Lower Copper River, Alaska}

By Timothy P. Brabets and Jeffrey S. Conaway

Prepared in cooperation with the Alaska Department of Transportation and Public Facilities under Project: COPPER RIVER HWY MP 27-49 HYDROLOGY STUDYAKSAS 61959

Scientific Investigations Report 2009-5257 


\title{
U.S. Department of the Interior \\ KEN SALAZAR, Secretary \\ U.S. Geological Survey \\ Marcia K. McNutt, Director
}

\section{U.S. Geological Survey, Reston, Virginia: 2009}

\author{
For more information on the USGS - the Federal source for science about the Earth, its natural and living resources, \\ natural hazards, and the environment, visit http://www.usgs.gov or call 1-888-ASK-USGS \\ For an overview of USGS information products, including maps, imagery, and publications, \\ visit http://www.usgs.gov/pubprod \\ To order this and other USGS information products, visit http://store.usgs.gov
}

\begin{abstract}
Any use of trade, product, or firm names is for descriptive purposes only and does not imply endorsement by the U.S. Government.

Although this report is in the public domain, permission must be secured from the individual copyright owners to reproduce any copyrighted materials contained within this report.
\end{abstract}

Suggested citation:

Brabets, T.P., and Conaway, J.S., 2009, Geomorphology and river dynamics of the lower Copper River, Alaska: U.S. Geological Survey Scientific Investigations Report 2009-5257, 42 p. 


\section{Contents}

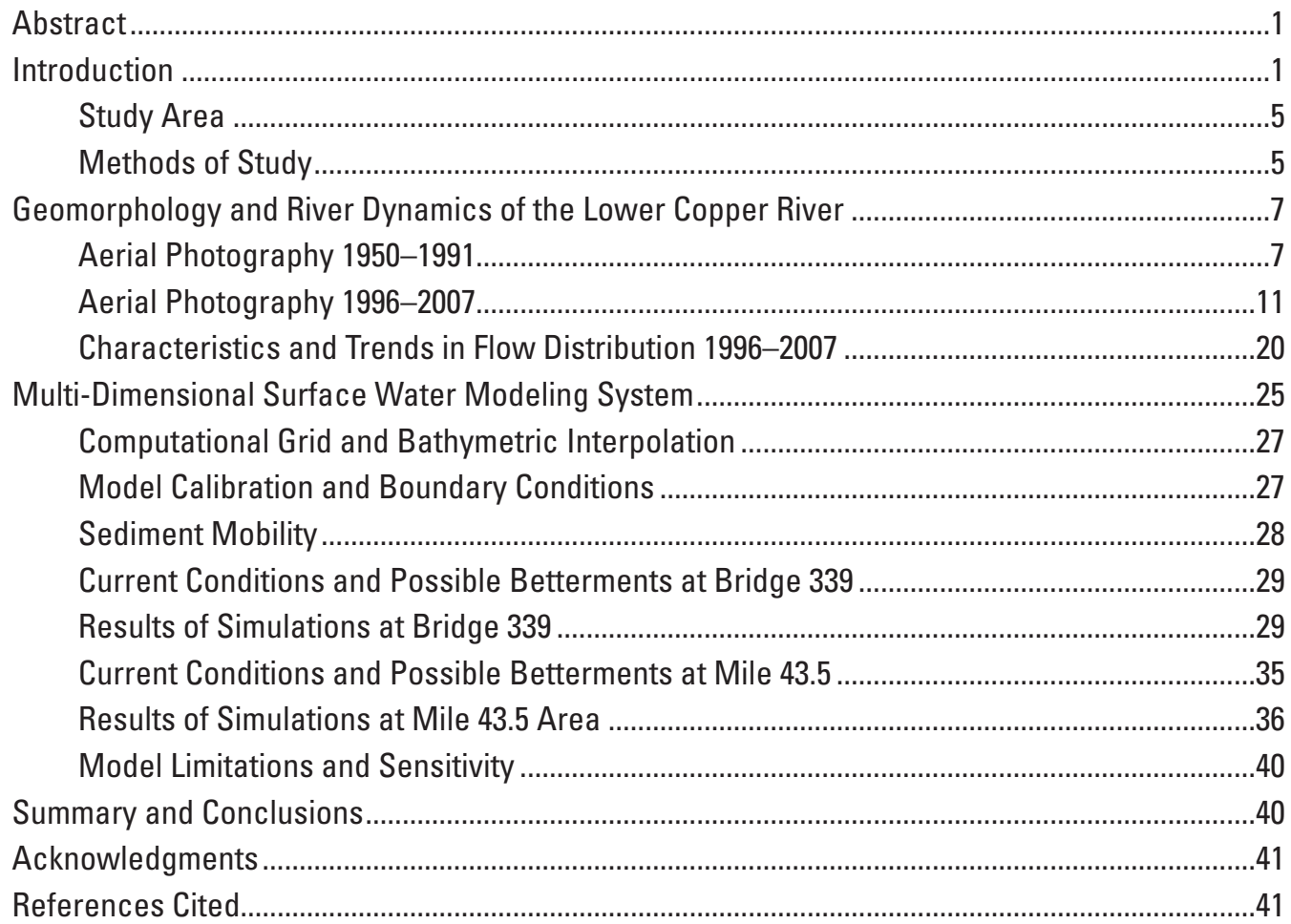

\section{Figures}

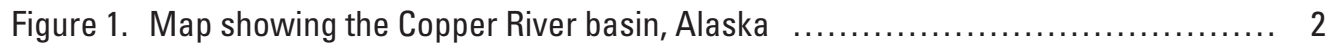

Figure 2. Oblique aerial photograph of the lower Copper River, Alaska $\ldots \ldots \ldots \ldots \ldots \ldots \ldots . . \ldots \ldots$

Figure 3. Map showing locations of bridges along the Copper River Highway, Alaska $\ldots \ldots \quad 4$

Figure 4. Map showing lower Copper River, Alaska ................................. 6

Figure 5. Map showing lower Copper River, Alaska, based on aerial photographs

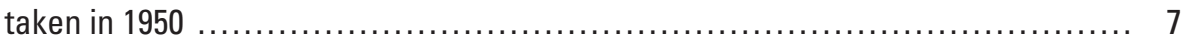

Figure 6. Map showing lower Copper River, Alaska, based on aerial photographs

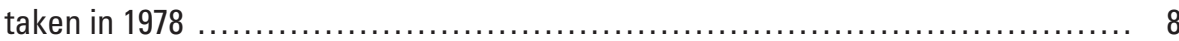

Figure 7. Map showing lower Copper River, Alaska, based on aerial photographs

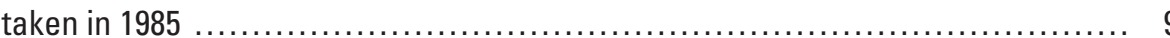

Figure 8. Map showing lower Copper River, Alaska, based on aerial photographs taken in 1991

Figure 9. Map showing lower Copper River, Alaska, based on aerial photographs

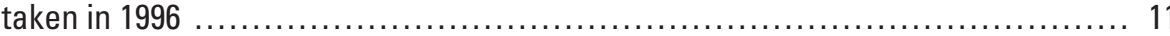

Figure 10. Aerial photographs showing lower Copper River, 1991 and 1996 near Mile 43.5 Copper River Highway, Alaska 


\section{Figures-Continued}

Figure 11. Map showing lower Copper River, Alaska, based on aerial photographs taken in 2002

Figure 12. Aerial photograph of area near Mile 43.5 along the lower Copper River, Alaska, 2002

Figure 13. Aerial photographs of channel change near Bridge 339 in 1996 and 2002, lower Copper River, Alaska

Figure 14. Aerial photographs of area near Mile 43.5 in 2006 and 2007, lower Copper River, Alaska

Figure 15. Photograph showing Copper River Highway looking downstream near Mile 45, lower Copper River, Alaska, August 30, 2007

Figure 16. Photograph showing Copper River Highway from Mile 41 to Mile 44, lower Copper River, Alaska ....

Figure 17. Aerial photographs of area near Bridge 339 in 2006 and 2007, lower Copper River, Alaska

Figure 18. Photograph showing Copper River Highway at Bridge 339, lower Copper River, Alaska

Figure 19. Graph showing discharge of the lower Copper River at the Million Dollar Bridge, lower Copper River, Alaska, 2005-08

Figure 20. Graph showing percentage of total discharge at the Million Dollar Bridge that flows under Bridge 342, lower Copper River, Alaska, 1991-93 and 2005-07

Figure 21. Map and photographs showing areas of the lower Copper River, Alaska, where Multi-Dimensional Surface Water Modeling System was used

Figure 22. Photographs of Copper River Highway road bank material near Bridge 339 looking east and looking west, lower Copper River, Alaska 30

Figure 23. Photograph of Copper River Highway river channels near Bridge 339, lower Copper River, Alaska .... 31

Figure 24. Photograph of Copper River Highway at Bridge 339 showing possible betterments lower Copper River, Alaska

Figure 25. Aerial photographs showing results from MD_SWMS simulation of the main channel near Bridge 339 at a discharge of 32,500 ft3/s

Figure 26. Photograph of area near Mile 45 looking downstream showing location of possible dike to change direction of flow toward the west, lower Copper River, Alaska

Figure 27. Graphs showing measured compared with computed water-surface elevations for various discharges, computed by Multi-Dimensional Surface Water Modeling System, lower Copper River, Alaska

Figure 28. Maps showing water surface-elevations computed by Multi-Dimensional Surface Water Modeling System for a flow of 177,000 ft3/s without dike and with dike, near Mile 43.5, lower Copper River, Alaska 


\section{Tables}

Table 1. Summary of flow conditions at the Million Dollar Bridge, lower Copper River,

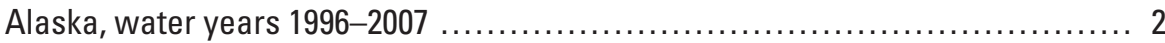

Table 2. Discharge at bridges along the Copper River Highway, lower Copper River, Alaska, 2005-07

Table 3. Percentage of discharge at selected bridges along the Copper River Highway, lower Copper River, Alaska, 2005-07.

Table 4. Sediment grade scale and critical shear stress for determining approximate condition for sediment mobility at 20 degrees Celsius

Table 5. Discharges and boundary conditions used by Multi-Dimensional Surface Water Modeling System for Mile 43.5 area of the lower Copper River, Alaska ...

Table 6. Results of sensitivity analysis of Muti-Dimensional Surface Water Modeling System when drag coefficient is adjusted plus and minus 25 percent for Bridge 339 area, lower Copper River, Alaska....

\section{Conversion Factors and Datums}

Conversion Factors

\begin{tabular}{lcl}
\hline \multicolumn{1}{c}{ Multiply } & By & \multicolumn{1}{c}{ To obtain } \\
\hline inch (in.) & Length & \\
inch (in.) & 2.54 & centimeter $(\mathrm{cm})$ \\
foot (ft) & 25.4 & millimeter $(\mathrm{mm})$ \\
mile (mi) & 0.3048 & meter $(\mathrm{m})$ \\
\hline & 1.609 & kilometer $(\mathrm{km})$ \\
\hline square foot $\left(\mathrm{ft}^{2}\right)$ & Area & square meter $\left(\mathrm{m}^{2}\right)$ \\
square mile $\left(\mathrm{mi}^{2}\right)$ & 0.09290 & square kilometer $\left(\mathrm{km}^{2}\right)$ \\
\hline & 2.590 & meter per second $(\mathrm{m} / \mathrm{s})$ \\
\hline foot per second $(\mathrm{ft} / \mathrm{s})$ & Flow rate & cubic meter per second $\left(\mathrm{m}^{3} / \mathrm{s}\right)$ \\
cubic foot per second $\left(\mathrm{ft}^{3} / \mathrm{s}\right)$ & 0.3048 & cubic meter per second per square \\
cubic foot per second per square & 0.02832 & kilometer $\left[\left(\mathrm{m}^{3} / \mathrm{s}\right) / \mathrm{km}^{2}\right]$ \\
mile $\left[\left(\mathrm{ft}^{3} / \mathrm{s}\right) / \mathrm{mi}^{2}\right]$ & 0.01093 & \\
\hline & & Newtons per square meter $\left(\mathrm{N} / \mathrm{m}^{2}\right)$ \\
\hline pound per square $\mathrm{ft}\left(\mathrm{lb} / \mathrm{ft}^{2}\right)$ & Shear stress & meter squared per second $\left(\mathrm{m}^{2} / \mathrm{s}\right)$ \\
\hline
\end{tabular}

\section{Datums}

Vertical coordinate information is referenced to the North American Vertical Datum of 1988 (NAVD 88).

Horizontal coordinate information is referenced to the North American Datum of 1983 (NAD 83). Altitude, as used in this report, refers to distance above the vertical datum. 
This page intentionally left blank. 


\title{
Geomorphology and River Dynamics of the Lower Copper River, Alaska
}

\author{
By Timothy P. Brabets and Jeffrey S. Conaway
}

\section{Abstract}

Located in south-central Alaska, the Copper River drains an area of more than 24,000 square miles. The average annual flow of the river near its mouth is 63,600 cubic feet per second, but is highly variable between winter and summer. In the winter, flow averages approximately 11,700 cubic feet per second, and in the summer, due to snowmelt, rainfall, and glacial melt, flow averages approximately 113,000 cubic feet per second, an order of magnitude higher. About 15 miles upstream of its mouth, the Copper River flows past the face of Childs Glacier and enters a large, broad, delta. The Copper River Highway traverses this flood plain, and in 2008, 11 bridges were located along this section of the highway. The bridges cross several parts of the Copper River and in recent years, the changing course of the river has seriously damaged some of the bridges.

Analysis of aerial photography from 1991, 1996, 2002, 2006, and 2007 indicates the eastward migration of a channel of the Copper River that has resulted in damage to the Copper River Highway near Mile 43.5. Migration of another channel in the flood plain has resulted in damage to the approach of Bridge 339. As a verification of channel change, flow measurements were made at bridges along the Copper River Highway in 2005-07. Analysis of the flow measurements indicate that the total flow of the Copper River has shifted from approximately 50 percent passing through the bridges at Mile 27, near the western edge of the flood plain, and 50 percent passing through the bridges at Mile 36-37 to approximately 5 percent passing through the bridges at Mile 27 and 95 percent through the bridges at Mile 36-37 during average flow periods.

The U.S. Geological Survey's Multi-Dimensional Surface-Water Modeling System was used to simulate watersurface elevation and velocity, and to compute bed shear stress at two areas where the Copper River is affecting the Copper River Highway. After calibration, the model was used to examine the effects that betterments, such as guide banks or bridge extensions, would have on flow conditions and to provide sound conceptual information that could help decide if a proposed betterment will work or determine potential problems that need to be addressed for a particular betterment.
The ability of the model to simulate these hydraulic conditions was constrained by the accuracy and level of channel geometry detail, which is constantly changing in the lower Copper River.

\section{Introduction}

The Copper River basin, with a drainage area of $24,200 \mathrm{mi}^{2}$, is the sixth largest basin in Alaska. Its headwaters lie in the Alaska Range to the north, the Wrangell-St. Elias Mountains to the east, and the Talkeetna Mountains to the west (fig. 1). Along its upper course, the Copper River is fed by many glacial streams from high mountains. The river flows southward to the Gulf of Alaska and is the only river that bisects the Chugach Mountains, which effectively divide the climate of the Copper River basin into two distinct types. The larger part of the basin lies north of the Chugach Mountains, within the cold and arid climate of interior Alaska. South of the range, a maritime climate with moderate temperatures and high precipitation prevails. The total length of the Copper River is approximately $290 \mathrm{mi}$ with an average gradient of about $12 \mathrm{ft} / \mathrm{mi}$ (Quinn, 1995). In the lower reach, near the mouth of the river, the average gradient is about $6 \mathrm{ft} / \mathrm{mi}$. Most of the valleys of the Copper River and its tributaries are incised in the Copper River Lowlands, a relatively smooth plain that ranges in altitude from approximately 1,000 to 3,000 ft (Wahrhaftig, 1965). Glaciation has been the major force in creating present-day landforms in the basin. Glaciers and glacial lakes have at one time or another covered most of the area. In 2007, approximately 18 percent of the Copper River basin consisted of glaciers. During the winter months (November through April), the river is ice covered and flow averages $11,700 \mathrm{ft}^{3} / \mathrm{s}$ near the mouth. During the open-water months (May through October), however, glaciers contribute significant flow to the Copper River, and average flow increases by an order of magnitude-to 113,300 $\mathrm{ft}^{3} / \mathrm{s}$ near the mouth. Additionally, the lower Copper River is subject to rapid increases in flow about every 6 years when the glacierdammed Van Cleve Lake breaks out. 


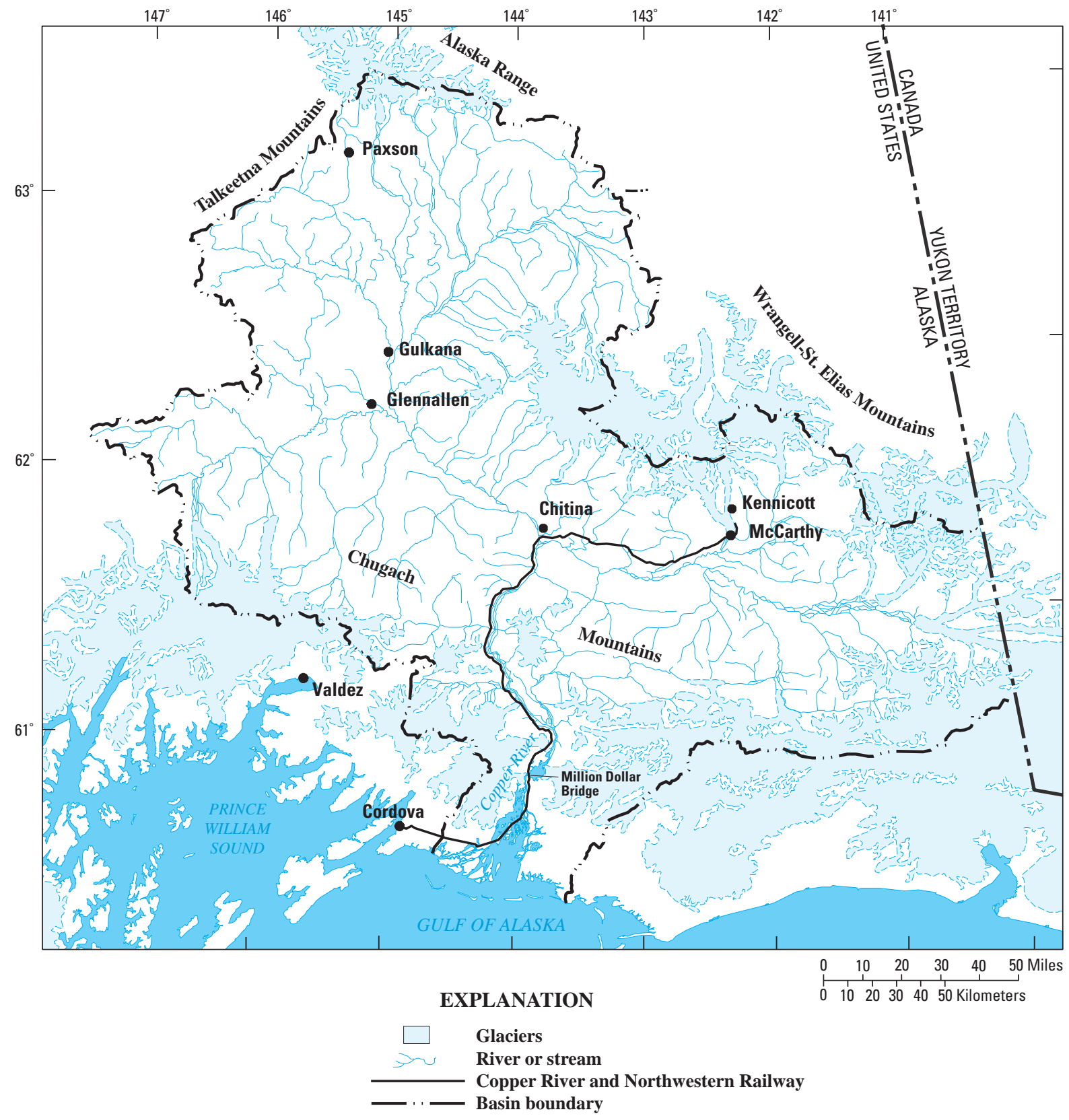

Figure 1. Copper River basin, Alaska.

The lower Copper River flows into a large, relatively flat, alluvial plain near its mouth (figs. 1-2). As with many alluvial systems, the banks and streambeds of the lower Copper River are readily erodible and less permanent than most other aspects of the landscape. Many braided channels are formed, depending on the quantity and type of available sediment and the quantity and variability of discharge. The pattern of flow of water and sediment in these alluvial channels is complex and involves the mutual adjustment of a number of variables such as water discharge, sediment discharge, and slope (Maddock, 1969). However, hydraulics and hydrology are not always the dominant factors (Schumm and Winkley, 1994). Geologic controls such as uplift or subsidence may also influence the alluvial system over long periods of time. 


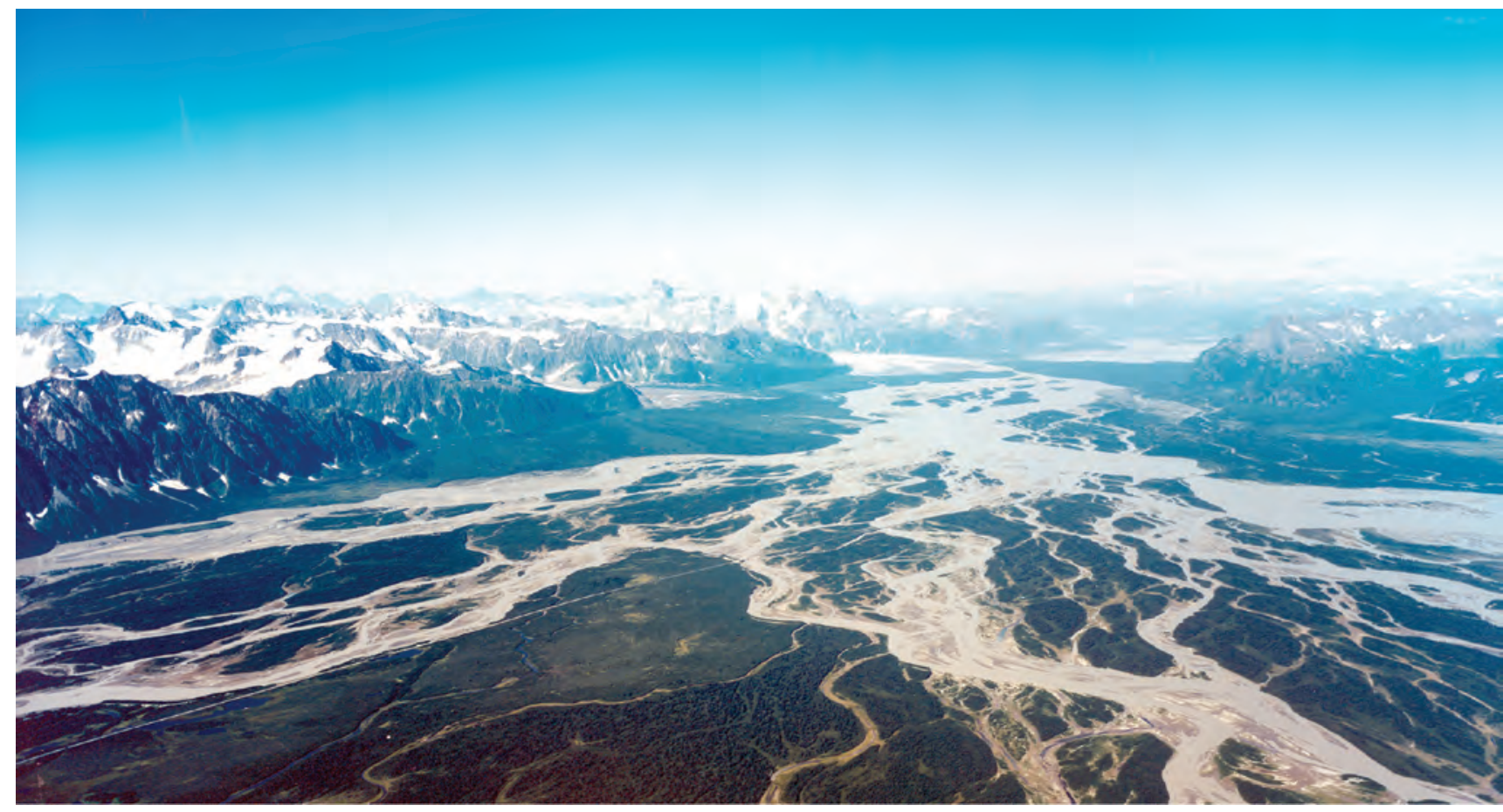

Figure 2. Lower Copper River, Alaska. (Photograph taken by AeroMetric, August 11, 2007.)

The huge potential value of copper ore in interior Alaska created a demand to build a railroad in the early 1900s. A route along the Copper River from Cordova eventually was selected. Construction of the Copper River and Northwestern Railroad was started in 1907 and was completed in 1911. The main line of the railway ran $130.7 \mathrm{mi}$ from Cordova to Chitina (fig. 1) and from Chitina, a 65-mi branch continued to the Kennecott copper mines. The Kennecott mines operated from 1911 until late 1938; closure of the Kennecott mines in 1938 ended the Copper River and Northwestern Railway. From 1945 to 1973, the rail bed was gradually converted to the Copper River Highway, beginning at Cordova and extending about $25 \mathrm{mi}$ past the Million Dollar Bridge.

On March 27, 1964, an earthquake of Richter magnitude 9.2 occurred in south-central Alaska, which raised the Copper River Delta about $6 \mathrm{ft}$ (Plafker, 1969). Seismic shaking caused compaction and subsidence at most of the bridge approaches on the Copper River Highway. During the earthquake, all bridges supported by piles made of old rails were severely damaged or destroyed because the brittle rail piles were unable to withstand the severe shaking generated by the earthquake (Kachadoorian, 1968). The severe seismic shaking caused the $405 \mathrm{ft}$ span on the north side of the Million Dollar Bridge to fall from its pier support to the river bottom. Reconstruction of the bridges between Flag Point and the Million Dollar Bridge began in 1970. At some locations along the highway where the Copper River had shifted away from the road, bridges were not rebuilt, but rather the bridge opening was filled in. When reconstruction along the delta was completed in 1978, 11 bridges (fig. 3) were located between Flag Point and Mile 40 of the highway. Reconstruction and raising of the north span of the Million Dollar Bridge was started in 2004 and was completed in 2005. 


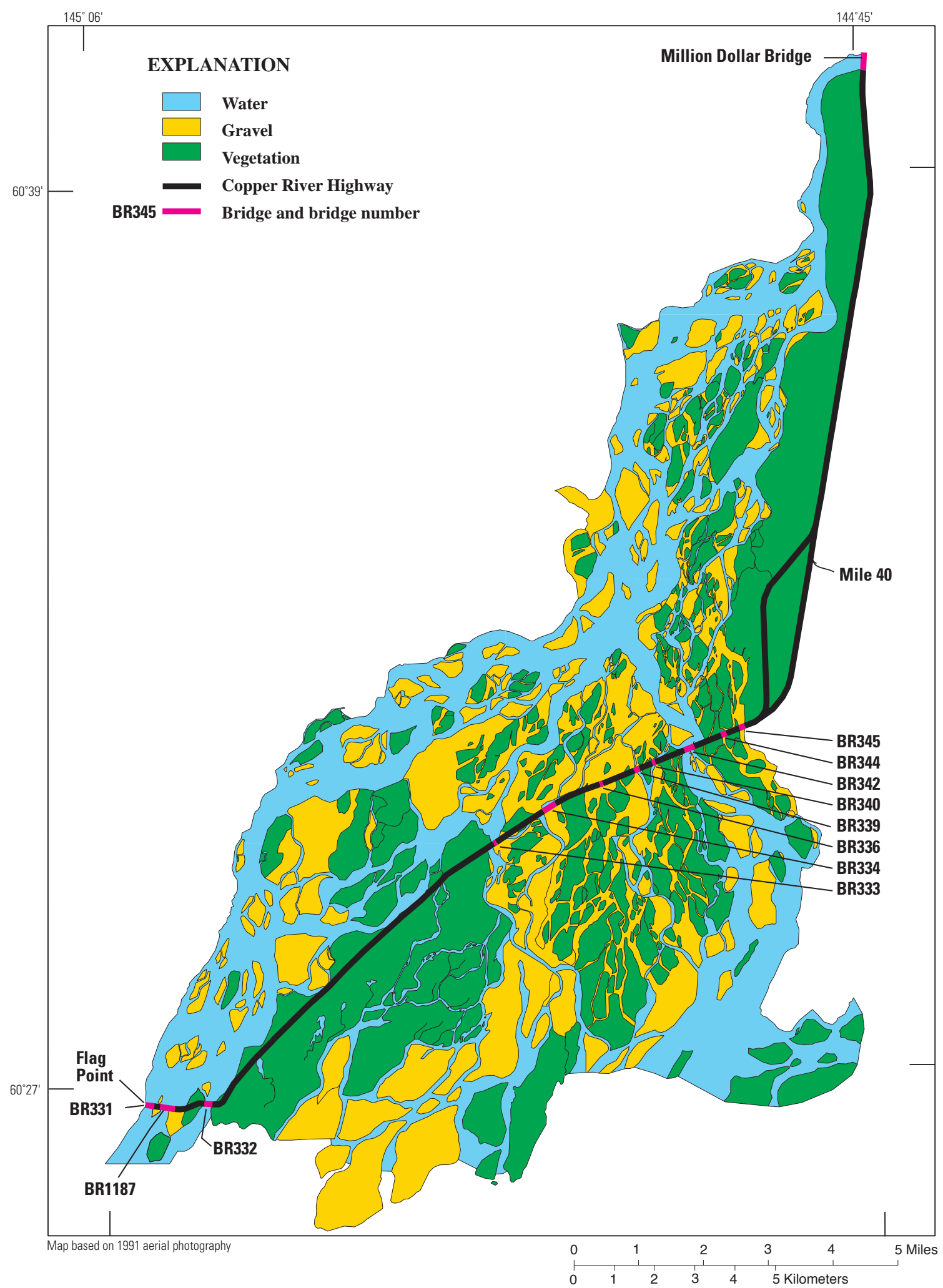

Figure 3. Locations of bridges along the Copper River Highway, Alaska. 
Beginning in Cordova, the Copper River Highway heads east/northeastward for about $48 \mathrm{mi}$. From mile 27, also known as Flag Point, to about mile 38, the highway crosses the alluvial plain of the lower Copper River (fig. 4). Lengths of the 11 bridges (fig. 3) range from 240 to $1,200 \mathrm{ft}$. Three bridges at Flag Point were built on concrete piers and the remaining bridges were built on concrete filled steel pilings. Spur dikes were constructed at some bridges to direct river flow perpendicular to the bridge opening.

Changes in the alluvial system of the lower Copper River have caused significant bridge scour and damage to the Copper River Highway. In the mid-to-late 1980s and early 1990s, a major channel shift of the Copper River resulted in an increase in the proportion of total flow toward and through Bridge 342 (Brabets, 1997). As originally constructed, Bridge 342 was $400 \mathrm{ft}$ long. Due to channel change, the bridge was not able to convey the increased flow. Approximately 10 million dollars were spent on widening the bridge to 880 $\mathrm{ft}$ to convey the increased flow and constructing spur dikes to realign the flow perpendicular to the bridge. In 2001, a channel shift near Mile 44 washed out a 3 to 4 mile stretch of the Copper River Highway. Also in 2001, a channel shift near Mile 36 caused more flow to be directed toward Bridge 339 damaging the road approach to the bridge.

Maintaining existing roads or designing structures such as bridges or spur dikes in alluvial channels is difficult, primarily because streambed patterns in the lower Copper River constantly change. The channels near these structures may scour or fill, or move laterally. Compounding the problem, channel instability is spatially variable, and channel migration may not affect the entire length equally. Thus, in dealing with problems such as bridge scour or flood impacts in an alluvial setting, it is important to view the problem in terms of the larger fluvial system. In this way, it is possible to understand more fully the cause of bridge scour or the effects of large floods, and to predict better the consequences of proposed mitigation measures. If past and present conditions are known and this information is incorporated in the analysis of the fluvial system, the ability to predict future changes likely will be improved.

With the goal of obtaining a better understanding of the geomorphology and river dynamics of the lower Copper River, the Alaska Department of Transportation and Public Facilities (ADOT\&PF) and the U.S. Geological Survey (USGS) entered into a cooperative agreement in 2005. This report describes the geomorphology and river dynamics of the lower Copper River from 1991 to the present. The report includes: (1) a short retrospective of geomorphic changes from 1950 to 1991 based on an earlier report by Brabets (1997); (2) documentation of geomorphic changes from 1991 to 2007; and (3) application of a hydrodynamic model to assess future changes in the lower Copper River and the effects of control structures such as spur dikes or guide banks in safeguarding the Copper River Highway.

\section{Study Area}

The study area for this report consists of the area bounded on the northeast by Van Cleve Lake and on the south by the Copper River alluvial plain (fig. 4), approximately $1 \mathrm{mi}$ south of the Copper River Highway. Three major glaciers lie within the study area: Miles, Childs, and Goodwin Glaciers (fig. 4). As the Copper River flows past Childs Glacier, the flood plain widens considerably. The river valley is less confined and is more than three times wider than it is near the terminus of Childs Glacier. In the upper part of the study area, near the Million Dollar Bridge, the deposits are primarily glacial-gravel and boulders with diameters as much as $3 \mathrm{ft}$. In the lower part of the alluvial plain, downstream of Childs Glacier, the deposits are fine-grained alluvium. Many braided and shifting channels dissect the alluvial plain.

\section{Methods of Study}

Some of the most important variables that influence alluvial systems are changes in water discharge, changes in sediment load, movement of the riverbed, and lateral shifts of the channels. These variables were studied by (1) collecting and analyzing water discharge, (2) compiling and interpreting aerial photographs, (3) collecting topography and bathymetry data, and (4) using a hydraulic model to simulate the alluvial system. The methods used in this study to examine these variables were (1) collection and analysis of discharge data, (2) compilation and interpretation of aerial photographs, (3) collection of topographic and bathymetric data, and (4) use of a hydraulic model to simulate the alluvial system. 


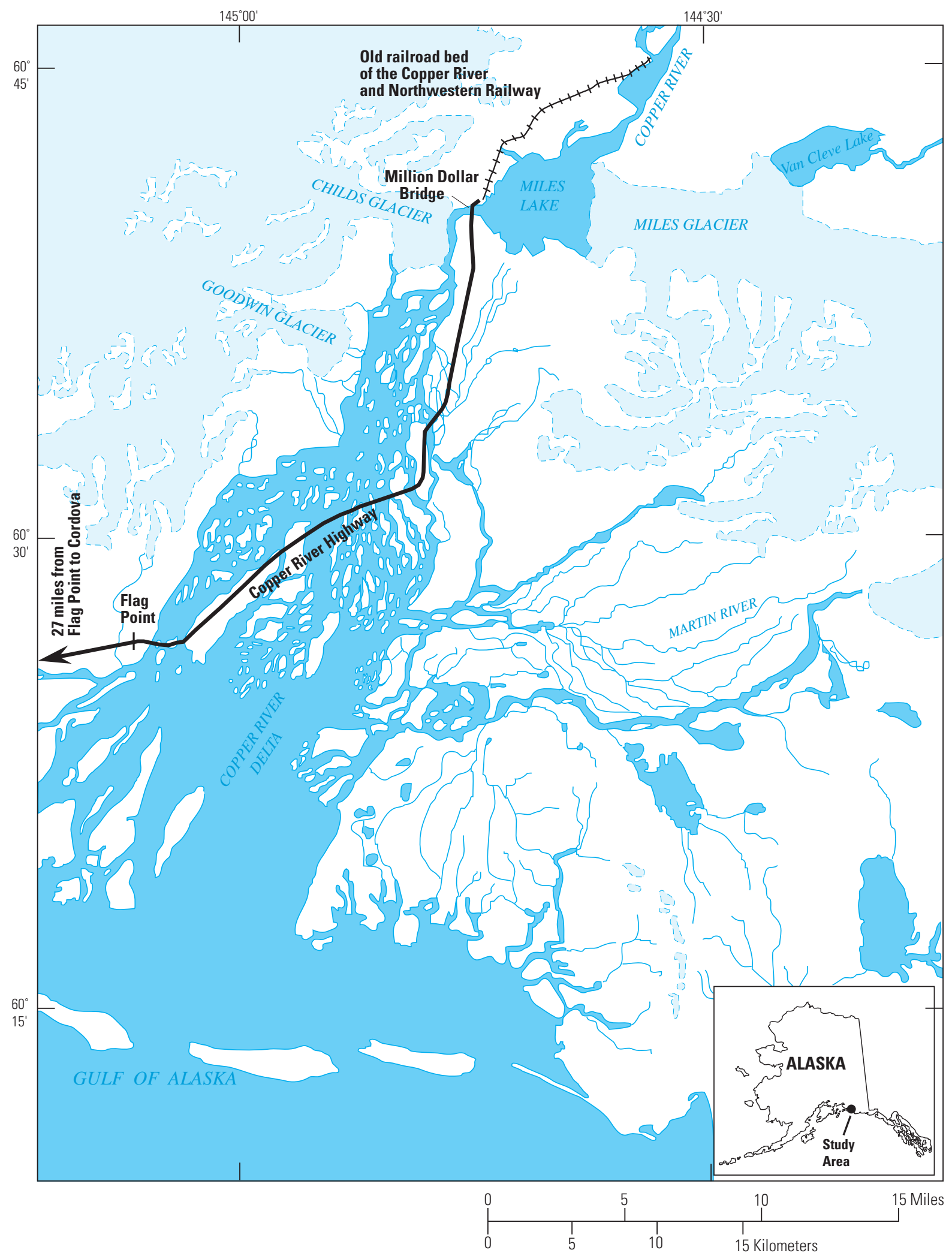

Figure 4. Lower Copper River, Alaska. 


\section{Geomorphology and River Dynamics of the Lower Copper River}

\section{Aerial Photography 1950-1991}

Analysis of aerial photography obtained at different times is one of the best techniques to document channel changes in a large, braided stream such as the Copper River. In a previous study of the lower Copper River, Brabets (1997) analyzed 8 years of photography: 1950, 1965, 1971, 1974, 1978, 1982, 1985, and 1991. A summary of this analysis provides a broad overview of the historical changes in the lower Copper River. The reader is referred to Brabets (1997) for a more detailed discussion.

In 1950, the Copper River flowed south/southwestward toward Flag Point (fig. 5). A secondary channel flowed primarily southward toward Bridge 345 . Most of the flow

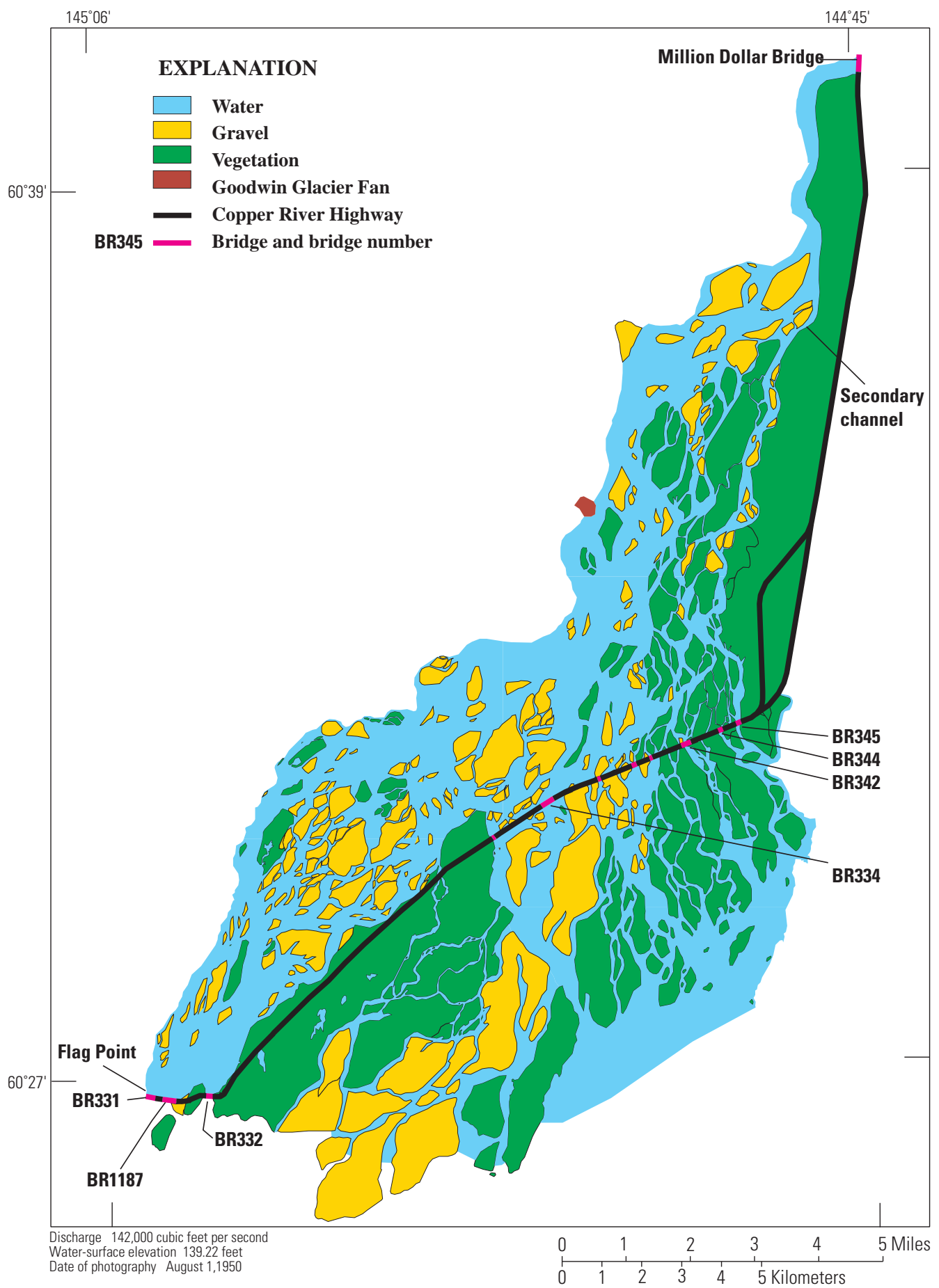

Figure 5. Lower Copper River, Alaska, based on aerial photographs taken in 1950. 
passed through the Flag Point bridges and Bridge 334. Flow patterns in 1965 were similar to those in 1950. Examination of photographs taken in 1971 indicated no major channel changes, and discharge measurements confirmed that most of the flow still passed through the bridges at Flag Point. Some of the vegetated area in the secondary channel near Mile 45 changed to water or gravel, eroded into water or gravel, indicating that more flow was entering this channel. In the area near Bridge 342, previously vegetated areas were now water or gravel, indicating some channel shifting or widening in this area. The 1974 photography showed some changes of vegetated areas near Bridge 342 and Bridge 334 to gravel or water, indicating that the channel was beginning to shift. Flow patterns shown on photographs taken in 1978 were similar to those in 1974 (fig. 6). Downstream of the Copper River Highway, from Bridge 334 to Bridge 342, no major channel changes were noted. A few vegetated areas changed to gravel or water, indicating that more flow was passing through these bridges.

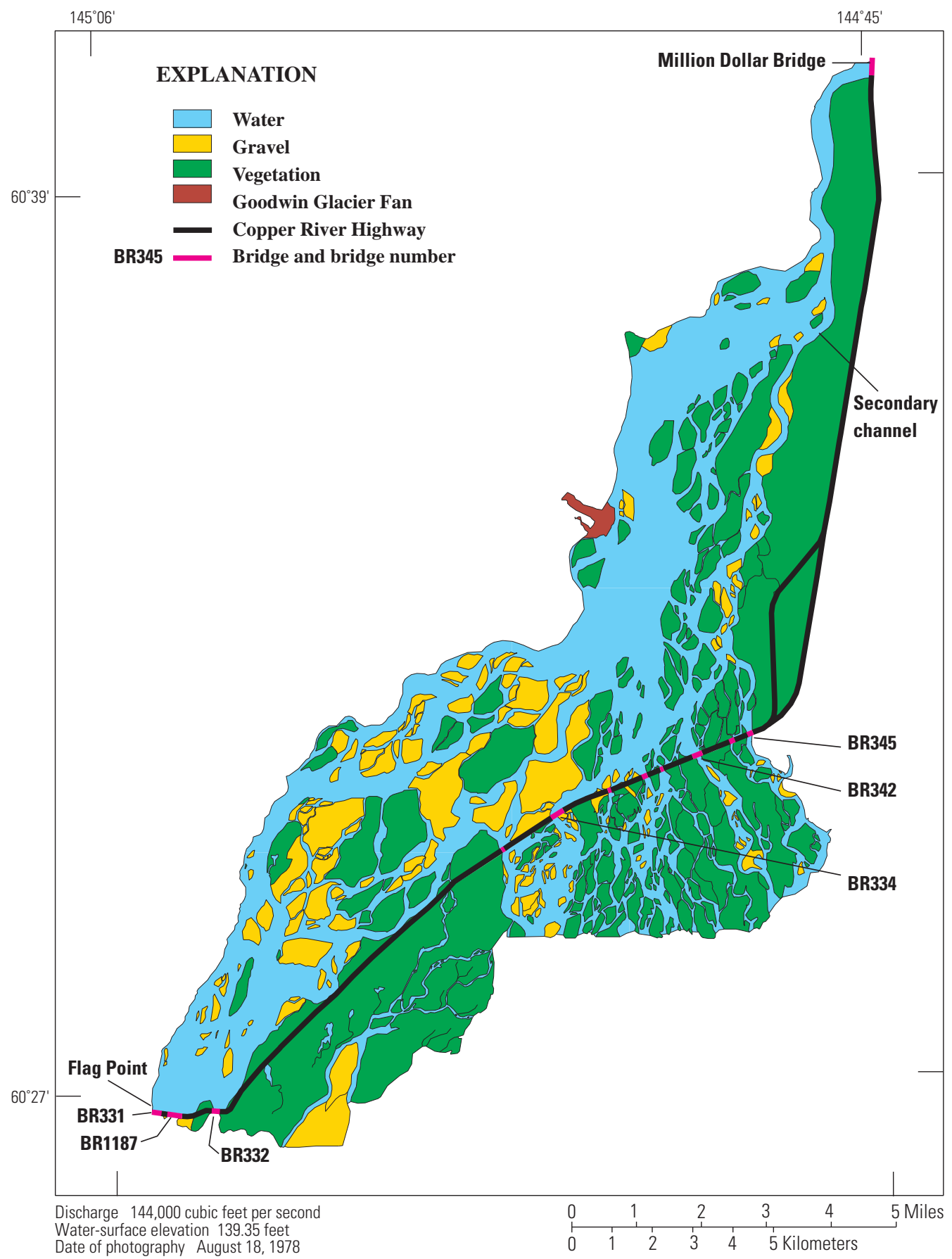

Figure 6. Lower Copper River, Alaska, based on aerial photographs taken in 1978. 
Several significant hydrologic events occurred from 1978 to 1982, including a flood in August 1981 with an estimated peak discharge of $470,000 \mathrm{ft}^{3} / \mathrm{s}$, which has approximately a 1 percent chance of occurrence in any given year. During the flood, the Copper River Highway was breached at the approach to Bridge 342. Notable changes shown in the aerial photographs taken in 1985 included more gravel areas downstream of Bridge 334 (fig. 7), indicating that the 1981 flood deposited a large amount of sediment in the southwest part of the study area. The 1981 flood likely caused a major channel shift away from this part of the lower Copper River toward Bridge 342 (fig. 7). As a further indicator of channel change, the channel was wider downstream of Bridge 342 in 1985 than it was in 1978, indicating that more flow was passing through Bridge 342. Also noted in the 1985 photography is the presence of two distinct channels: one leading to Bridge 342 and the other leading to Flag Point.

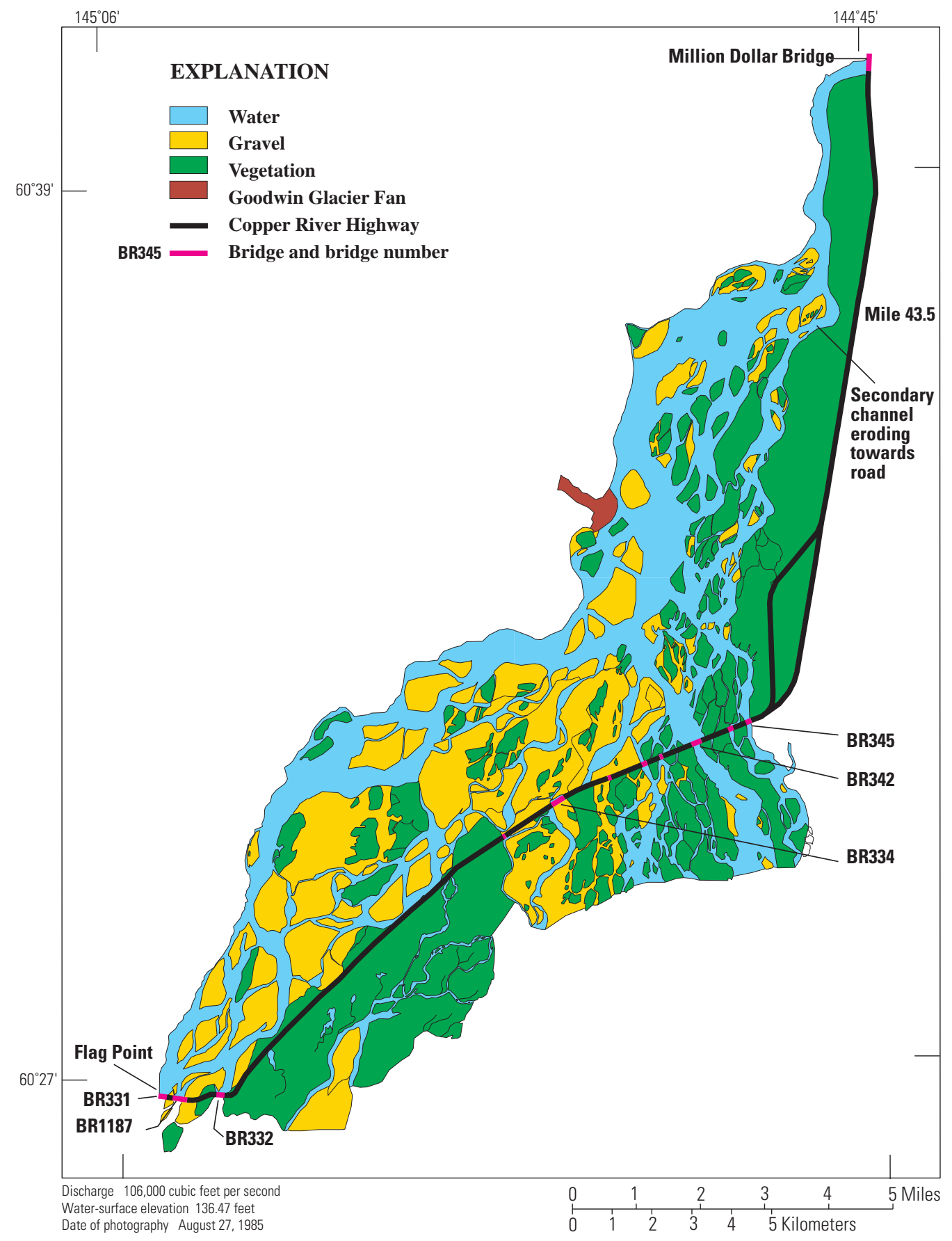

Figure 7. Lower Copper River, Alaska, based on aerial photographs taken in 1985. 
At Mile 43.5 of the Copper River Highway, a considerable quantity of bank material had eroded. This was not present in the 1978 photography and is likely to have occurred during the sustained high flows in 1981.

The 1991 photography, shows a major channel change (from 1985) about $1.5 \mathrm{mi}$ west of mile 41.5 of the Copper River Highway (fig. 8). At this location, a new channel bisected a large vegetated island. The formation of this channel decreased flow in the channels leading to Bridges 344 and 345. During 1991-95, these channels were dry except during high flows (Brabets, 1997). Two distinct channels, one toward Bridge 342 and one toward Flag Point, were still evident in 2009.

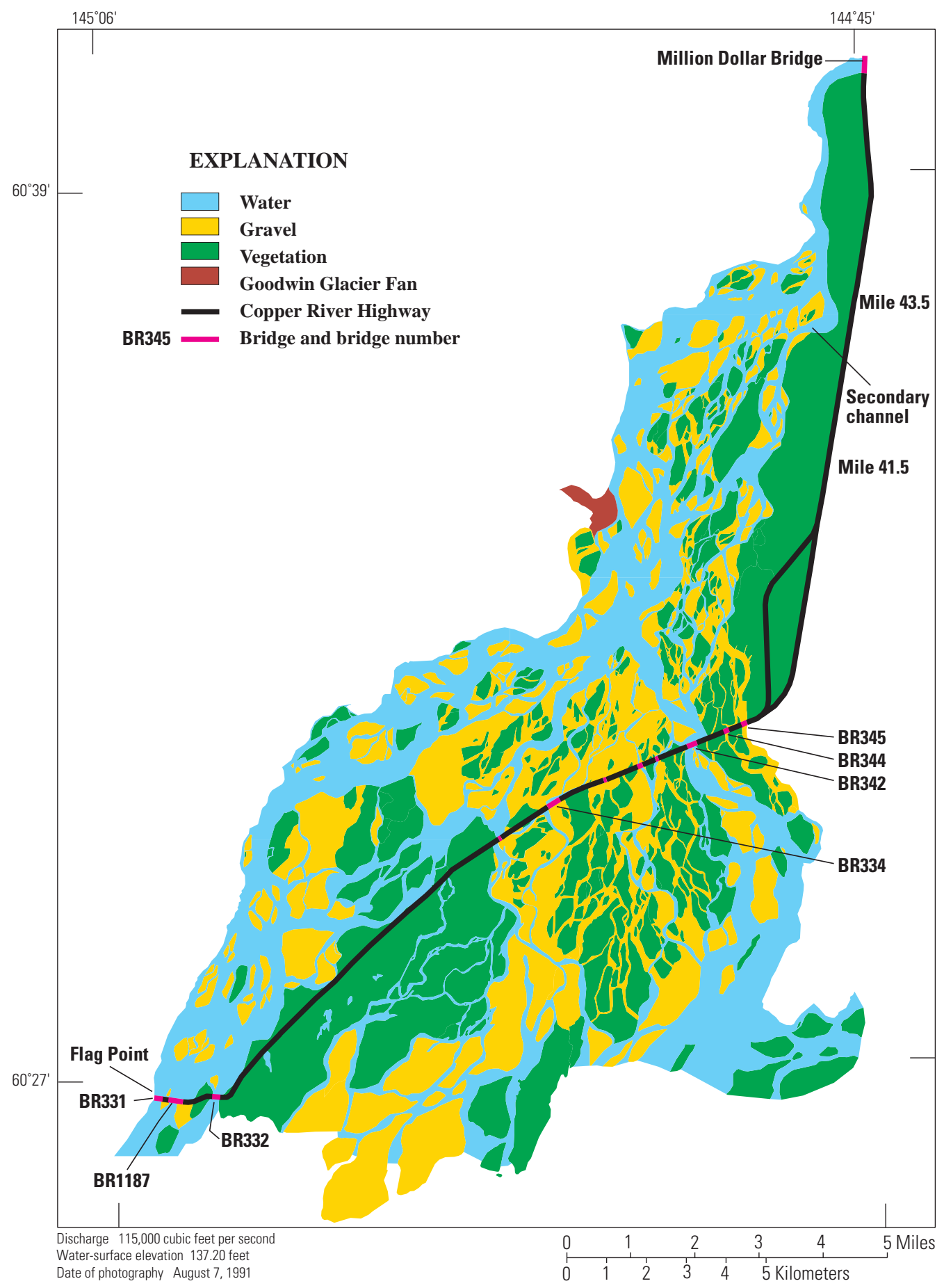

Figure 8. Lower Copper River, Alaska, based on aerial photographs taken in 1991. 


\section{Aerial Photography 1996-2007}

In the present study, an additional 4 years of photography have been analyzed-1996, 2002, 2006, and 2007. The 1996 aerial photographs were taken at a river stage of $138.16 \mathrm{ft}$ at the Million Dollar Bridge (fig. 9), about $1 \mathrm{ft}$ higher than the stage at the time of the 1991 photography. Comparison of the 1991 and 1996 photographs indicate only minor channel changes of the Copper River (figs. 8 and $\underline{9}$ ). Significant flow still was present at Flag Point. Near Mile 43.5, the sharp curvature of the channel near the Copper River Highway had changed to a more gentle one (fig. 10), but there was no significant migration of the channel toward the highway.

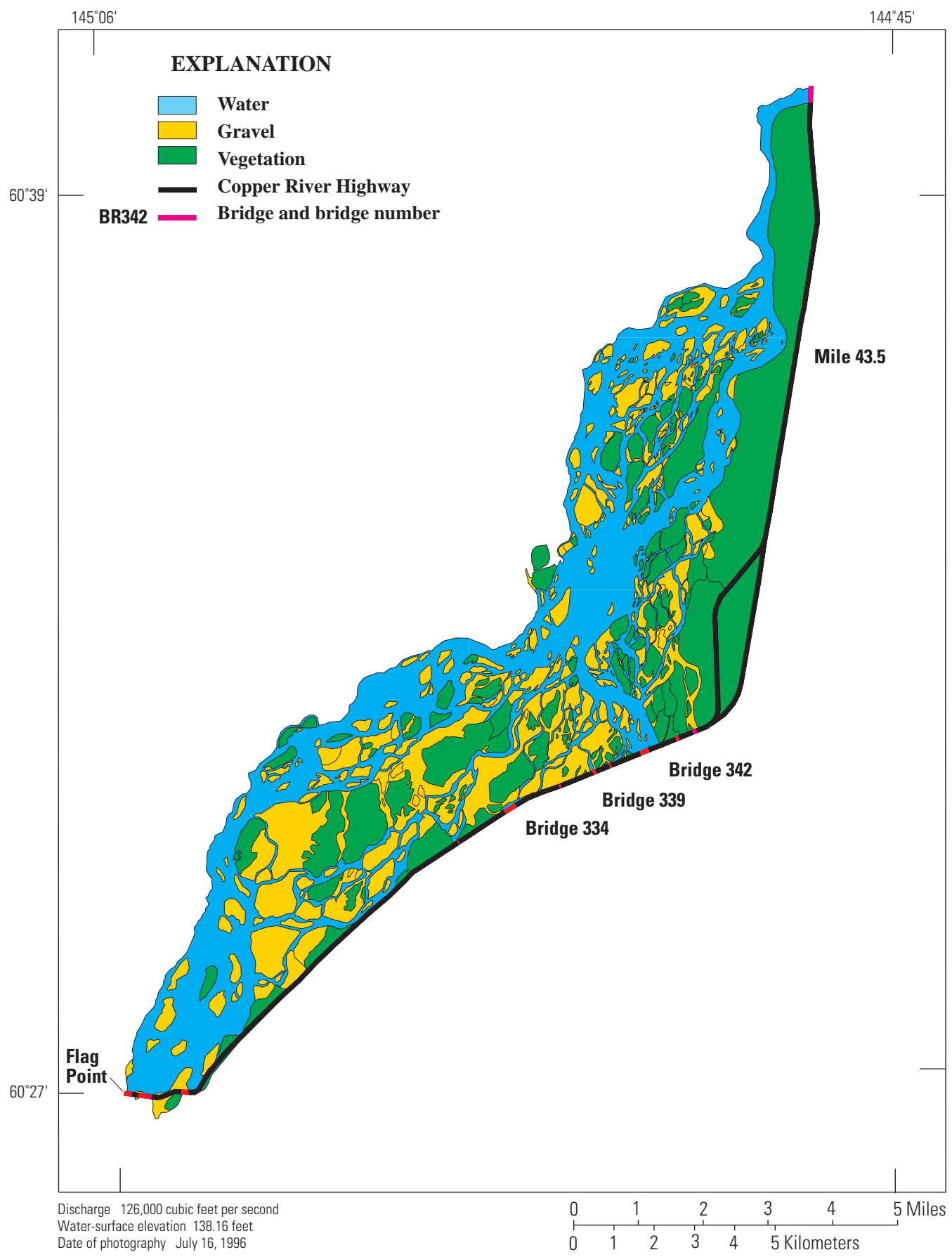

Figure 9. Lower Copper River, Alaska, based on aerial photographs taken in 1996. 


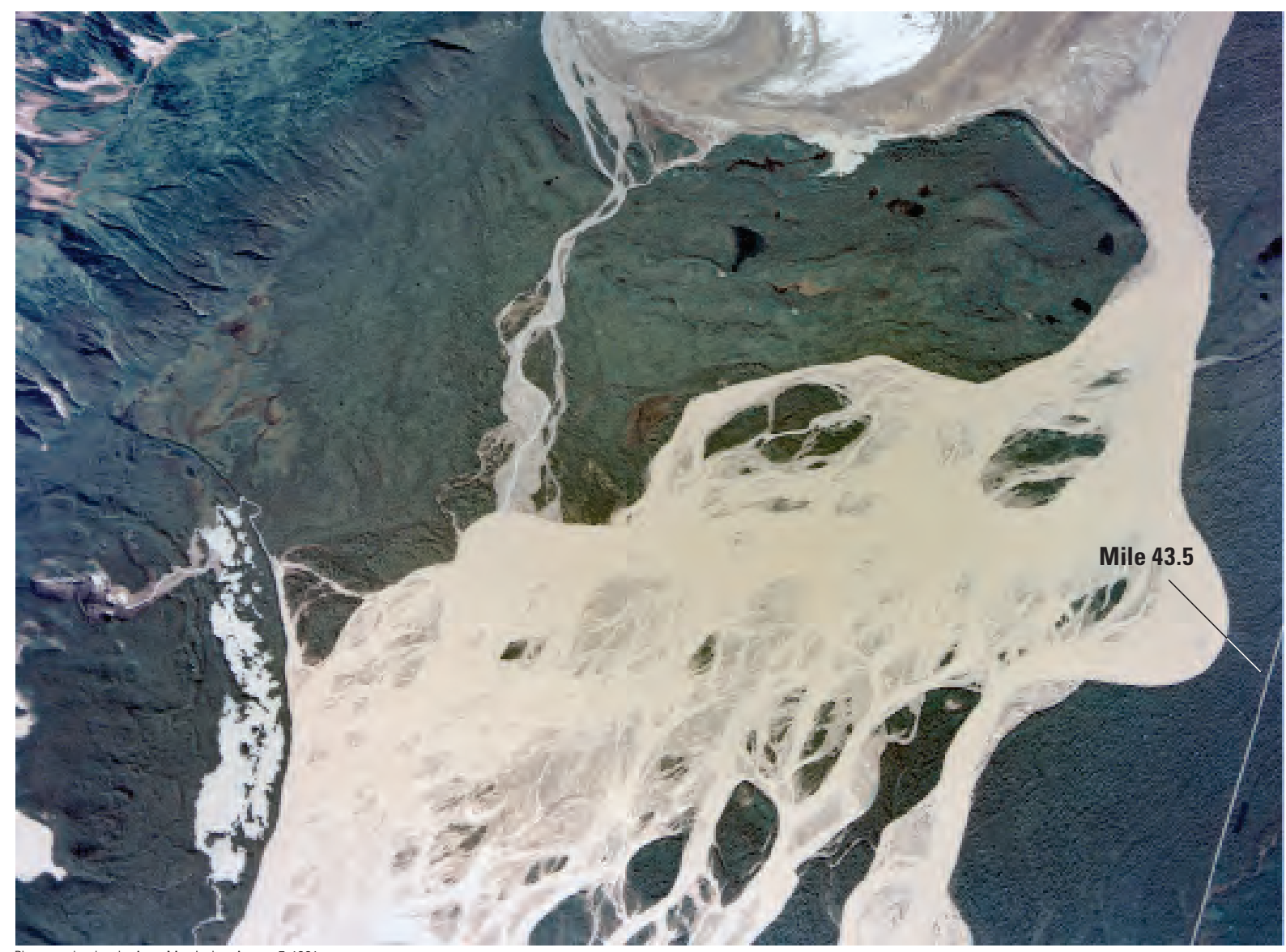

Photograph taken by Aero-Metric, Inc. August 7, 1991

A. 1991

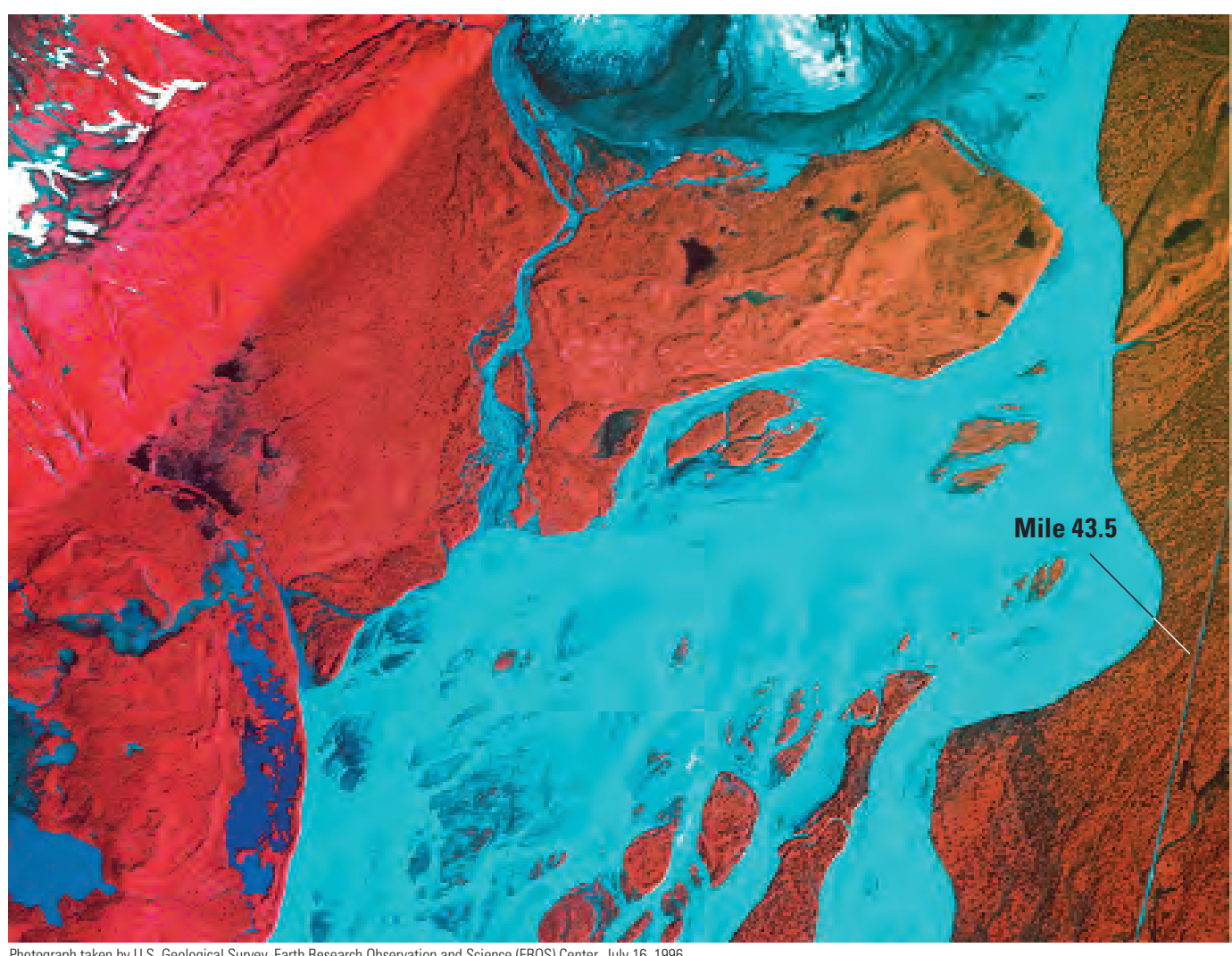

Figure 10. Lower Copper River, $(A) 1991$ and $(B) 1996$ near Mile 43.5 Copper River Highway, Alaska. 
The 2002 aerial photographs (fig. 11) were taken when stage was about $136 \mathrm{ft}$ at the Million Dollar Bridge, which was about $2 \mathrm{ft}$ lower than the stage during the 1996 photography. Between 1996 and 2002, three significant changes occurred. The first change was the creation of a new channel near Mile 43.5 of the Copper River Highway. The Copper River had cut through a low-lying section of land adjacent to the highway (fig. 12) and re-occupied an old channel, inundating an area adjacent to the highway (fig. 12). The second change was that the left channel near Bridge 342 (fig. 13) eroded. If erosion continues there, additional flow will pass through Bridge 344. The third change was a major channel shift that directed more flow toward Bridge 339 (fig. 13) and less flow toward the bridges at Flag Point.

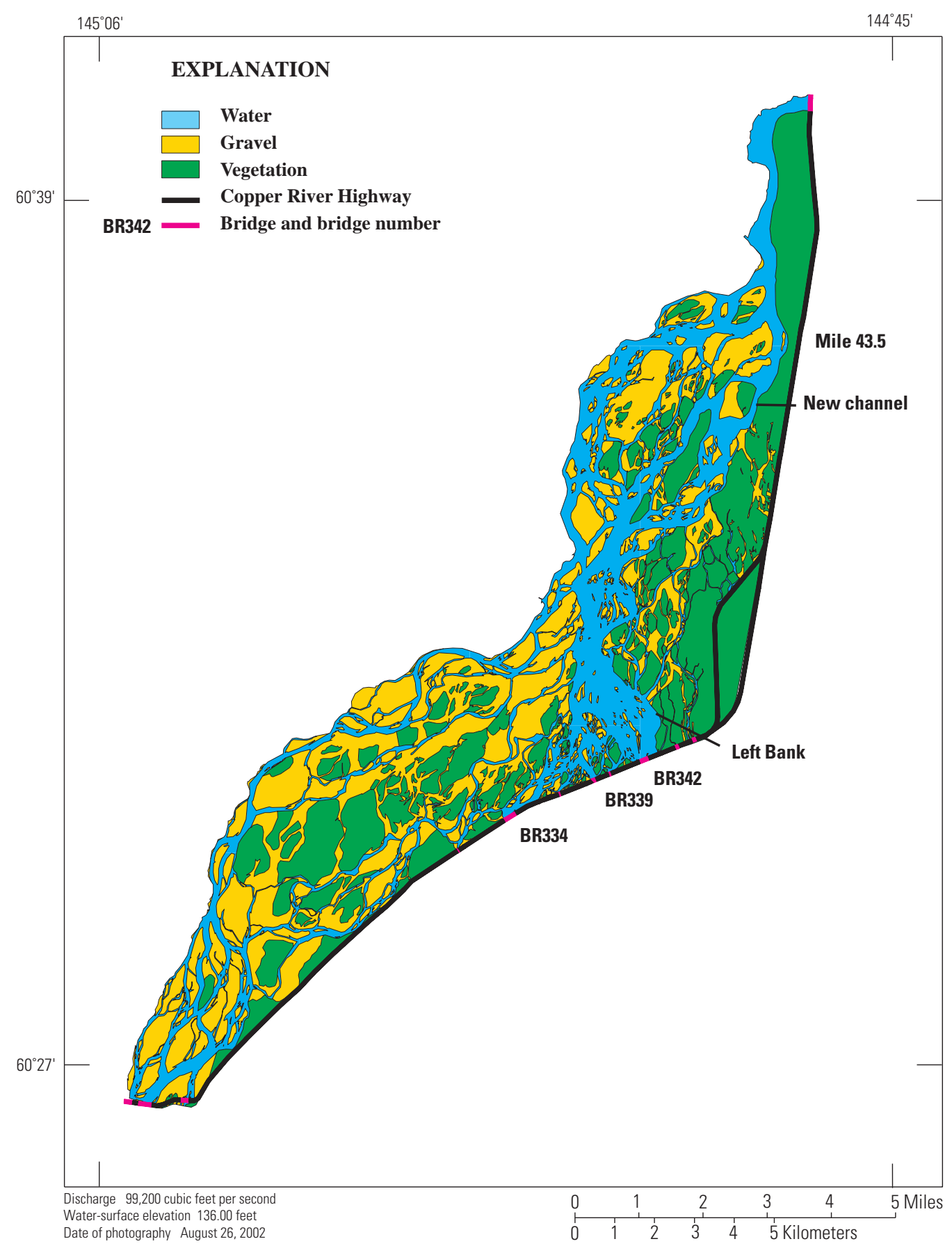

Figure 11. Lower Copper River, Alaska, based on aerial photographs taken in 2002. 


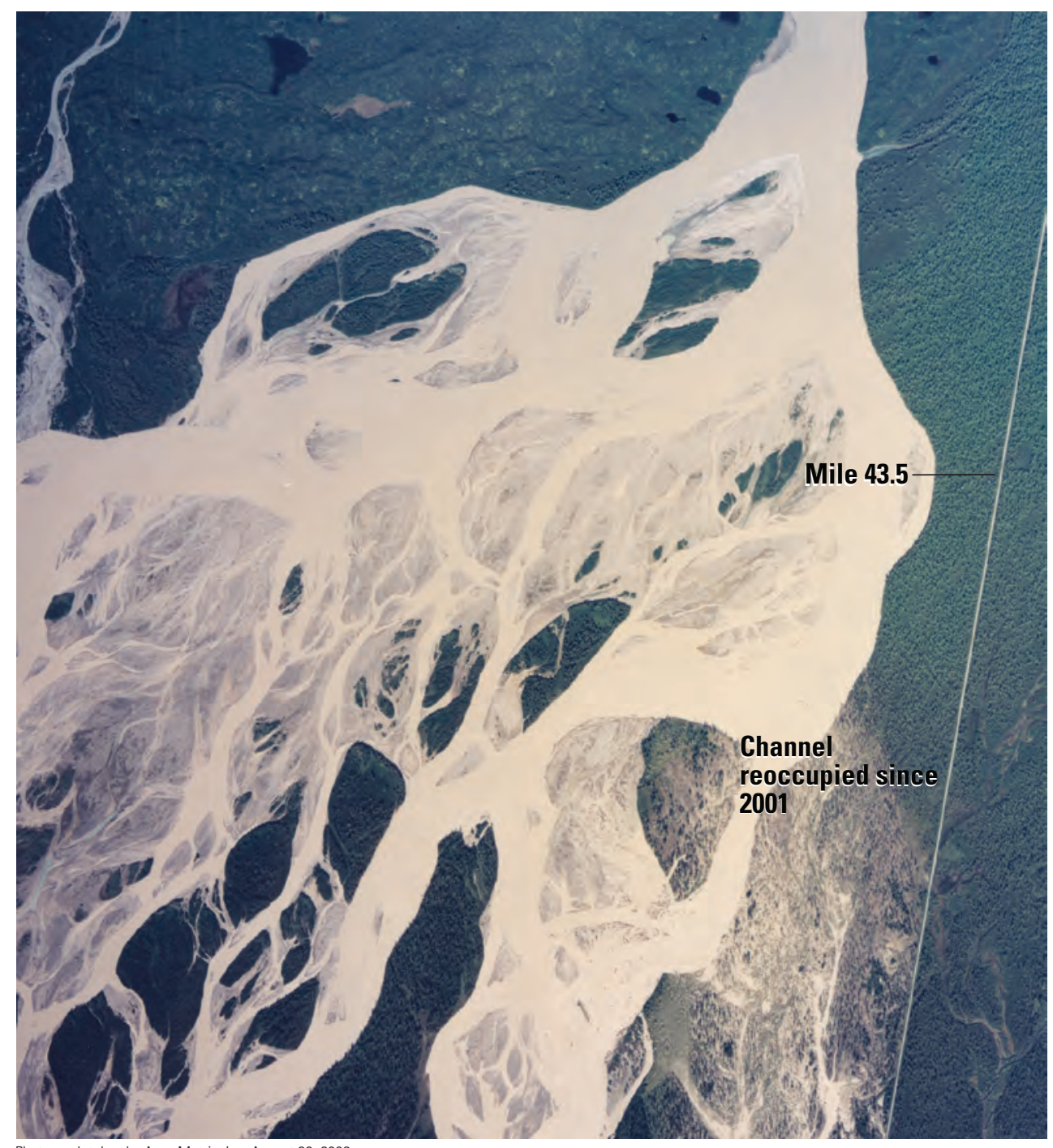

Photograph taken by Aero-Metric, Inc. August 26, 2002.

Figure 12. Area near Mile 43.5 along the lower Copper River, Alaska, 2002. 

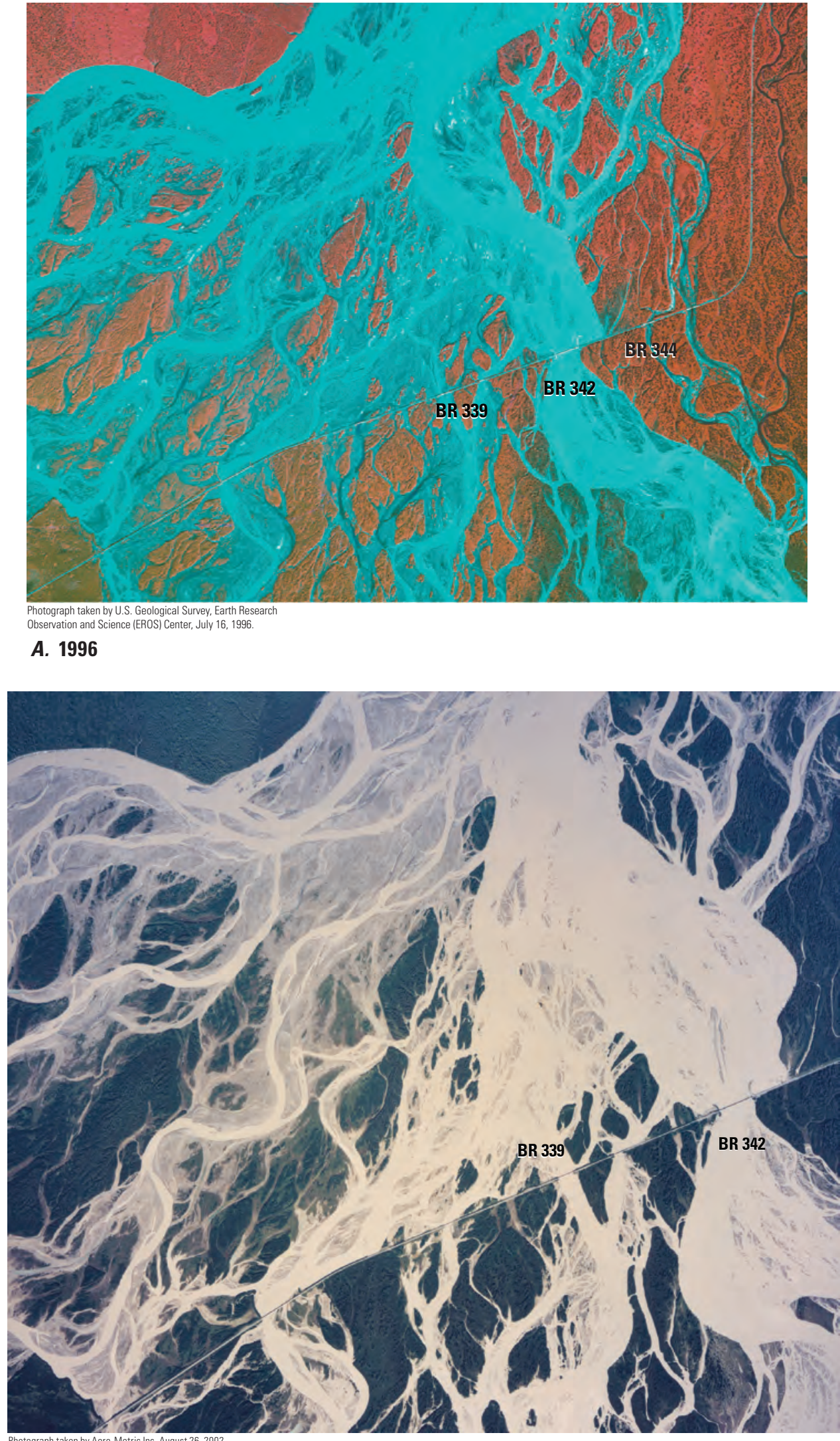

B. 2002

Figure 13. Channel change near Bridge 339 in $(A) 1996$ and (B) 2002, lower Copper River, Alaska. 


\section{Geomorphology and River Dynamics of the Lower Copper River, Alaska}

Aerial photography taken in 2006 and 2007 showed the continued erosion near Mile 43.5 of the Copper River Highway (figs. 14A, 14B). This continued erosion and channel encroachment near Mile 43.5 resulted in the inundation of the area adjacent to Mile 41 through Mile 44 during normal flow regimes (figs. 15-16). Rainfall from September 9 to 13, 2007 increased the stage of the Copper River at the Million Dollar Bridge to $144.41 \mathrm{ft}$ and this section of the highway was almost overtopped. Near Bridge 339, flow continued to erode the west approach to the bridge (fig. 17) and throughout 2006 and 2007, riprap was placed along the approach to stabilize the approach section (fig. 18).

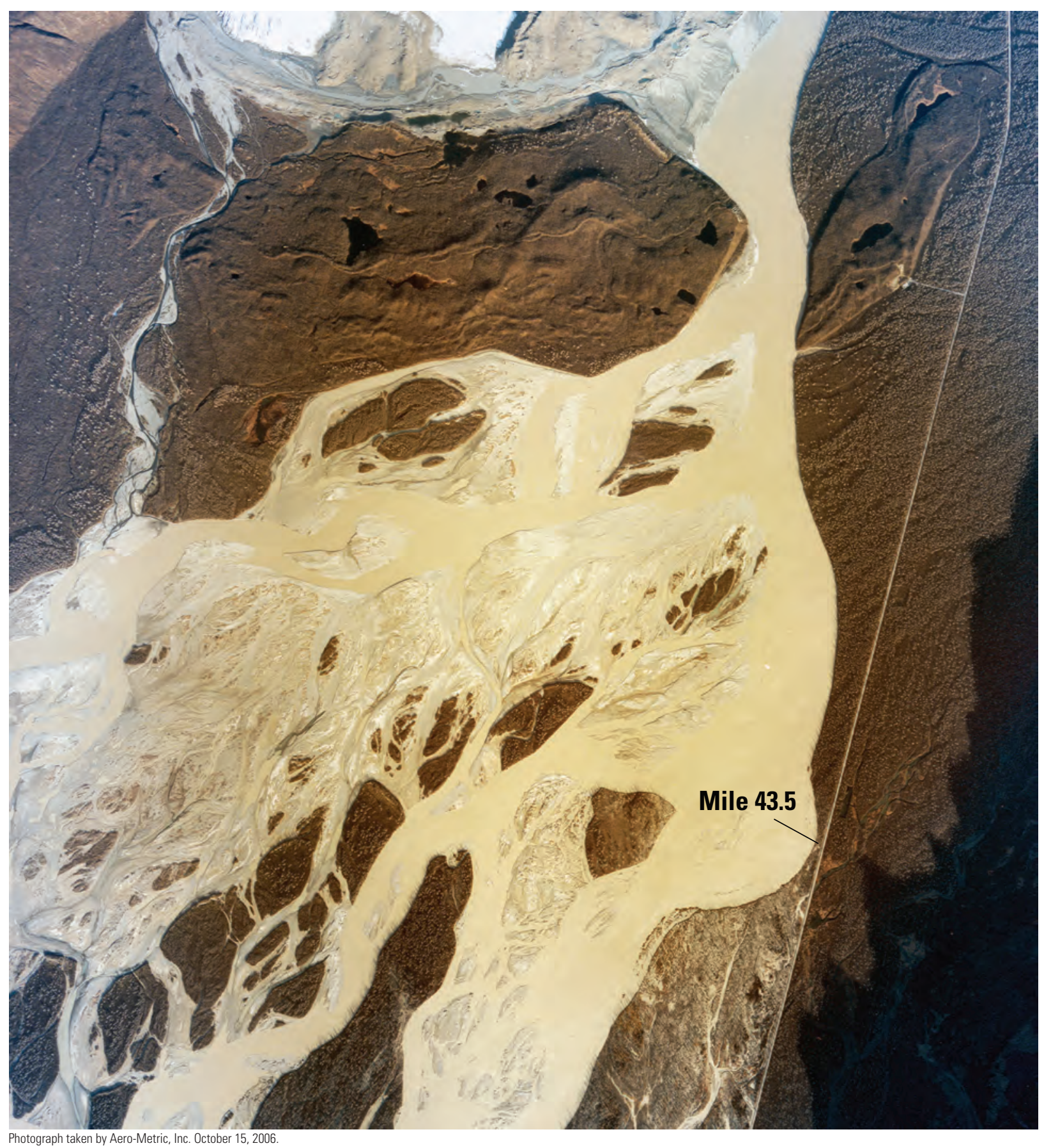

\section{A. 2006}

Figure 14. Area near Mile 43.5 in $(A) 2006$ and $(B)$ 2007, lower Copper River, Alaska. 


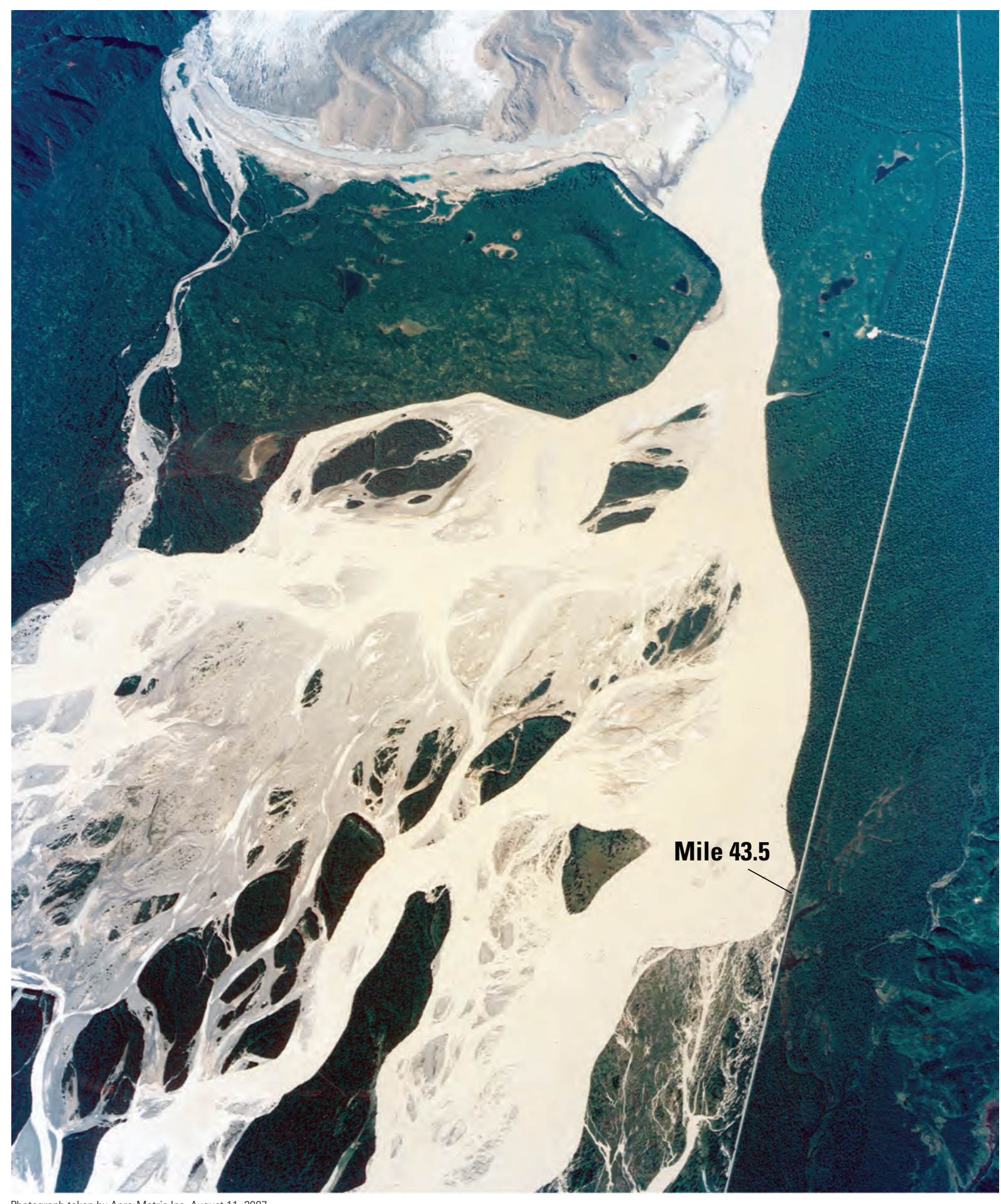

Photograph taken by Aero-Metric Inc. August 11, 2007.

\section{B. 2007}

Figure 14.-Continued. 


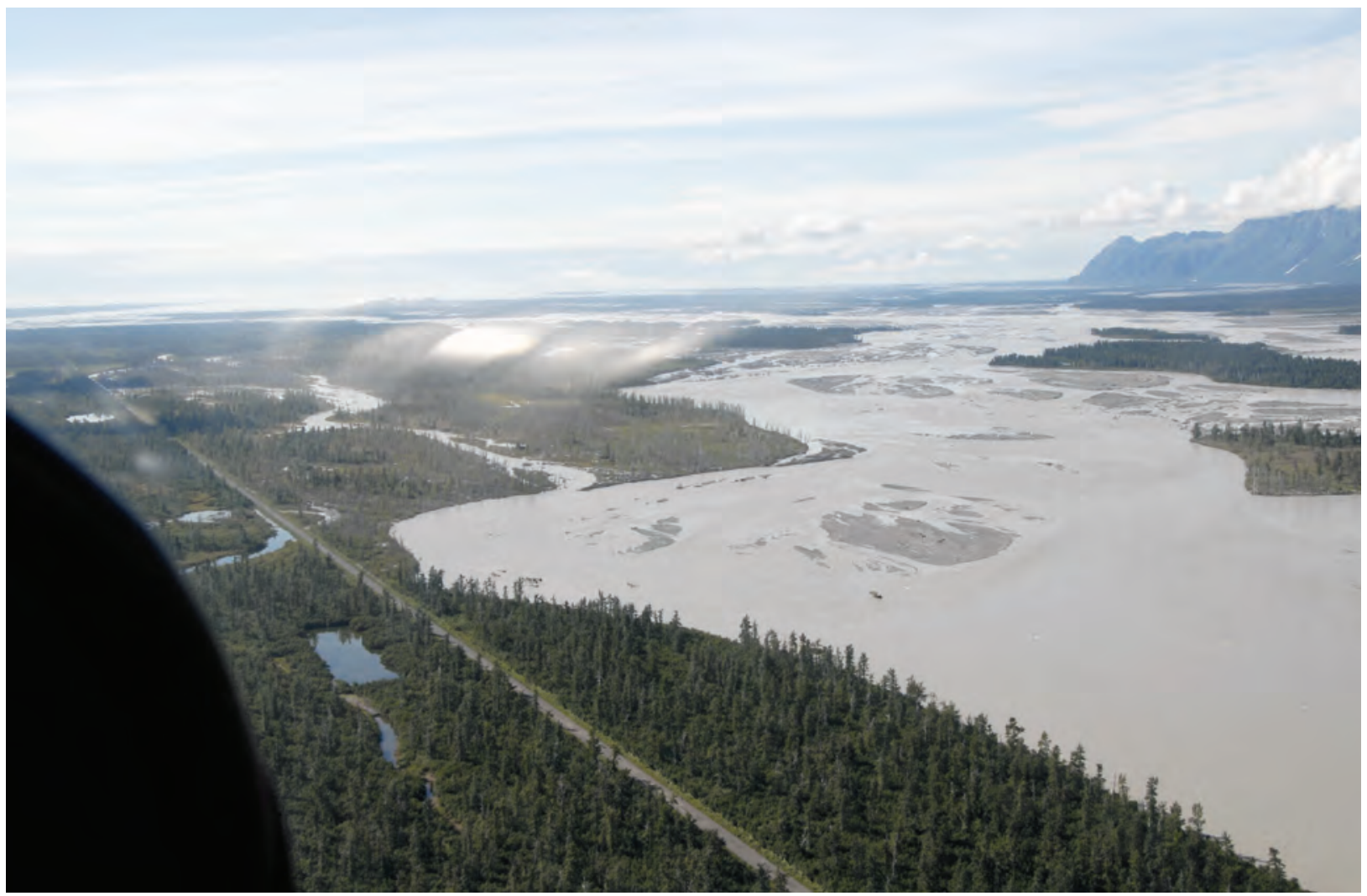

Figure 15. Copper River Highway looking downstream near Mile 45, lower Copper River, Alaska, August 30, 2007.

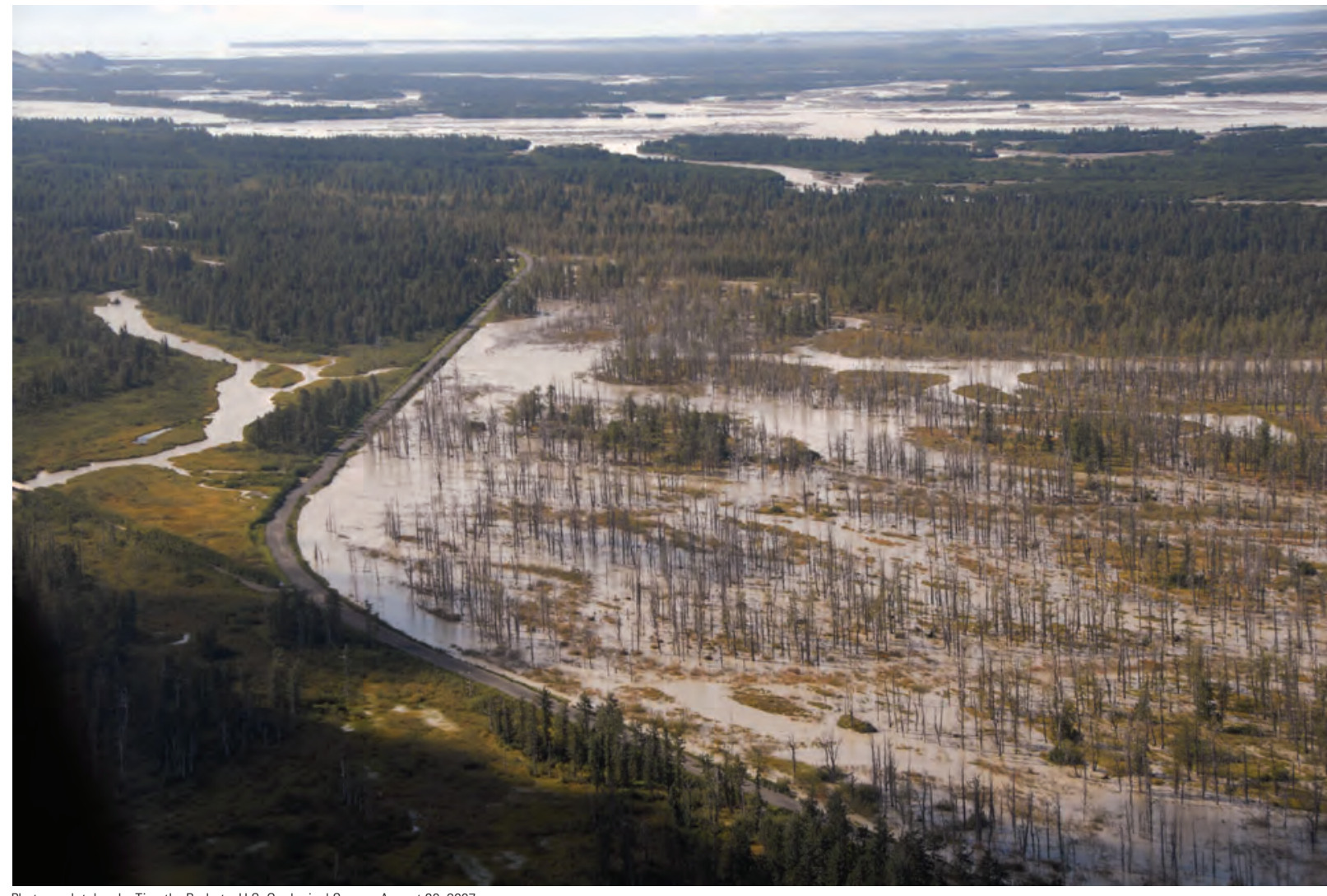

Photograph taken by Timothy Brabets, U.S. Geological Survey, August 30, 2007.

Figure 16. Copper River Highway from Mile 41 to Mile 44, lower Copper River, Alaska. 


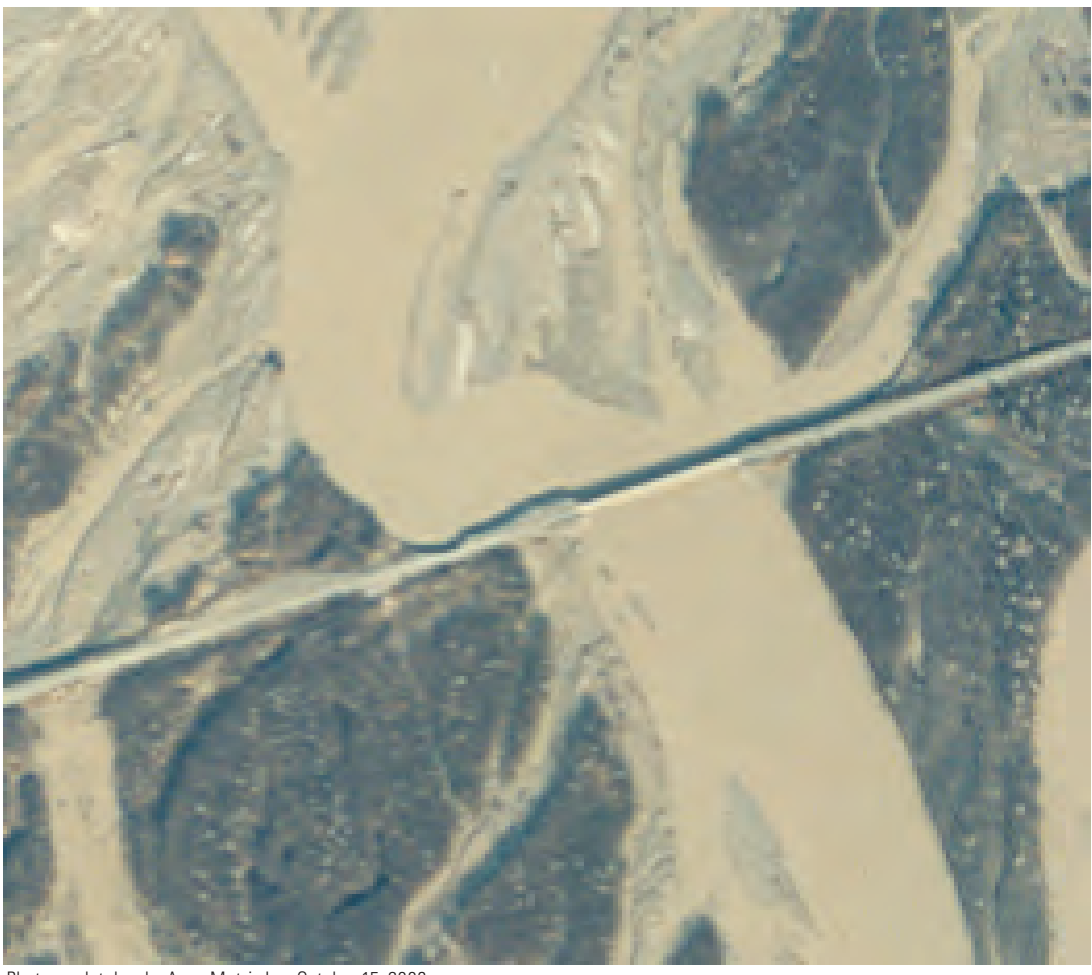

Photograph taken by Aero-Metric Inc. October 15, 2006

\section{A. 2006}

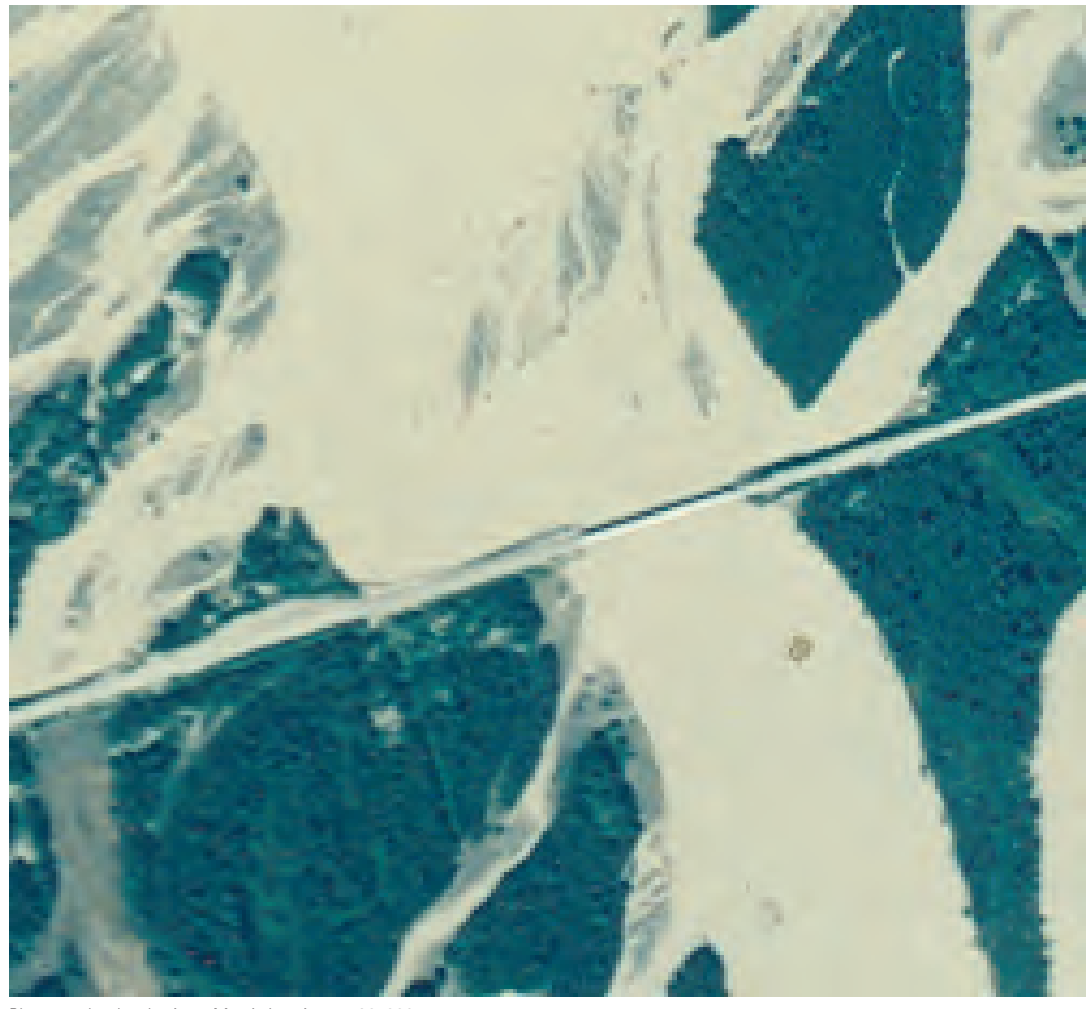

Photograph taken by Aero-Metric Inc. August 30, 2007

\section{B. 2007}

Figure 17. Area near Bridge 339 in $(A) 2006$ and $(B)$ 2007, lower Copper River, Alaska. 


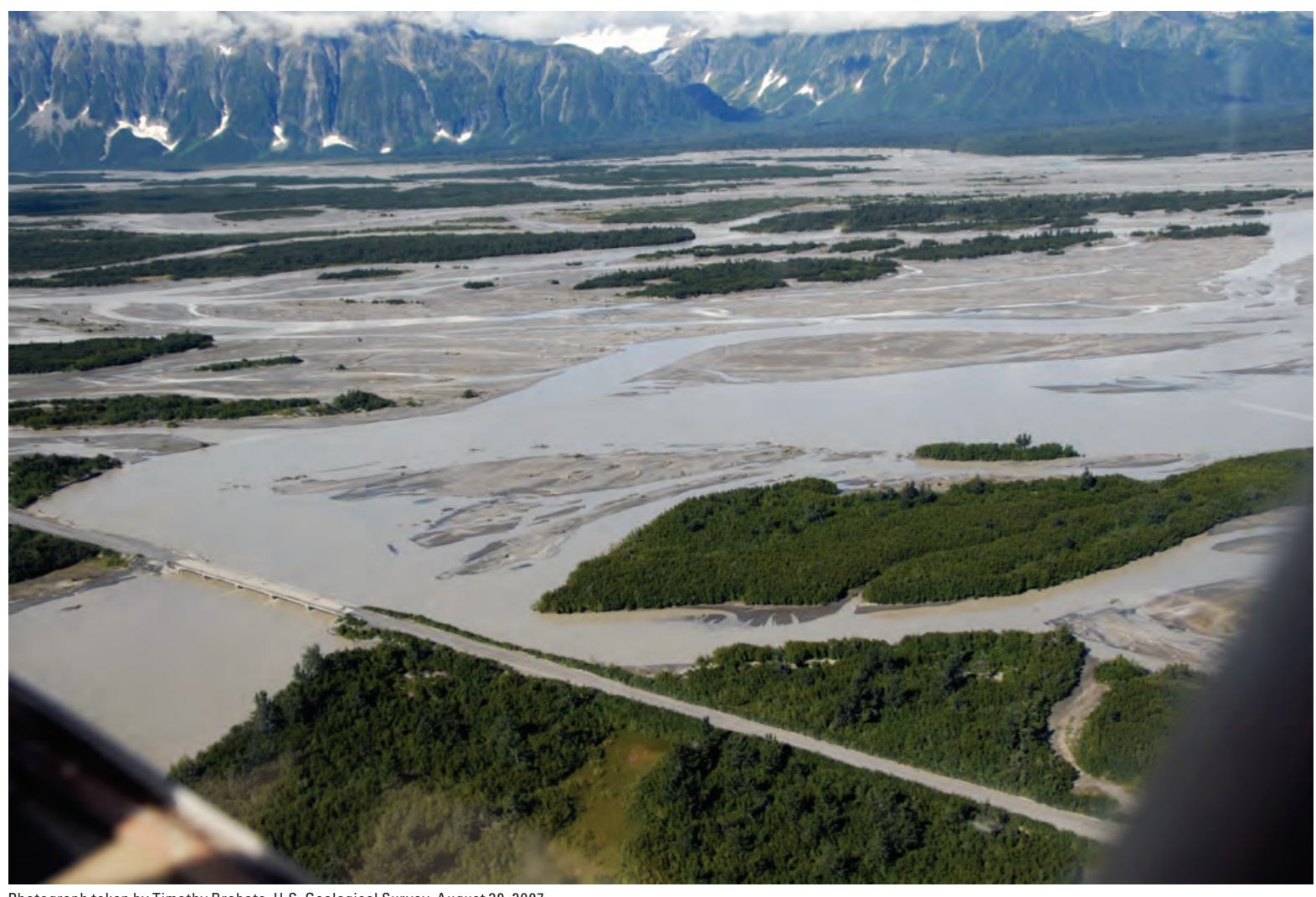

Photograph taken by Timothy Brabets, U.S. Geological Survey, August 30, 2007

Figure 18. Copper River Highway at Bridge 339, lower Copper River, Alaska.

\section{Characteristics and Trends in Flow Distribution 1996-2007}

In 1995, 50 percent of the total flow of the Copper River, as measured at the Million Dollar Bridge (USGS streamgaging station 15214000), passed through the bridges at Flag Point and approximately 50 percent passed through Bridge 342 (Brabets, 1997). The stream-gaging station at the Million Dollar Bridge was discontinued in 1995 and was reactivated in 2005. Each year, however, the Alaska Department of Fish and Game (ADF\&G) operated a sonar fish counter at the Million Dollar Bridge from approximately the middle of May to the first week in August. During the fish counting operation, ADF\&G personnel measure water-surface elevation (water stage) twice per day from the USGS wire-weight gage. Using the stage-discharge rating curve that was developed when the stream-gaging station was active and the water stage readings from ADF\&G, the general flow characteristics of the Copper River from 1996 to 2004 were determined. Because no stage data are available for August and September, rainfall records from Cordova were inspected to determine if there might have been any unusually high flows during those months. Flow records from a USGS gaging station on the Gulkana River (15200280), in the interior of the Copper River basin, were examined to identify any high-flow periods during May through September. A short history of flow conditions and the subsequent probable cause of channel changes was documented (table 1) on the basis of the water-stage records from ADF\&G from 1996 to 2004, rainfall records from Cordova, streamflow data from the Gulkana River, and information on Van Cleave Lake breakouts (Donald Carlson, Alaska Department of Transportation and Public Facilities, written commun., 2005).

Based on analyses of available data, flow conditions in the lower Copper River from 1996 to 1999 would be considered average. As noted previously, flow patterns and conditions shown in the 1996 photography were similar to those indicated in the 1991 photography. Daily discharge values at the Gulkana River ranged from average to below average, so it is unlikely that there were any floods in the upper part of the Copper River basin. In 1997, sustained (14 days) above average flow occurred at the Million Dollar Bridge in early July (table 1), reflecting contributions to the river from snowmelt, glacier ice melt, and possibly a breakout of Van Cleve Lake. Flow was above average for 5 days in 1998, but flows in 1999 appeared to be average. A breakout of Van Cleve Lake occurred in 2000 (Donald Carlson, Alaska Department of Transportation and Public Facilities,, written commun., 2005), resulting in sustained above average flow for 2 weeks. However, peak stage readings by ADF\&G (table 1) from the wire-weight gage were similar to those from 1996 to 1999. 
Table 1. Summary of flow conditions at the Million Dollar Bridge, lower Copper River, Alaska, water years 1996-2007.

[Bridge locations are shown in figure 3. Summary is based on water-surface elevation readings from Alaska Department of Fish and Game for late May, June, July, and early August. Documentation of Van Cleve Lake breakouts for 2000 and 2003 provided by Donald Carlson of Alaska Department of Transportation and Public Facilities; Abbreviations ft, foot; $\mathrm{ft}^{3} / \mathrm{s}$, cubic foot per second]

\begin{tabular}{|c|c|c|c|}
\hline $\begin{array}{l}\text { Water } \\
\text { year }\end{array}$ & $\begin{array}{c}\text { Peak } \\
\text { stage } \\
\text { (ft) }\end{array}$ & $\begin{array}{l}\text { Estimated } \\
\text { peak } \\
\text { discharge } \\
\left(\mathrm{ft}^{3} / \mathrm{s}\right)\end{array}$ & Remarks \\
\hline 1996 & 141.77 & 180,000 & $\begin{array}{l}\text { No sustained high flow; precipitation at Gulkana and Cordova below normal } \\
\text { Aerial photograph taken; no major channel changes; Gulkana River flow normal }\end{array}$ \\
\hline 1997 & 143.50 & 209,000 & Sustained high flow for 2 weeks, possible Van Cleve breakout, precipitation normal, Gulkana River flow normal \\
\hline 1999 & 142.50 & 192,000 & Precipitation below normal, normal fluctuations of the Copper River flow, Gulkana River flow normal \\
\hline 2000 & 142.50 & 192,000 & $\begin{array}{l}\text { Sustained high flow for } 2 \text { weeks, Van Cleve Lake breakout (documented), below average precipitation at Gulkana } \\
\text { and Cordova, Gulkana River flow normal }\end{array}$ \\
\hline 2001 & 145.14 & 239,000 & Sustained high flow for 2 weeks, road flooded, additional culverts installed \\
\hline 2004 & 146.19 & 260,000 & $\begin{array}{l}\text { Above normal precipitation for Cordova for July and September. Span raised on the Million Dollar Bridge. New } \\
\text { rating curve. }\end{array}$ \\
\hline 2005 & 145.13 & 287,000 & Normal fluctuations of the Copper River flow \\
\hline 2006 & 146.18 & 311,000 & \\
\hline \multirow[t]{2}{*}{2007} & 151.33 & 444,000 & Large flood, October 2006, recurrence interval estimated at approximately 80 years \\
\hline & 144.41 & 271,000 & \\
\hline
\end{tabular}

From May until about mid-July 2001, flow and stage characteristics were similar to those recorded during the same months in 1996-2000. In late July, most likely due to local rainfall, the stage of the Copper River at the Million Dollar Bridge rose to $145.14 \mathrm{ft}$, the highest stage documented by ADF\&G during 1996-2001. Because there are no bridges or culverts from Mile 40 to Mile 43.5 of the Copper River Highway, the roadway/road embankment acted as a dike and was eventually overtopped. To lower the water surface, eight culverts were installed along this section of the roadway. From 2001 to 2004, stage and likely flow were higher relative to the conditions in the late 1990s. In 2003, another breakout of Van Cleve Lake was documented.

As part of the ADOT\&PF and USGS study, the gaging station at the Million Dollar Bridge (USGS ID 15214000) was reactivated in 2005; therefore, stage and streamflow data are available for the entire runoff season (mid-May to early October) for 2005-08 (ig. 19). In May and June 2005, average daily discharge was the highest for the period of streamflow record as a result of melting and runoff from a deep seasonal snowpack in the Copper River basin.
The instantaneous peak discharge, 287,000 ft $3 / \mathrm{s}$, has a 50 percent chance of occurrence. In 2006, there were multiple periods of high flow, and in May, an ice jam caused a washout at about Mile 41 of the Copper River Highway. Flow conditions were average until a storm in mid-August caused a rapid increase in stage of the Copper River. The peak discharge during this storm, 311,000 ft $3 / \mathrm{s}$, had approximately a 25 percent chance of occurrence. Flow then steadily declined until a large storm struck south central Alaska in October. The stage of the river rose quickly to about $151.33 \mathrm{ft}$ (fig. 19). The peak discharge for this storm, 444,000 $\mathrm{ft}^{3} / \mathrm{s}$, was estimated to have only a 1 to 1.5 percent chance of occurrence based on an analysis of peak discharges from 1950 to 1995 and 2005 to 2007. Flow conditions on the Copper River were average in 2007. One storm in early September rapidly raised the stage of the river to $144.41 \mathrm{ft}$, resulting in a peak discharge of $271,000 \mathrm{ft}^{3} / \mathrm{s}$, which has approximately a 50 percent chance of occurrence. Discharge on the Copper River was below average in water year 2008, primarily due to a cool summer in south central Alaska, resulting in reduced glacier melting. 


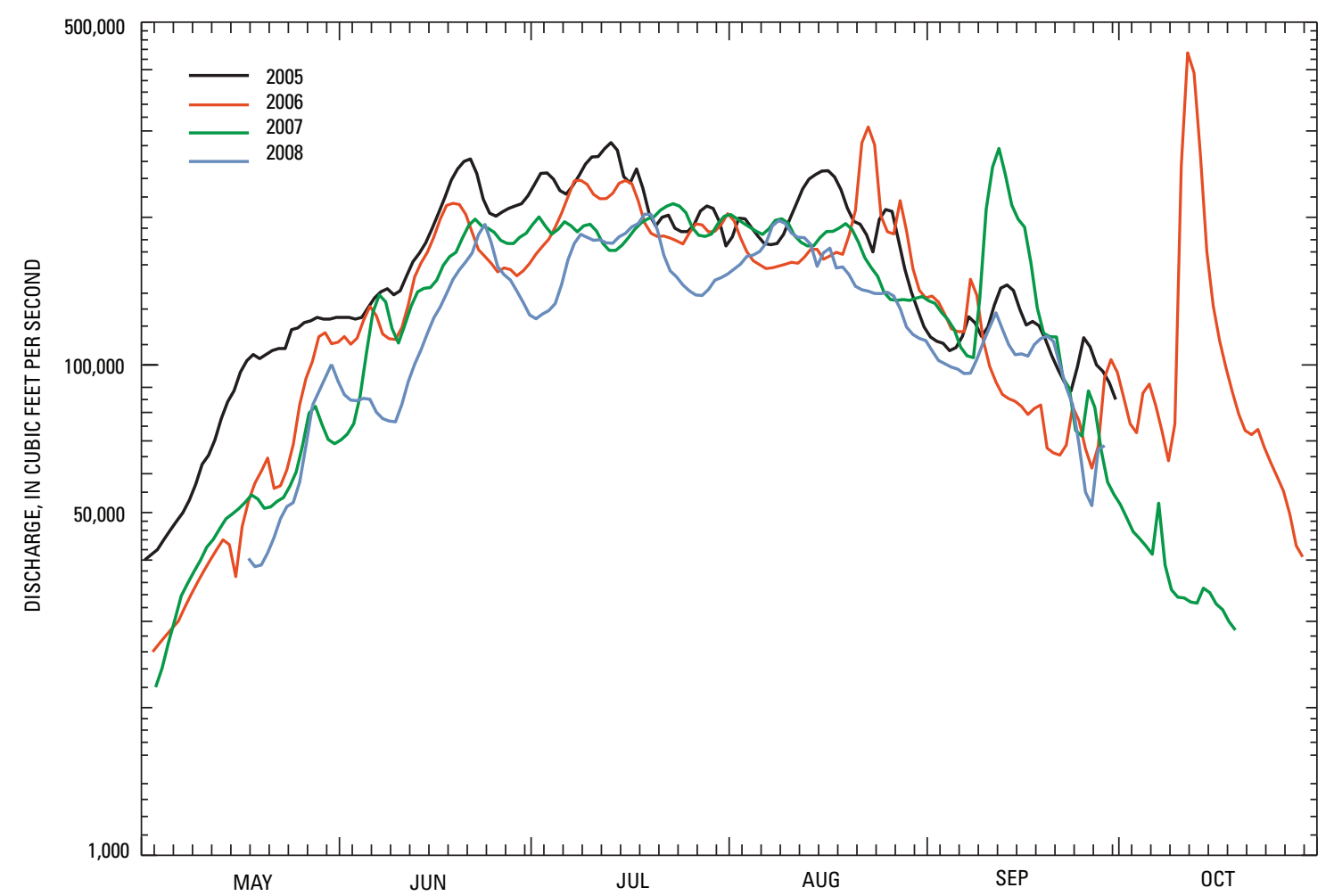

Figure 19. Discharge of the lower Copper River at the Million Dollar Bridge, lower Copper River, Alaska, 2005-08.

For the previous study of the lower Copper River (Brabets, 1997), a series of discharge measurements were made between 1991 and 1995 at the bridges along the Copper River Highway from Flag Point to the Million Dollar Bridge. These discharge measurements were made to determine the percentage of the total flow at the Million Dollar Bridge passing through each downstream bridge. If the percentages of flow (at the individual bridges) were to change, this would indicate a possible channel shift upstream of the respective bridge. These series of measurements were repeated in 2005-07 to determine if the percentages of flow had changed significantly since 1991-95.

During 1991-95, flow was split virtually equally between the bridges at Flag Point and Bridge 342. Flow at Bridge 339 ranged from 0 to 6 percent $\left(0 \mathrm{ft}^{3} / \mathrm{s}\right.$ to $\left.14,600 \mathrm{ft}^{3} / \mathrm{s}\right)$ of the flow at the Million Dollar Bridge (Brabets, 1997). From 2005 to 2007, however, the percent flow through Bridge 339 increased, and ranged from 0 to 24 percent $\left(0 \mathrm{ft}^{3} / \mathrm{s}\right.$ to $\left.32,500 \mathrm{ft}^{3} / \mathrm{s}\right)$ of the discharge (tables 2 and $\underline{3}$ ), At Bridge 342, discharge now (2008) exceeds 50 percent of the total flow (fig. 20) at discharges less than $271,000 \mathrm{ft}^{3} / \mathrm{s}$ (measured at USGS station 15214000) and has been as high as 100 percent at discharges less than 50,000 ft $3 / \mathrm{s}$ (measured at USGS station 15214000). Increases in flow at these two bridges indicate channel changes. At discharges less than $75,000 \mathrm{ft}^{3} / \mathrm{s}$ (measured at USGS station 15214000) only about 5 percent of the total flow of the Copper River now passes through the bridges at Flag Point (table 3). 
Table 2. Discharge at bridges along the Copper River Highway, lower Copper River, Alaska, 2005-07.

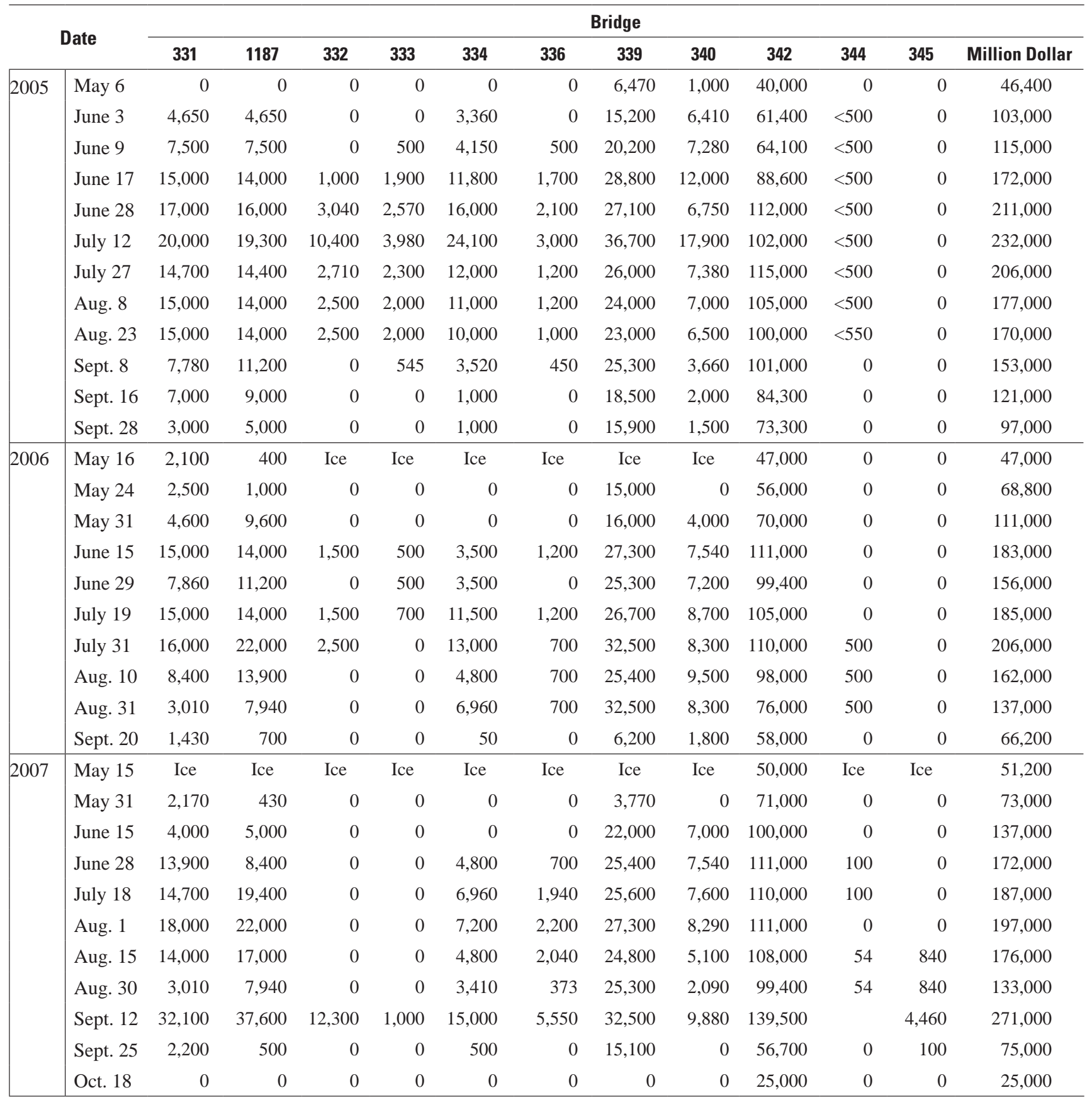


Table 3. Percentage of discharge at selected bridges along the Copper River Highway, lower Copper River, Alaska, $2005-07$.

\begin{tabular}{|c|c|c|c|c|c|c|c|c|c|c|c|c|c|c|c|}
\hline & \multirow{2}{*}{ Date } & \multicolumn{5}{|c|}{ Flag Point Bridges } & \multicolumn{8}{|c|}{ Bridges 336, 339, 340, 342, and Million Dollar } & \multirow[b]{2}{*}{$\begin{array}{c}\text { Million } \\
\text { Dollar }\end{array}$} \\
\hline & & 331 & 1187 & 332 & Total & $\begin{array}{c}\text { Percent } \\
\text { Total }\end{array}$ & 336 & $\begin{array}{c}\text { Percent } \\
\text { Total }\end{array}$ & 339 & $\begin{array}{c}\text { Percent } \\
\text { Total }\end{array}$ & 340 & $\begin{array}{c}\text { Percent } \\
\text { Total }\end{array}$ & 342 & $\begin{array}{c}\text { Percent } \\
\text { Total }\end{array}$ & \\
\hline \multirow[t]{12}{*}{2005} & May 6 & 0 & 0 & 0 & 0 & 0 & 0 & 0.0 & 6,470 & 14 & 1,000 & 2.2 & 40,000 & 86 & 46,400 \\
\hline & June 3 & 4,650 & 4,650 & 0 & 9,300 & 9 & 0 & .0 & 15,200 & 15 & 6,410 & 6.2 & 61,400 & 60 & 103,000 \\
\hline & June 9 & 7,500 & 7,500 & 0 & 15,000 & 13 & 500 & .4 & 20,200 & 18 & 7,280 & 6.3 & 64,100 & 56 & 115,000 \\
\hline & June 17 & 15,000 & 14,000 & 1,000 & 30,000 & 17 & 1,700 & 1.0 & 28,800 & 17 & 12,000 & 7.0 & 88,600 & 52 & 172,000 \\
\hline & June 28 & 17,000 & 16,000 & 3,040 & 36,040 & 17 & 2,100 & 1.0 & 27,100 & 13 & 6,750 & 3.2 & 112,000 & 53 & 211,000 \\
\hline & July 12 & 20,000 & 19,300 & 10,400 & 49,700 & 21 & 3,000 & 1.3 & 36,700 & 16 & 17,900 & 7.7 & 102,000 & 44 & 232,000 \\
\hline & July 27 & 14,700 & 14,400 & 2,710 & 31,810 & 15 & 1,200 & .6 & 26,000 & 13 & 7,380 & 3.6 & 115,000 & 56 & 206,000 \\
\hline & Aug. 8 & 15,000 & 14,000 & 2,500 & 31,500 & 18 & 1,200 & .7 & 24,000 & 14 & 7,000 & 4.0 & 105,000 & 59 & 177,000 \\
\hline & Aug. 23 & 15,000 & 14,000 & 2,500 & 31,500 & 19 & 1,000 & .6 & 23,000 & 14 & 6,500 & 3.8 & 100,000 & 59 & 170,000 \\
\hline & Sept. 8 & 7,780 & 11,200 & 0 & 18,980 & 12 & 450 & .3 & 25,300 & 17 & 3,660 & 2.4 & 101,000 & 66 & 153,000 \\
\hline & Sept. 16 & 7,000 & 9,000 & 0 & 16,000 & 13 & 0 & .0 & 18,500 & 15 & 2,000 & 1.7 & 84,300 & 70 & 121,000 \\
\hline & Sept. 28 & 3,000 & 5,000 & 0 & 8,000 & 8 & 0 & .0 & 15,900 & 16 & 1,500 & 1.5 & 73,300 & 76 & 97,000 \\
\hline \multirow[t]{10}{*}{2006} & May 16 & 2,100 & 400 & Ice & 2,500 & 5 & Ice & & Ice & & Ice & & 47,000 & 100 & 47,000 \\
\hline & May 24 & 2,500 & 1,000 & 0 & 3,500 & 5 & 0 & 0.0 & 15,000 & 22 & 0 & 0.0 & 56,000 & 81 & 68,800 \\
\hline & May 31 & 4,600 & 9,600 & 0 & 14,200 & 13 & 0 & .0 & 16,000 & 14 & 4,000 & 3.6 & 70,000 & 63 & 111,000 \\
\hline & June 15 & 15,000 & 14,000 & 1,500 & 30,500 & 17 & 1,200 & .7 & 27,300 & 15 & 7,540 & 4.1 & 111,000 & 61 & 183,000 \\
\hline & June 29 & 7,860 & 11,200 & 0 & 19,060 & 12 & 0 & .0 & 25,300 & 16 & 7,200 & 4.6 & 99,400 & 64 & 156,000 \\
\hline & July 19 & 15,000 & 14,000 & 1,500 & 30,500 & 16 & 1,200 & .6 & 26,700 & 14 & 8,700 & 4.7 & 105,000 & 57 & 185,000 \\
\hline & July 31 & 16,000 & 22,000 & 2,500 & 40,500 & 20 & 700 & .3 & 32,500 & 16 & 8,300 & 4.0 & 110,000 & 53 & 206,000 \\
\hline & Aug. 10 & 8,400 & 13,900 & 0 & 22,300 & 14 & 700 & .4 & 25,400 & 16 & 9,500 & 5.9 & 98,000 & 60 & 162,000 \\
\hline & Aug. 31 & 3,010 & 7,940 & 0 & 10,950 & 8 & 700 & .5 & 32,500 & 24 & 8,300 & 6.1 & 76,000 & 55 & 137,000 \\
\hline & Sept. 20 & 1,430 & 700 & 0 & 2,130 & 3 & 0 & .0 & 6,200 & 9 & 1,800 & 2.7 & 58,000 & 88 & 66,200 \\
\hline \multirow[t]{11}{*}{2007} & May 15 & Ice & Ice & Ice & 0 & 0 & Ice & & Ice & & Ice & & 50,000 & 98 & 51,200 \\
\hline & May 31 & 2,170 & 430 & 0 & 2,600 & 4 & 0 & 0.0 & 3,770 & 5 & 0 & 0.0 & 71,000 & 97 & 73,000 \\
\hline & June 15 & 4,000 & 5,000 & 0 & 9,000 & 7 & 0 & .0 & 22,000 & 16 & 7,000 & 5.1 & 100,000 & 73 & 137,000 \\
\hline & June 28 & 13,900 & 8,400 & 0 & 22,300 & 13 & 700 & .4 & 25,400 & 15 & 7,540 & 4.4 & 111,000 & 65 & 172,000 \\
\hline & July 18 & 14,700 & 19,400 & 0 & 34,100 & 18 & 1,940 & 1.0 & 25,600 & 14 & 7,600 & 4.1 & 110,000 & 59 & 187,000 \\
\hline & Aug. 1 & 18,000 & 22,000 & 0 & 40,000 & 20 & 2,200 & 1.1 & 27,300 & 14 & 8,290 & 4.2 & 111,000 & 56 & 197,000 \\
\hline & Aug. 15 & 14,000 & 17,000 & 0 & 31,000 & 18 & 2,040 & 1.2 & 24,800 & 14 & 5,100 & 2.9 & 108,000 & 61 & 176,000 \\
\hline & Aug. 30 & 3,010 & 7,940 & 0 & 10,950 & 8 & 373 & .3 & 25,300 & 19 & 2,090 & 1.6 & 99,400 & 75 & 133,000 \\
\hline & Sept. 12 & 32,100 & 37,600 & 12,300 & 82,000 & 30 & 5,550 & 2.0 & 32,500 & 12 & 9,880 & 3.6 & 139,500 & 51 & 271,000 \\
\hline & Sept. 25 & 2,200 & 500 & 0 & 2,700 & 4 & 0 & 0 & 15,100 & 20 & 0 & .0 & 56,700 & 76 & 75,000 \\
\hline & Oct. 18 & 0 & 0 & 0 & 0 & 0 & 0 & 0 & 0 & 0 & 0 & .0 & 25,000 & 100 & 25,000 \\
\hline
\end{tabular}




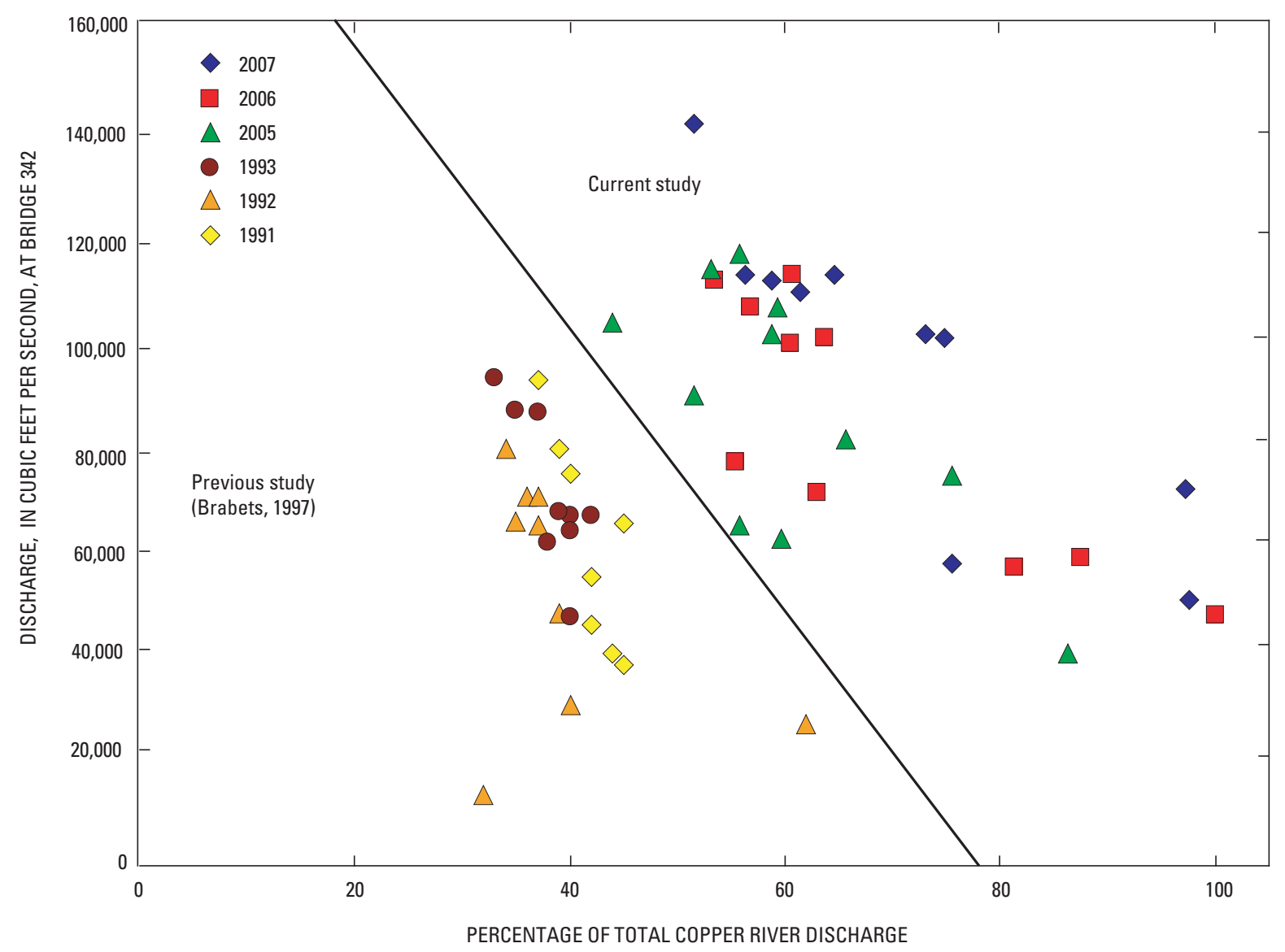

Figure 20. Percentage of total discharge at the Million Dollar Bridge that flows under Bridge 342, lower Copper River, Alaska, 1991-93 and 2005-07.

\section{Multi-Dimensional Surface Water Modeling System}

The USGS Multi-Dimensional Surface Water Modeling System (MD_SWMS) (McDonald and others, 2005) was used in this study to simulate water-surface elevation and velocity, and to compute the critical bed shear stress from the predicted velocity at two locations in the lower Copper River: at Bridge 339 and near Mile 43.5 (fig. 21). The current hydraulic conditions at both areas will require continued maintenance by ADOT\&PF unless permanent solutions can be found. Because the hydraulic conditions at these two sites are complex, MD_SWMS was used to (1) gain a better understanding of the hydraulic conditions, and (2) assess whether improvements (here called "betterments") such as guide banks or bridge extensions would resolve the problems created by (or posed by) scour and erosion.

MD_SWMS is a generic Graphical User Interface (GUI) developed by the USGS (McDonald and others, 2001) for hydrodynamic models. FaSTMECH, a computational model within MD_SWMS that also was developed by the USGS (Nelson and McDonald, 1997), includes a 2-dimensional, vertically averaged model and a sub-model that calculates vertical distribution of the primary velocity and the secondary flow about the vertically averaged flow. This so-called 2.5-dimensional approach has been shown to adequately simulate the velocity field and bed shear stress, without the complexity of a fully 3-dimensional model.

Minimum data requirements for the model include a digital elevation model (DEM) of the area of interest, channel geometry, streamflow at the upstream boundary, and watersurface elevation at the downstream boundary. The primary means of constructing the DEM was using Light detection and Ranging (LIDAR) data collected in June 2005. The physical assumptions of the model are that flow is steady, incompressible, and hydrostatic (vertical accelerations are neglected), and that turbulence is adequately accounted for by relating Reynolds stresses to shear using an isotropic eddy viscosity (Nelson and others, 2003). 



Photograph taken by Aero-Metric, October 15, 2006

MAPEXPLANATION

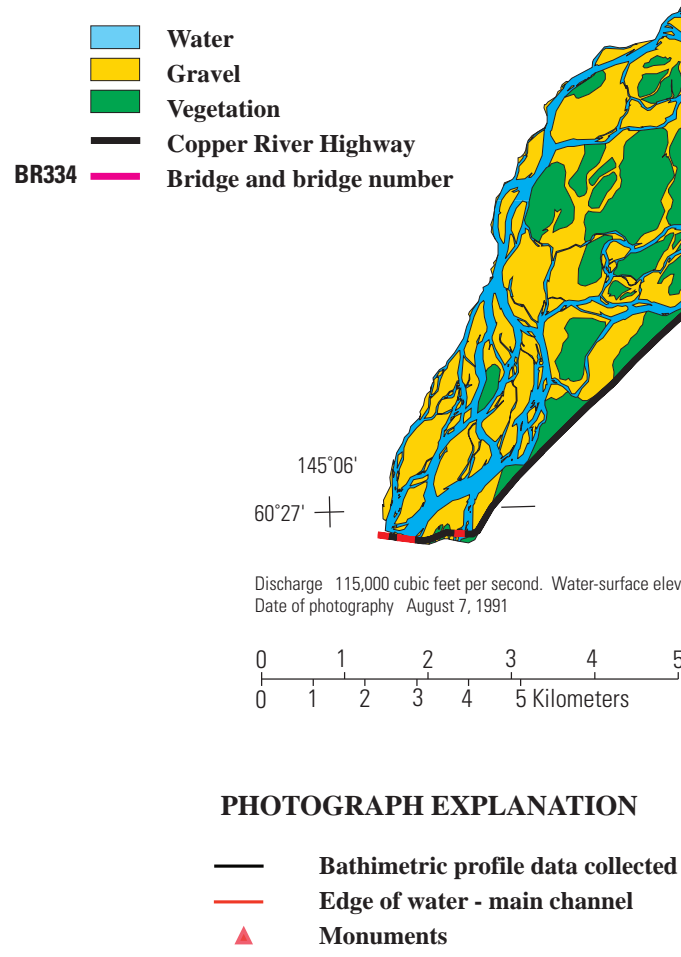

5 Miles 


\section{Computational Grid and Bathymetric Interpolation}

The computational grid used in FaSTMECH is a curvilinear orthogonal coordinate system with a user-defined centerline, defined interactively to approximate the mean flow streamline of the modeled reach (Nelson and others, 2003). The topography is mapped to the coordinates of the computational grid through a nearest-neighbor method. Model coordinates (easting and northing) are based on the North American Datum 1983 (NAD 83), Alaska Universal Transverse Mercator projection, and elevations are based on the North American Vertical Datum 1988 (NAVD 88).

The computational grid for the Bridge 339 area begins about $2 \mathrm{mi}$ above the bridge and ends about $1 / 2 \mathrm{mi}$ below the bridge (fig. 21). The grid area was selected so that possible betterments such as guide banks or increasing the length of Bridge 339 could be placed within the grid. The computational grid for the Mile 43.5 area begins downstream of Childs Glacier to just downstream of Goodwin Glacier (fig. 21). The grid area was selected because one possible betterment is to place a diversion dike upstream of Mile 43.5 to divert channels of the Copper River to the west. For the Bridge 339 area, water-surface elevations were measured at the bridge and determined from the LIDAR data for the upper and lower boundaries of the computational grid. For the Mile 43.5 area, water-surface elevations were measured at the upper and lower boundaries.

The most important input to MD_SWMS is an accurate digital elevation model (DEM) of the area of interest. In both grid areas, there is constant scour and fill, and channels are continuously shifting. Thus, a DEM based on data collected in one year may not be as accurate the following year. However, we feel reasonably good DEMs for both grid areas were created on the basis of data from several sources: LIDAR data collected in June 2005, channel bathymetry measured in June 2006 using a single beam fathometer, channel bathymetry measured in August 2006 and again in June 2007 using a multi-beam fathometer, and acoustic Doppler current profiler (ADCP) readings taken in 2006 and 2007 (fig. 21).

For the Bridge 339 area, the bathymetry data and the ADCP data were combined into one file to construct the DEM of the main channel to Bridge 339 (fig. 21) using an ARC GIS procedure called POINTINTERP. The POINTINTERP function interpolates a grid from a set of points using a specified neighborhood based on the inverse distance weighted interpolation technique. A grid cell size of 16.4 by $16.4 \mathrm{ft}$ ( 5 by $5 \mathrm{~m}$ ) was used. The grid created by POINTINTERP was then output to an ASCII file. Using tools available in MD_SWMS, the data that represents the main channel to Bridge 339 was deleted from the LIDAR data and replaced by the data that represents the channel created by the POINTINTERP procedure.
Flood-plain elevations in the Bridge 339 area were set to the elevations of the vegetated islands. Gravel bars and small channels are scattered throughout the approach section leading to Bridge 339 (fig. 21) but only a small percentage of the river's total flow goes through these channels at high stages. Thus, the runs of MD_SWMS were simplified by modeling only the main channel. The final computational grid was 5,100 ft (1,555 m) long (311 nodes) in the downstream direction and 1,640 ft (500 m) wide (101 nodes) in the crosssection direction, forming an approximately $5,000 \mathrm{ft}(1,500 \mathrm{~m})$ by $1,600 \mathrm{ft}(500 \mathrm{~m})$ grid $\left(0.29 \mathrm{mi}^{2}\right)$ consisting of 31,400 cells spaced every $16.4 \mathrm{ft}(5 \mathrm{~m})$ in both the downstream and crossstream direction.

The Mile 43.5 area $\left(13.5 \mathrm{mi}^{2}\right)$ is much larger than the Bridge 339 area (fig. 21) and thus a larger cell size; 82 by $82 \mathrm{ft}$ ( 25 by $25 \mathrm{~m}$ ) was selected when using MD_SWMS. For this area, most of the DEM consists of the 2005 LIDAR data. The only channel change since the LIDAR data were collected is near Mile 43.5. The channels were deleted from the LIDAR data and replaced by the measured bathymetry data using tools available in MD_SWMS (fig. 21). Bathymetry data could not be collected at the upstream boundary due to unsafe conditions and thus conditions and values were estimated. The computational grid was $11,500 \mathrm{ft}(3,525 \mathrm{~m})$ in length (141 nodes) in the downstream direction and 32,800 ft $(10,000 \mathrm{~m})$ in width (451 nodes) in the cross-section direction, forming an approximately 2 by $6 \mathrm{mi}(3,500$ by $10,000 \mathrm{~m})$ grid consisting of 63,591 cells spaced every $82 \mathrm{ft}(25 \mathrm{~m})$ in both the downstream and cross-stream direction.

\section{Model Calibration and Boundary Conditions}

Calibration is the process of adjusting initial model input parameters within reasonable limits to obtain the best fit of the simulation results to measured values. This process involves repeatedly adjusting a parameter, running the model, and inspecting differences between model simulation results and measured values, with the objective of minimizing these differences.

The drag coefficient was adjusted until the simulated water-surface slope through the modeling reach reproduced as closely as possible the measured water surface. Physically, this process is equivalent to ensuring that the roughness value used in MD_SWMS accurately simulates the head loss in the channel over long reaches. Because the downstream watersurface elevation was set as a model boundary condition, this process insured that the reach-averaged water-surface slope simulated by MD_SWMS matched the measurements. MD_SWMS can also compute the drag coefficient based on grain size data. Some grain size data available from Brabets (1997) were used to compute the drag coefficient to compare to the final value used in the simulation. 
MD_SWMS incorporates a lateral eddy viscosity (LEV) to represent lateral momentum exchange due to turbulence or other variability that is not generated at the channel bed (Nelson and others, 2003). The model's LEV parameter was computed for each model calibration condition using the following equation:

where

$$
\mathrm{LEV}=0.01 * \mathrm{u}_{\mathrm{ave}} * \mathrm{y}_{\text {ave }},
$$

LEV is lateral eddy-viscosity coefficient, in $\mathrm{m}^{2} / \mathrm{s}$; $u_{\text {ave }}$ is average velocity, in $\mathrm{m} / \mathrm{s}$; and $\mathrm{Y}_{\text {ave }}$ is average depth, in $\mathrm{m}$.

The computed LEV value was applied uniformly throughout the modeled reach for each calibration streamflow. Similar to the drag coefficient, the LEV was adjusted within reasonable limits (based on field data) during the calibration process to reproduce as closely as possible the measured water-surface elevation.

As an additional check of the accuracy of the calibration, model convergence is evaluated by MD_SWMS by comparing the predicted model discharge to the observed specified discharge for a selected cross section. For this study, MD_SWMS was run for 500 iterations. If the percent deviation from the normalized discharge was within \pm 3 percent, the convergence was considered acceptable. If the convergence was greater than \pm 3 percent, the values for the drag coefficient and LEV were checked to make sure they were within reasonable limits. Next, the relaxation parameters E (water-surface elevation), U (velocity), and A (global slope) were adjusted. For this study, model calibration was considered acceptable if the predicted versus observed watersurface elevations were within $\pm 1.5 \mathrm{ft}$ and convergence was within \pm 3 percent. A plus or minus $1.5 \mathrm{ft}$ in stage represents a discharge within 10 percent. Given the magnitude of flows for the Copper River, we felt this was an acceptable range.

Boundary conditions used during model calibration include (1) streamflow and water-surface elevations at the upstream model boundary, and (2) water-surface elevations at the downstream model boundary. For the Bridge 339 area, flows and corresponding water-surface elevations were measured at the bridge. Using the LIDAR data, the upstream and downstream water-surface elevations were interpreted for inputs to MD_SWMS. Streamflows for the Mile 43.5 area were based on discharge from the gaging station at the Million Dollar Bridge and water-surface elevations measured at several points between the upstream and the downstream boundaries of the modeled area (fig. 21).
For the Bridge 339 area, MD_SWMS was calibrated to the observed water-surface elevation at a discharge of $32,500 \mathrm{ft}^{3} / \mathrm{s}$. This was the highest discharge measured during the study, and field observations confirmed that scour takes place along the approach to the bridge and at the bridge piers. For the Mile 43.5 area, the Copper River affects the highway at discharges of approximately $100,000 \mathrm{ft}^{3} / \mathrm{s}$ or greater. The model was calibrated to water-surface elevations measured at various discharges ranging from 75,500 to $271,000 \mathrm{ft}^{3} / \mathrm{s}$.

\section{Sediment Mobility}

Because the ability of water to move sediment in a stream most often is related to the shear stress at the streambed, after the model was calibrated to observed water-surface elevations, subsequent model runs were made to compute the critical bed shear stress. FaSTMECH calculates bed shear stress as follows:

where

$$
\mathrm{Tb}=\operatorname{pCd}\left(\mathrm{u}^{2}+\mathrm{v}^{2}\right)
$$

Tb is boundary shear stress, in Newtons per square meter;

pis fluid density, in $\mathrm{kg} / \mathrm{m}^{3}$;

$\mathrm{Cd}$ is the non-dimensional drag coefficient;

$\mathrm{u}$ is vertically averaged stream wise velocity, in $\mathrm{m} / \mathrm{s}$; and

Vis vertically averaged cross-stream velocity, in $\mathrm{m} / \mathrm{s}$.

Julien (1998) summarized the critical shear stress values for a range of sediment sizes (table 4). Sediment mobility for a given grain size occurs when the boundary shear stress exceeds the critical shear stress. The calculated shear stress values were compared for several particle sizes representative of the two modeled reaches of the Copper River to assess sediment mobility. It should be noted that the comparison of shear stress output from MD_SWMS to the shear stress values from Julien indicates only whether or not a given grain size is likely to become mobile. MD_SWMS does not calculate potential for erosion or deposition. For the Bridge 339 area, a bed-material size of $8 \mathrm{~mm}$, based on bed material samples collected by Brabets (1997), was used as input to MD_SWMS to compute the critical shear stress of the river bed. For the Mile 43.5 area, a bed-material size of $10 \mathrm{~mm}$ was used as input to MD_SWMS. 
Table 4. Sediment grade scale and critical shear stress for determining approximate condition for sediment mobility at 20 degrees Celsius.

[Source of data, Julien (1998) Abbreviations mm, millimeter; $\mathrm{N} / \mathrm{m}^{2}$, newtons per square meter; > greater than]

\begin{tabular}{|c|c|c|}
\hline Class name & $\begin{array}{l}\text { Diameter } \\
(\mathrm{mm})\end{array}$ & $\begin{array}{c}\text { Critical shear stress } \\
\left(\mathrm{N} / \mathrm{m}^{2}\right)\end{array}$ \\
\hline \multicolumn{3}{|l|}{ Boulder } \\
\hline Large & $>1.024$ & 895 \\
\hline Medium & $>512$ & 447 \\
\hline Small & $>256$ & 223 \\
\hline \multicolumn{3}{|l|}{ Cobble } \\
\hline Large & $>128$ & 111 \\
\hline Small & $>64$ & 53 \\
\hline \multicolumn{3}{|l|}{ Grave } \\
\hline Very course & $>32$ & 26 \\
\hline Coarse & $>16$ & 12 \\
\hline Medium & $>8$ & 5.7 \\
\hline Fine & $>4$ & 2.71 \\
\hline Very Fine & $>2$ & 1.26 \\
\hline \multicolumn{3}{|l|}{ Sand } \\
\hline Very coarse & $>1$ & 0.470 \\
\hline Coarse & $>.5$ & .270 \\
\hline Medium & $>.25$ & .194 \\
\hline Fine & $>.125$ & .145 \\
\hline Very fine & $>.0625$ & .110 \\
\hline \multicolumn{3}{|l|}{ Silt } \\
\hline Coarse & $>.031$ & .083 \\
\hline Medium & $>.016$ & .065 \\
\hline
\end{tabular}

\section{Current Conditions and Possible Betterments at Bridge 339}

Erosion and undercutting of the west approach to Bridge 339 is likely to continue based on discharge measurements (and the corresponding velocities) made from 2005 to 2007 and field observations. The approach consists of fine-grained material (fig. 22A), and during this study ADOT\&PF needed to replace the riprap repeatedly. Approximately 10,000 cubic yards of riprap have been placed along the approach since 2004, and during the October 2006 flood, all the material was washed away (fig. 22B).
Additionally, there was a tendency for flow to enter another channel toward Bridge 336 (fig. 23). This channel flows in a sinusoidal pattern, first flowing southwest and impacting the road, then flowing northwest, and again flowing southwest before passing through Bridge 336. Where the channel impacts the road, there is no riprap armor, the material of the roadbed is similar to that of the approach at Bridge 339, and the road grade is lower than Bridge 336. Thus, in addition to continuing problems at Bridge 339, problems also could arise along the highway between Bridge 336 and Bridge 339, as well as at Bridge 336. The design discharge for Bridge 336 is 8,500 $\mathrm{ft}^{3} / \mathrm{s}$ and measured discharges to date have been less than this value.

Some solutions or betterments that have been considered for Bridge 339 are (1) constructing a $250 \mathrm{ft}$ guide bank on the west upstream side of Bridge 339 to direct the water perpendicular to the bridge opening, (2) re-channelization of approximately $1,000 \mathrm{ft}$ of channel directly upstream of Bridge 339 to align the flow perpendicular to the center of the bridge, and (3) extending the bridge $240 \mathrm{ft}$ to the west (fig. 24). The developed MD_SWMS model was used to simulate flow conditions for these three betterment scenarios at a discharge of $32,500 \mathrm{ft}^{3} / \mathrm{s}$

\section{Results of Simulations at Bridge 339}

The final calibration run of the model for the Bridge 339 area for $32,500 \mathrm{ft}^{3} / \mathrm{s}$ calculated a water-surface elevation of $51.94 \mathrm{ft}$ compared with the measured water surface of $51.08 \mathrm{ft}$ at the bridge. Calculated water velocities were as high as $8.6 \mathrm{ft} / \mathrm{s}$, and the highest velocities were along the right bank and the approach to Bridge 339 (fig. 25A). The final values for the LEV and drag coefficient were $0.54 \mathrm{ft}^{2} / \mathrm{s}$ and 0.007 , respectively. During the calibration procedure, the drag coefficient was the most sensitive input parameter. This highlights the importance of accurately calibrating the model to the channel's roughness, mainly to accurately simulate shear stress. Shear-stress values ranged from 0.21 to $1.04 \mathrm{lb} / \mathrm{ft}^{2}$ (fig. 25B). Based on previous work by Julien (1998), for a bed material diameter of 0.31 in., the critical shear stress for mobility would be $0.12 \mathrm{lb} / \mathrm{ft}^{2}$. Thus, the modeled reach would be considered as a mobile bed. Field observations indicate that the channel is constantly changing, which verifies, to a certain extent, the output from MD_SWMS. Based on the results from MD_SWMS, it was determined that the model represented the current conditions adequately and that it could be used to simulate the various betterments. 


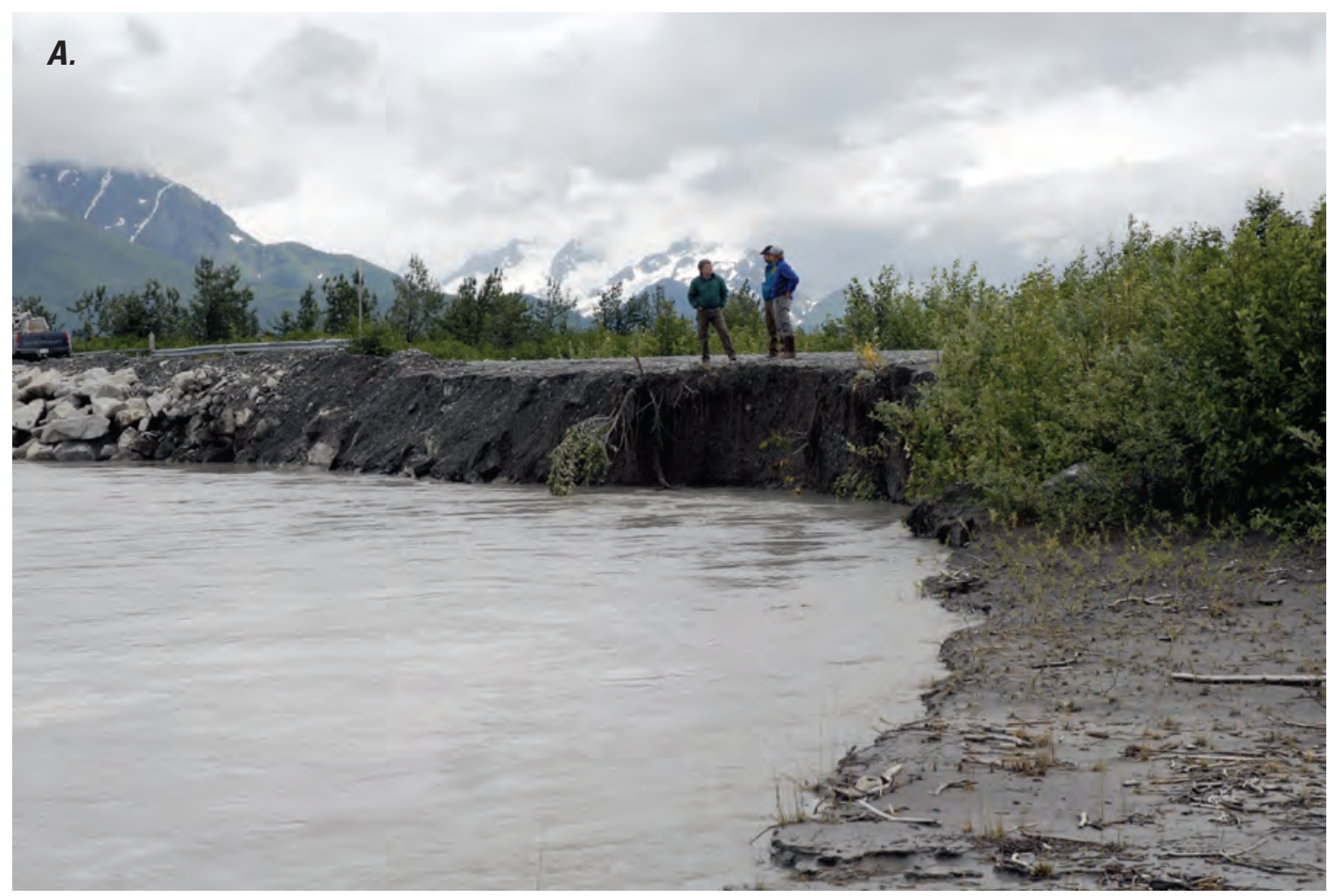

Photograph taken by Timothy Brabets, U.S. Geological Survey, July 31, 2006

B.

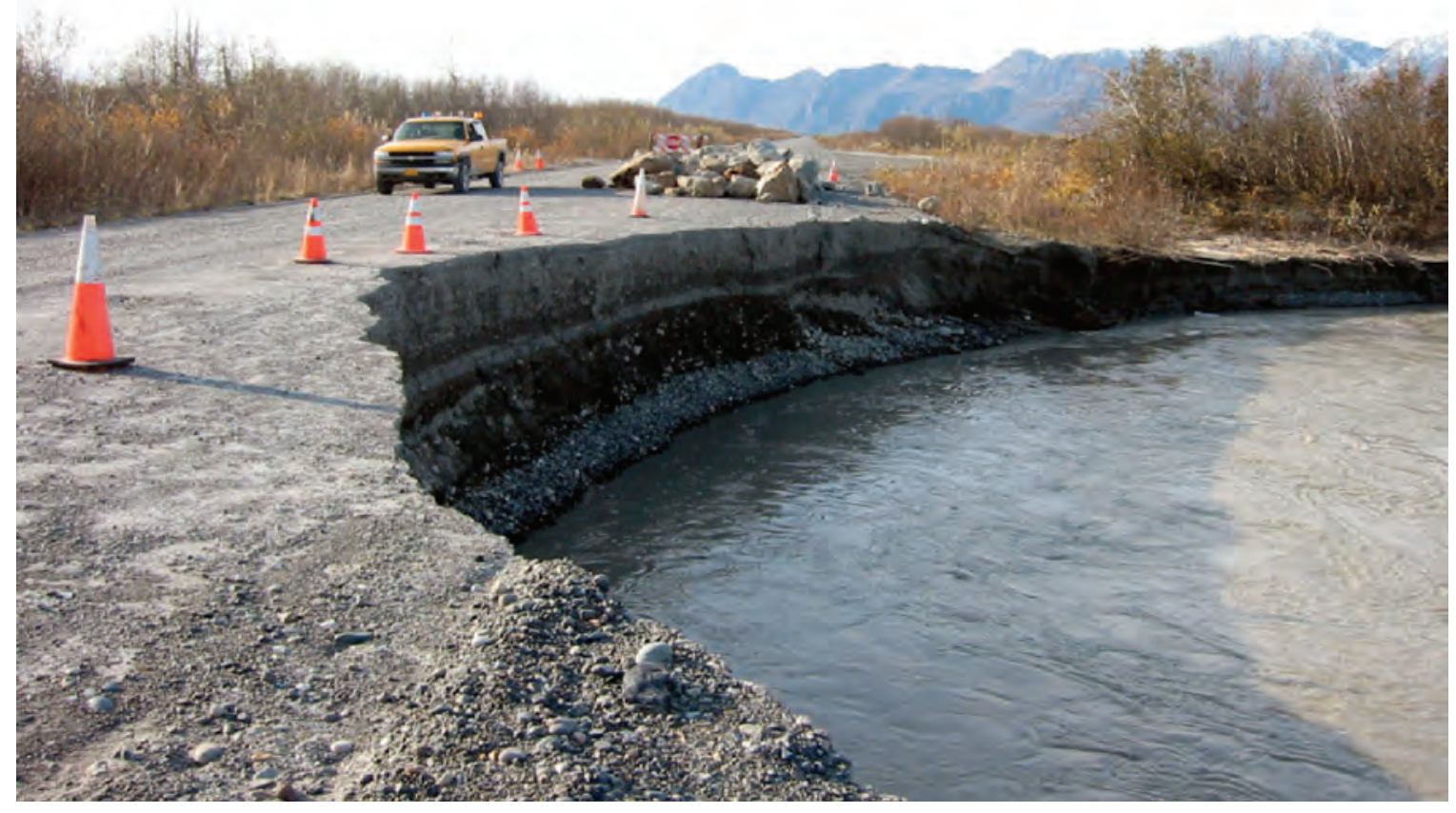

Photograph taken by Alaska Department of Transportation, October 2006

Figure 22. Copper River Highway road bank material near Bridge $339(A)$ looking east and $(B)$ looking west, lower Copper River, Alaska. 


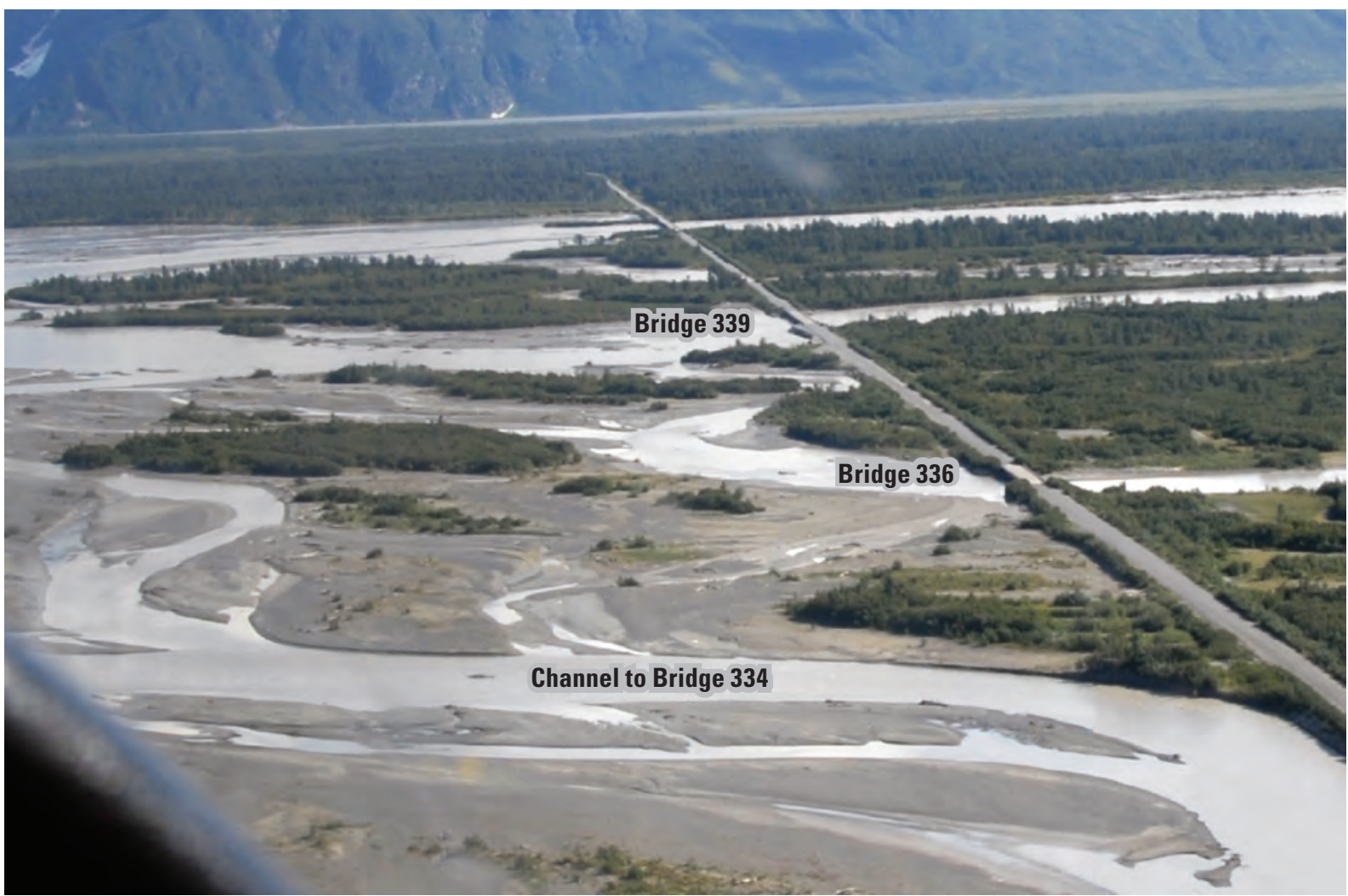

Photograph taken by Timothy Brabets, U.S. Geological Survey, August 30, 2007

Figure 23. Copper River Highway river channels near Bridge 339, lower Copper River, Alaska.

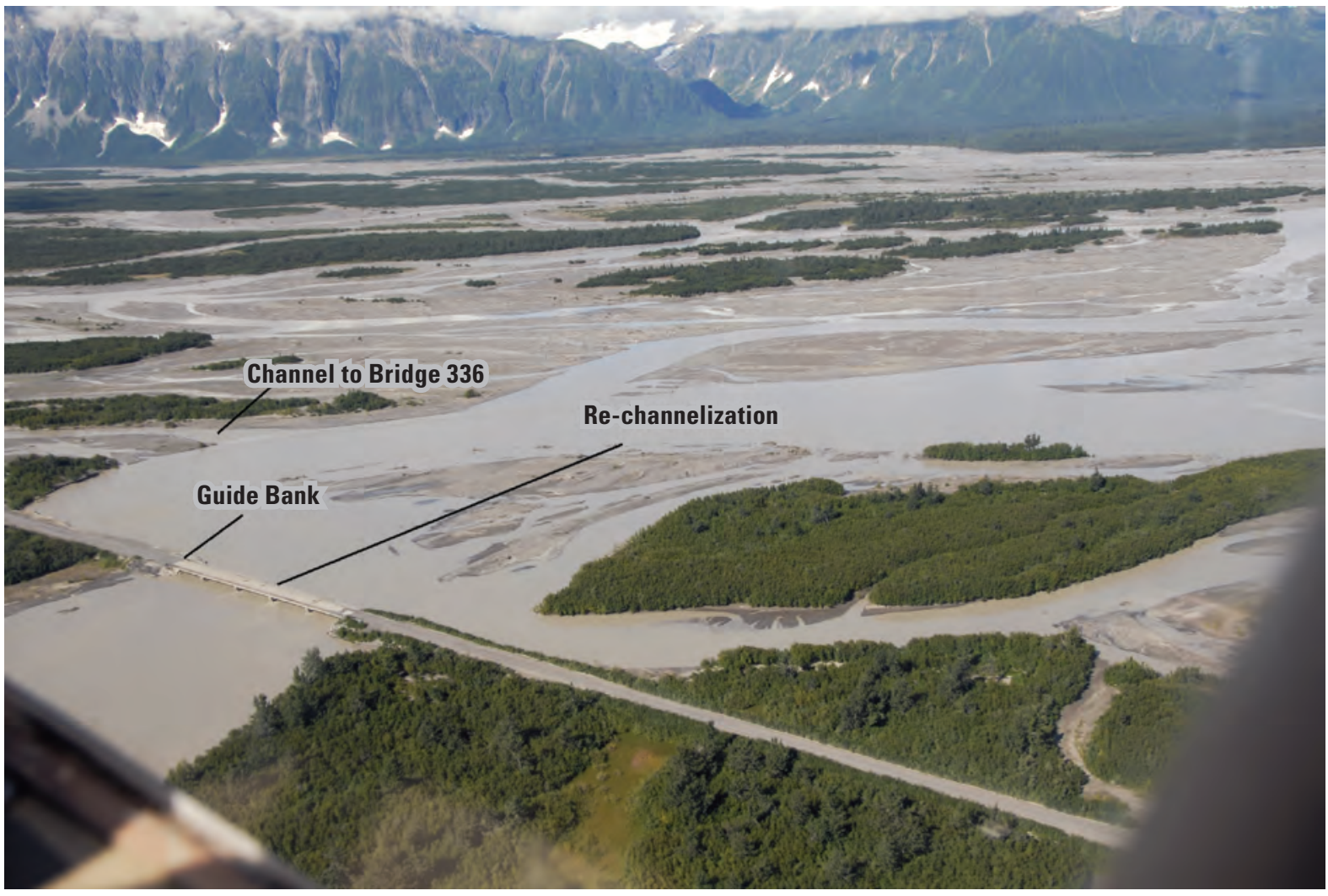

Photograph taken by Timothy Brabets, U.S. Geological Survey, August 30, 2007

Figure 24. Copper River Highway at Bridge 339 showing possible betterments lower Copper River, Alaska. 


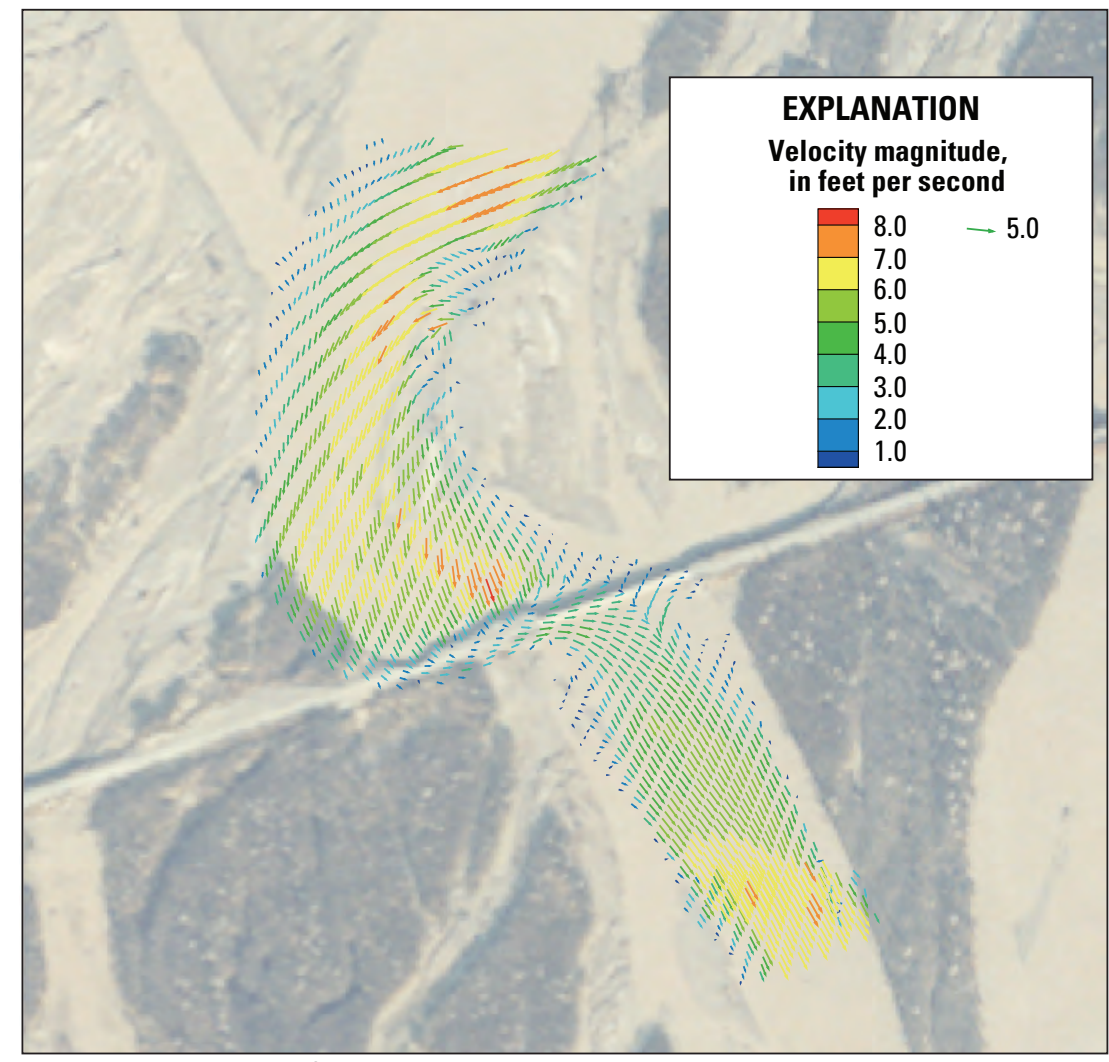

Photograph taken by Aero-Metric, October 15, 2006.

\section{A. Current (2008) velocity}

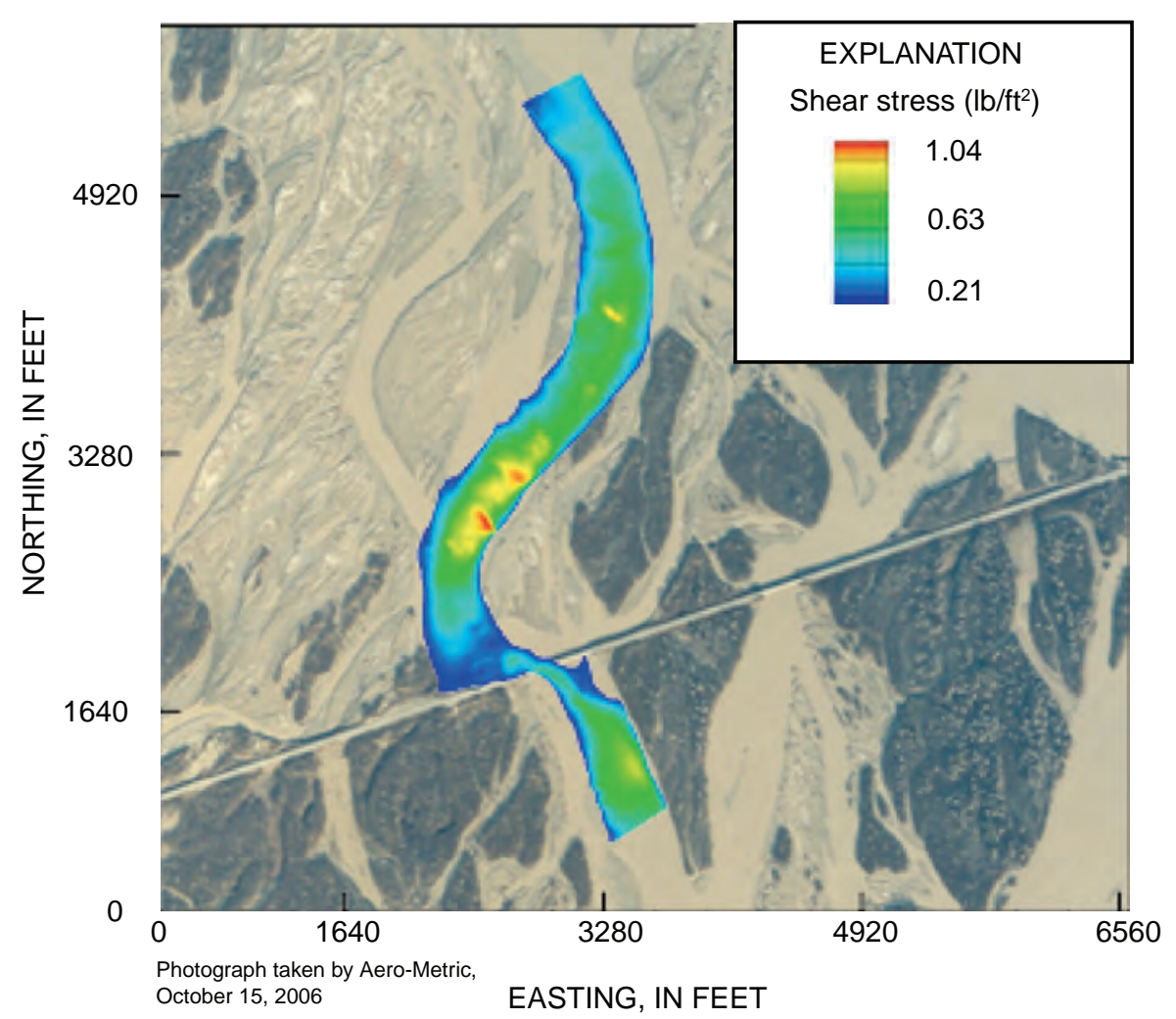

B. Current (2008) shear stress

Figure 25. Results from MD_SWMS simulation of the main channel near Bridge 339 at a discharge of $32,500 \mathrm{ft}^{3} / \mathrm{s}$ : $(A)$ velocity, no changes, $(B)$ shear stress, no changes, $(C)$, water-surface elevation with $250 \mathrm{ft}$ guide bank, $(D)$ velocity with re-channelization, and $(E)$ velocity with $240 \mathrm{ft}$ bridge extension. 


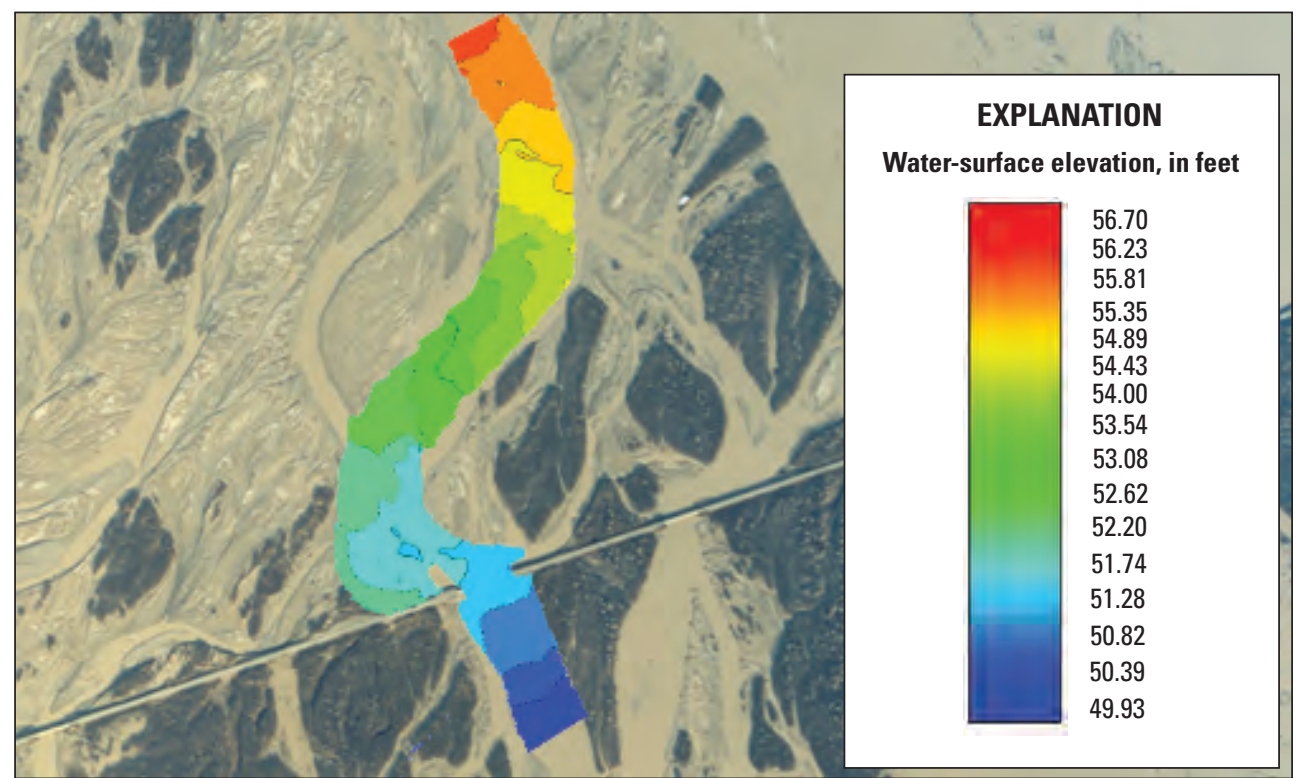

Photograph taken by Aero-Metric, October 15, 2006.

C. With 250 foot guide bank

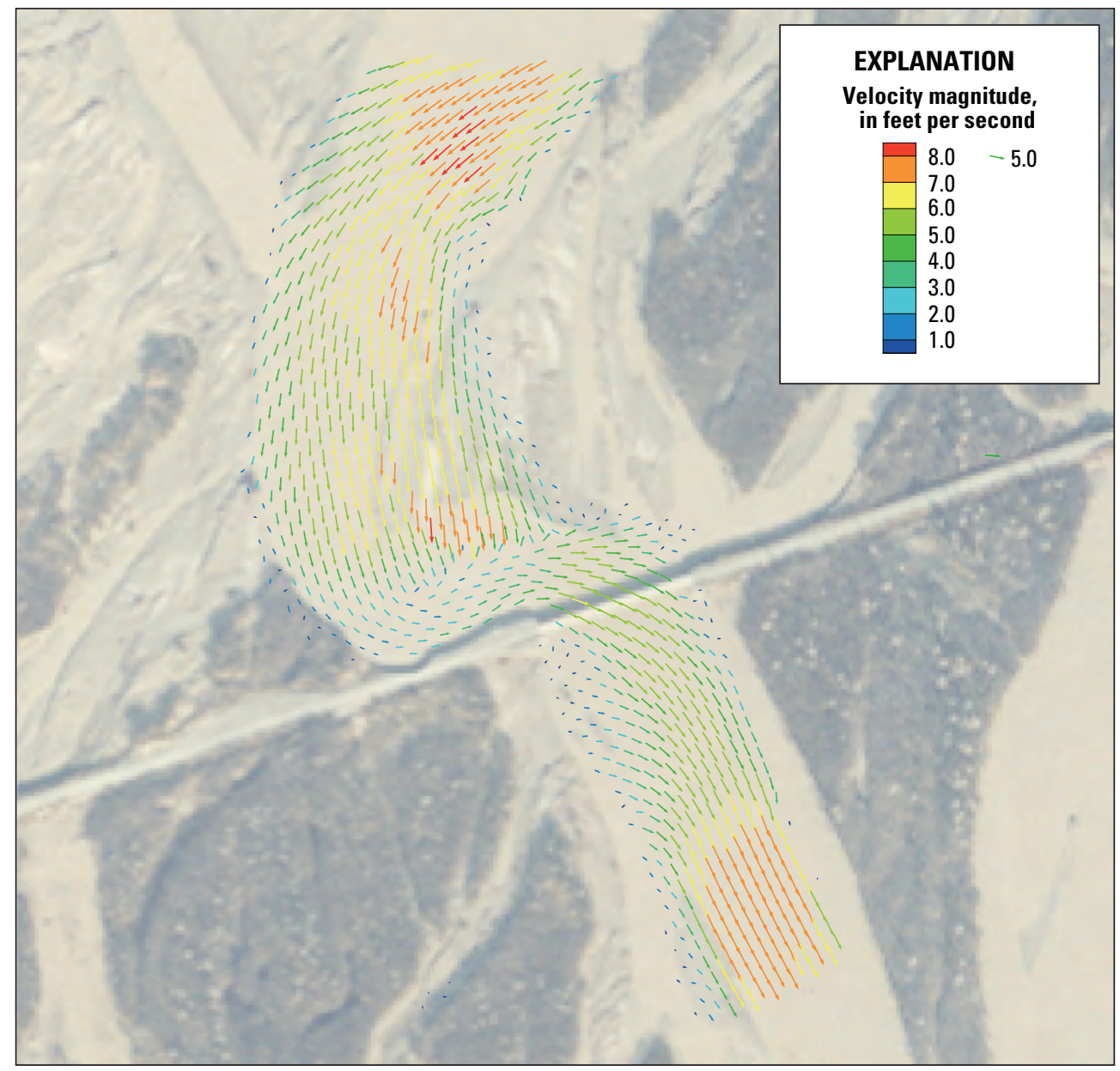

Photograph taken by Aero-Metric, October 15, 2006.

D. Proposed re-channelization

Figure 25.-Continued 


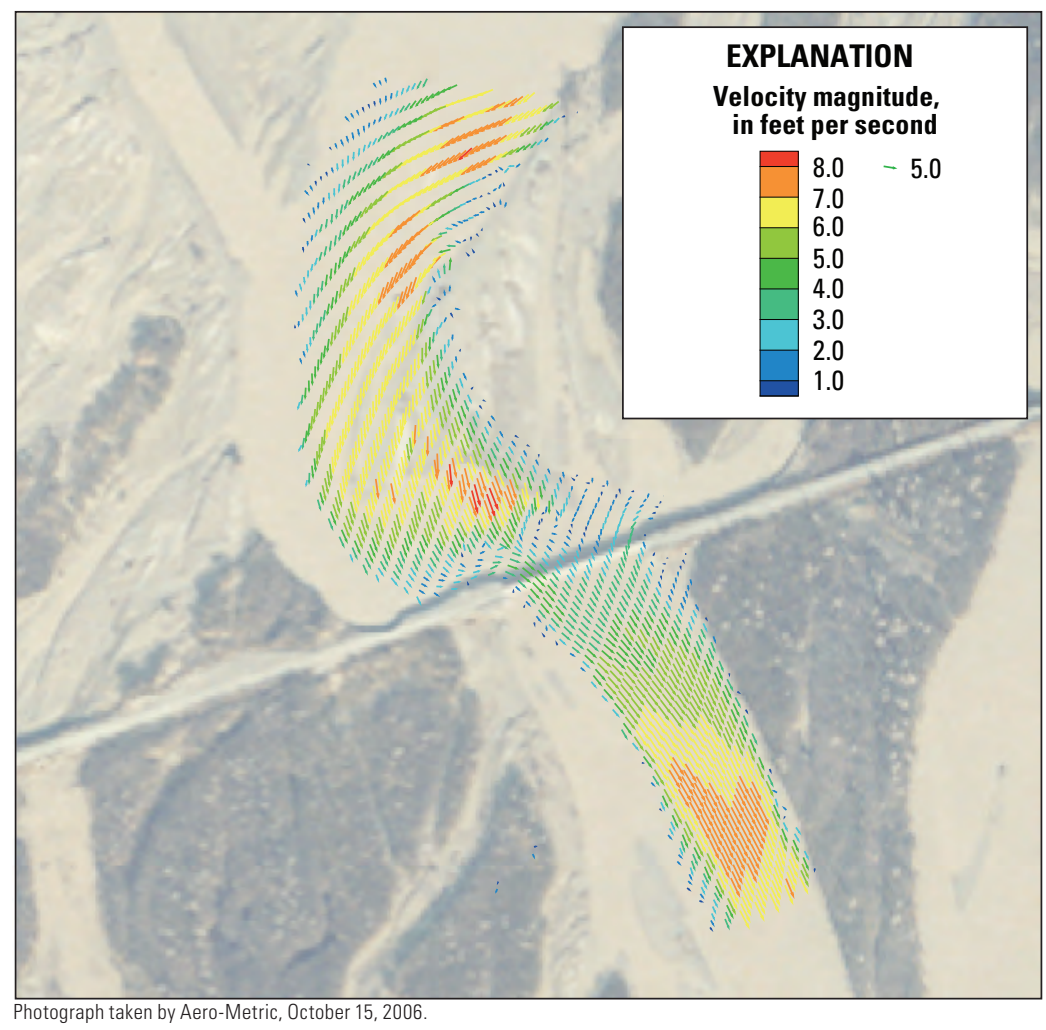

E. Extension of Bridge 339

Figure 25.-Continued

As proposed, a 250-ft long guide bank would be constructed perpendicular to the roadway and then angle slightly to the west to alter the direction of flow to be perpendicular to the opening of Bridge 339. However, the output from MD_SWMS, when the guide bank dimensions were added, did not indicate such a change in flow alignment would take place. Water velocities, velocity vectors, and bed shear stresses simulated by the model were nearly identical to those under current conditions, which would indicate that most of the flow still would be directed to the approach and not to the bridge (fig. 25A). The likely cause of this simulation result is that a $250-\mathrm{ft}$ guide bank is too short to alter the flow direction and would need to be lengthened. A possible negative impact of the guide bank, based on the output from MD_SWMS, is that it would increase the water-surface elevation along the right bank (fig. 25C). Such an increase in water-surface elevation would increase flow toward Bridge 336. However, no attempt was made to determine the amount of flow toward this bridge.

A proposed re-channelization near the Bridge 339 area would consist of the following: The channel would be dredged approximately $1,000 \mathrm{ft}$, beginning at or near the upstream center of Bridge 339 and perpendicular to the bridge. The "new" channel width would be $150 \mathrm{ft}$ and the elevation of the channel bed would be approximately $36 \mathrm{ft}$. Currently (2008), the elevation of the channel bottom ranges from 41 to $52 \mathrm{ft}$. Using these parameters, the DEM was modified and MD_SWMS runs were made. For this betterment, MD_SWMS did show that the highest velocities would be through the dredged channel, an indication that most of the $32,500 \mathrm{ft}^{3} / \mathrm{s}$ would be through this channel and perpendicular to the bridge (fig. 25D). It is important to note, however, that based on the calculated shear stresses, the entire channel is mobile. Thus, it is possible that the dredged channel could fill in during high flows and the water would re-occupy the original channel.

The third betterment that was analyzed was an extension of Bridge 339. Currently, any extension of Bridge 339 probably would be to the west. However, a thorough analysis of channel migration should be done before a final decision is made. Because the main channel is currently on the right bank and a bridge extension would consist of $80 \mathrm{ft}$ sections, a $240 \mathrm{ft}$ extension of Bridge 339 to the west was used for modeling purposes. 
If Bridge 339 were extended $240 \mathrm{ft}$ to the west, modeling indicated that the water velocity would be lower than velocities under current conditions, and that flow would be uniform across the channel (fig. 25E). Thus, the flow would be more nearly centered through the bridge. On the basis of calculated shear stress values, the channel would still be considered mobile, but the potential for scour would be considered low due to the lower shear stress values.

\section{Current Conditions and Possible Betterments at Mile 43.5}

Currently (2009), the Copper River is within $100 \mathrm{ft}$ of the Copper River Highway near Mile 43.5 (fig. 15). At flows greater than approximately $100,000 \mathrm{ft}^{3} / \mathrm{s}$, the area adjacent to the highway from about Mile 40 to Mile 43.5 becomes inundated (fig. 16). In September 2007, the highway was almost overtopped at a river discharge of $271,000 \mathrm{ft}^{3} / \mathrm{s}$; therefore, higher flows are expected to flood the highway. A potential solution to the flooding along Mile 40-43.5 would be to place a dike at about Mile 44 to divert the channel away from the highway toward the old channel that flows to the west (fig. 26).

MD_SWMS was calibrated for the Mile 43.5 area for a range of flows. Nine different flows were simulated, ranging from $75,000 \mathrm{ft}^{3} / \mathrm{s}$ to $271,000 \mathrm{ft}^{3} / \mathrm{s}$ (table 5). Water-surface elevations were available at five locations (fig. 21) for most discharges. The location of these data was important because the water surface was higher at the left bank than at the right bank, and a two-dimensional analysis was necessary. After model calibration was complete, a hypothetical dike was placed at about Mile 44 and runs of MD_SWMS were made to examine the subsequent change in hydraulic conditions.

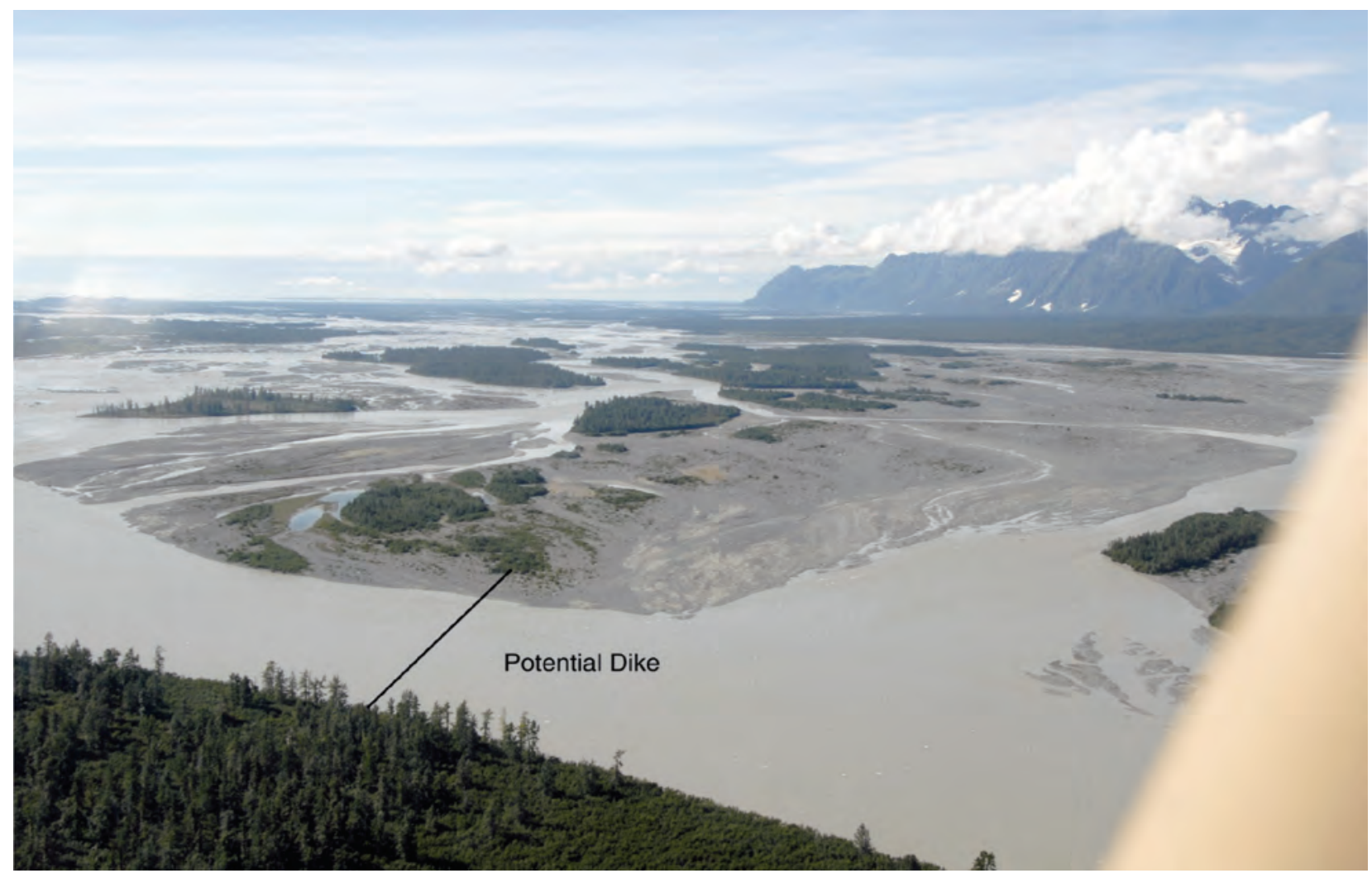

Photograph taken by Timothy Brabets, U.S. Geological Survey, August 30, 2007

Figure 26. Area near Mile 45 looking downstream showing location of possible dike to change direction of flow toward the west, lower Copper River, Alaska. 


\section{Results of Simulations at Mile 43.5 Area}

As noted previously, because of safety concerns bathymetric data for the upper part of the computational grid could not be collected and had to be estimated. When the first runs of MD_SWMS were made, the simulated flow was equally distributed along the left and right banks, which is not the current condition. Based on discharge measurements, for example, at a discharge of $200,000 \mathrm{ft}^{3} / \mathrm{s}$, about $150,000 \mathrm{ft}^{3} / \mathrm{s}$ flowed along the left bank and about $50,000 \mathrm{ft}^{3} / \mathrm{s}$ flowed along the right bank. Similarly, at discharges less than $75,000 \mathrm{ft}^{3} / \mathrm{s}$, most of the flow was along the left bank. Thus, the bathymetry in the upper portion of the computational grid was adjusted to allow more flow along the left bank. The need for such adjustment points out the sensitivity of the model to initial input parameters and the importance of constructing an accurate DEM when using two-dimensional models. Because of the estimated bathymetry data gap, the model simulation results for the mile 43.5 area provided more of a conceptual rather than a detailed picture of current conditions.

For the nine calibration discharges, the drag coefficient ranged from 0.0035 to 0.0048 , and LEV ranged from 0.538 to 0.861 (table 5). LEV showed a generally upward trend with increasing discharge. Comparisons between observed and computed water-surface elevations were good (fig. 27). For all discharges, the model predicted a lower water-surface elevation than that observed at the upstream boundary. This difference may due to the fact that the observed watersurface elevation is based on the slope between the Million Dollar Bridge and the upstream boundary of the model; that slope was derived from the LIDAR data. The model usually predicted a higher water-surface elevation at the left edge of the downstream boundary. This might be caused by errors in the bathymetry in this part of the computational grid.

After the model was calibrated for the nine discharges, a hypothetical dike was placed upstream of Mile 43.5, using tools in MD_SWMS that allow for adjustments to the topography. The dike was approximately $1,000 \mathrm{ft}$ long and $100 \mathrm{ft}$ wide, with an upper elevation of $125 \mathrm{ft}$ (the same as the left-bank elevation). At the location of the dike, the model bathymetry was changed from 87 to $125 \mathrm{ft}$ (top of bank). Comparisons between the MD_SWMS output for current conditions and conditions with the dike in place (fig. 28) showed that the dike would redirect flow to the west and would cause an increase in the water-surface elevation on the right side of the channel.

Table 5. Discharges and boundary conditions used by Multi-Dimensional Surface Water Modeling System for Mile 43.5 area of the lower Copper River, Alaska.

[Abbreviations: $\mathrm{ft}^{3} / \mathrm{s}$, cubic foot per second; $\mathrm{ft}$, foot; $\mathrm{ft}^{2} / \mathrm{s}$, foot squared per second]

\begin{tabular}{|c|c|c|c|c|c|c|}
\hline \multirow[b]{2}{*}{ Date } & \multirow{2}{*}{$\begin{array}{c}\text { Discharge } \\
\left(\mathrm{ft}^{3} / \mathrm{s}\right)\end{array}$} & \multicolumn{3}{|c|}{ Boundary elevation } & \multirow[b]{2}{*}{ Drag coefficient } & \multirow{2}{*}{$\begin{array}{l}\text { Lateral eddy } \\
\text { viscosity } \\
\left(\mathrm{ft}^{2} / \mathrm{s}\right)\end{array}$} \\
\hline & & $\begin{array}{l}\text { Upstream } \\
\text { (ft) }\end{array}$ & $\begin{array}{l}\text { Right downstream } \\
\text { (ft) }\end{array}$ & $\begin{array}{l}\text { Left downstream } \\
\text { (ft) }\end{array}$ & & \\
\hline 9-27-2007 & 75,000 & 109.68 & 66.30 & 78.12 & 0.0040 & 0.538 \\
\hline 9-21-2005 & 97,700 & 112.79 & 67.77 & 79.66 & .0035 & .538 \\
\hline 6-01-2006 & 111,000 & 113.29 & 67.49 & 79.49 & .0040 & .538 \\
\hline 8-17-2007 & 176,000 & 117.81 & 72.34 & 80.48 & .0036 & .538 \\
\hline 8-10-2005 & 177,000 & 118.27 & 73.95 & 81.00 & .0039 & .538 \\
\hline 7-19-2006 & 185,000 & 119.22 & (1) & (1) & .0035 & .538 \\
\hline 8-01-2007 & 197,000 & 118.86 & 72.64 & 81.72 & .0035 & .592 \\
\hline 7-14-2005 & 232,000 & 122.77 & 74.80 & 82.71 & .0035 & .592 \\
\hline 9-11-2007 & 271,000 & 121.62 & 73.98 & 81.89 & .0048 & .861 \\
\hline
\end{tabular}

\footnotetext{
${ }^{1}$ Water-surface elevations not known at downstream boundary; known at middle of grid.
} 



\section{EXPLANATION}

$\triangle$ Measured

$\triangle$ Computed

Figure 27. Measured compared with computed water-surface elevations for various discharges, computed by Multi-Dimensional Surface Water Modeling System, lower Copper River, Alaska. 


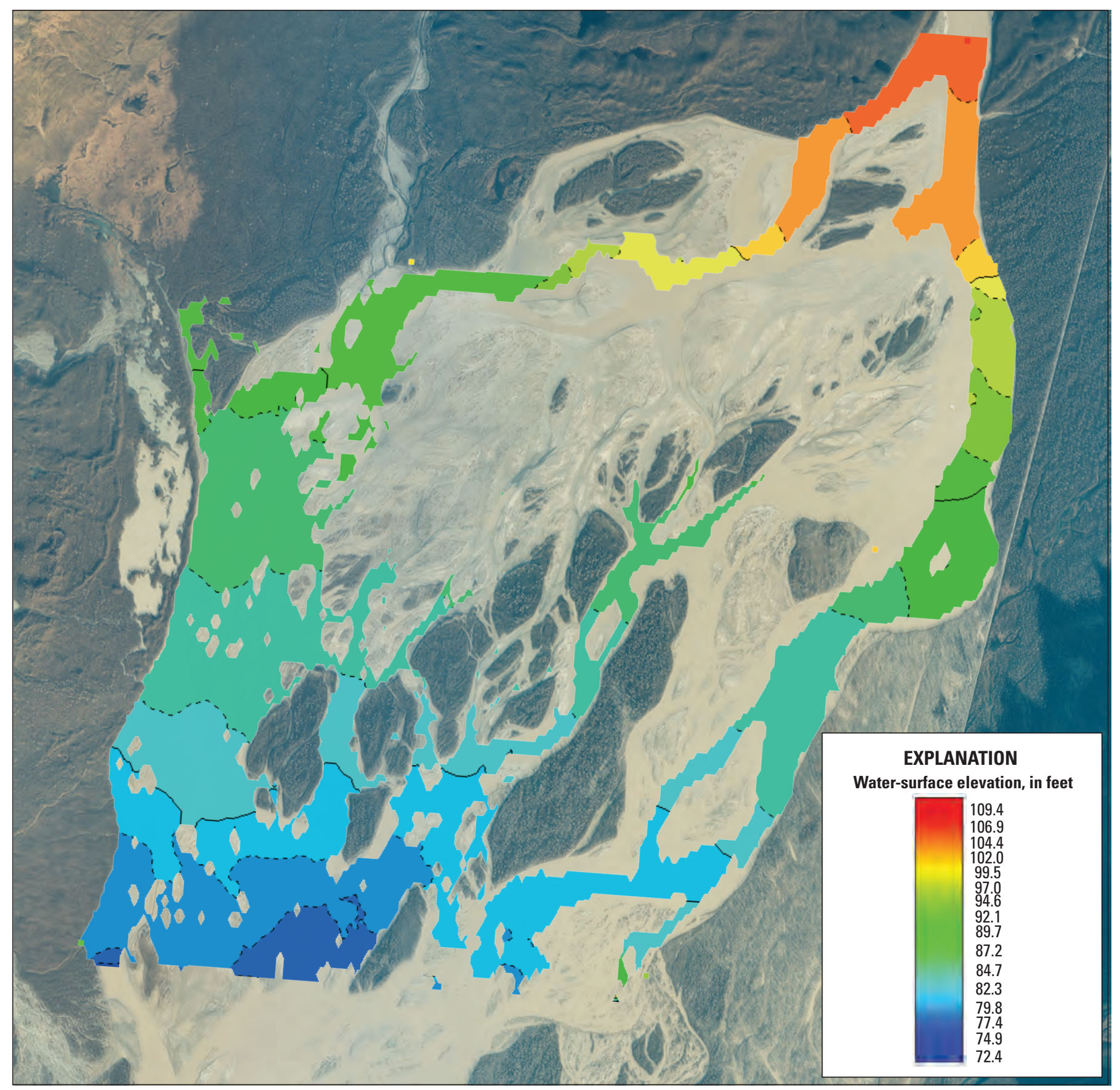

Photograph taken by Aero-Metric, Inc. October 15, 2006.

\section{A. Without dike}

Figure 28. Water surface-elevations computed by Multi-Dimensional Surface Water Modeling System for a flow of 177,000 $\mathrm{ft}^{3} / \mathrm{s}(A)$ without dike and $(B)$ with dike, near Mile 43.5, lower Copper River, Alaska. 




Photograph taken by Aero-Metric, Inc. October 15, 2006.

\section{$B$. With dike}

Figure 28.-Continued 


\section{Model Limitations and Sensitivity}

An evaluation of the applicability of MD_SWMS to the two areas of concern along the Copper River Highway requires consideration of the model's limitations. These limitations fall into two groups: (1) the capabilities of MD SWMS and (2) the quality and quantity of the field data. At present, MD_SWMS can compute the bed shear stress, and if bed-material data are available, the user can determine if the streambed is mobile based on Julien's work. However, MD_SWMS does not compute scour or bed movement, which field observations indicate is occurring at both the Bridge 339 and Mile 43.5 areas. The field data required to develop the models for the two areas consist primarily of topography, bathymetry, discharge, and corresponding water-surface elevations. For the Bridge 339 area, LIDAR and the associated bathymetry provided a good data set to construct the DEM. Although discharge values and water surface elevations are considered accurate-within 5 percent-some error is still introduced. For the Mile 43.5 area, where the modeled area is much larger than the Bridge 339 model area, most of the DEM consists of the LIDAR data set. Discharge data from the gaging station at the Million Dollar Bridge are consideredwithin 5 percent, as are the water-surface elevations obtained at various flows. However, bathymetry was not measured, but had to be estimated, in a critical area, the upstream boundary of the computational grid, which limits the model's capabilities.

Sensitivity analysis of the model for the Bridge 339 area consisted of decreasing and increasing the calibrated drag coefficient by 25 percent for the current conditions and the three betterments (table 6). The analysis compared the median water-surface elevation, velocity, and computed shear stress. Varying calibrated drag coefficients by \pm 25 percent changed the median water-surface elevations and velocities only slightly, indicating these parameters are not sensitive to the choice of drag coefficient. Model-simulated shear stress changed proportionally with the drag coefficient, indicating the importance of first calibrating the model to the roughness, because MD_SWMS uses the roughness to compute the shear stress.
Table 6. Results of sensitivity analysis of Muti-Dimensional Surface Water Modeling System when drag coefficient is adjusted plus and minus 25 percent for Bridge 339 area, lower Copper River, Alaska.

[Values for drag coefficient are dimensionless and represent value used in the model (0.007), less 25 percent $(0.0052)$ and plus 25 percent (0.0087); values for water surface elevation, velocity, and shear stress are median values.

Abbreviations $\mathrm{ft}$, foot; ft/s, foot per second; $\mathrm{lb} / \mathrm{ft}^{2}$, pound per square foot]

\begin{tabular}{cccc}
\hline Drag coefficient & $\begin{array}{c}\text { Water } \\
\text { surface } \\
\text { elevation } \\
\text { (ft) }\end{array}$ & $\begin{array}{c}\text { Velocity } \\
\text { (ft/s) }\end{array}$ & $\begin{array}{c}\text { Shear stress } \\
\left(\mathbf{l b} / \mathbf{f t}^{2}\right)\end{array}$ \\
\hline Current conditions & 52.4 & 5.5 & 708 \\
0.0052 & 52.4 & 5.2 & 847 \\
.0070 & 52.5 & 5.0 & 953 \\
.0087 & & & \\
Guide bank & 52.8 & 5.8 & 785 \\
0.0052 & 52.8 & 5.5 & 948 \\
.0070 & 53.1 & 5.2 & 1,077 \\
.0087 & & & \\
Channelization & 52.5 & 5.6 & 737 \\
0.0052 & 52.5 & 5.4 & 900 \\
.0070 & 52.5 & 5.2 & 1,039 \\
.0087 & & & 785 \\
Bridgeextension & 52.8 & 5.8 & 948 \\
0.0052 & 52.8 & 5.5 & 1,077 \\
.0070 & 52.8 & 5.2 & \\
.0087 & & & \\
\hline
\end{tabular}

\section{Summary and Conclusions}

In a previous study of the lower Copper River, various years of aerial photography were examined to document the changes and migration of the main channels of the lower Copper River and the corresponding effects on the Copper River Highway and its associated bridges. That study indicated that most likely, a flood in 1981 with a discharge large enough to have a less than 1 percent chance of occurring in a given year caused a major channel shift. Channels remained relatively stable following the 1981 flood based on analyses of aerial photography taken in 1991 and 1996. Due to high flows in 2001, one channel migrated toward Mile 43.5 of the Copper River Highway and another channel migrated toward Bridge 339. The channel change at Mile 43.5 now inundates the area adjacent to the highway at moderate flows and has damaged the highway. Near Bridge 339, channel migration and an increase in the percentage of flow in this channel has resulted in damage to the approach to the bridge. 
Most of the annual flow of the Copper River occurs from June to September. Historically, as late as 1970, most of the flow was through Bridges 331, 1187, and 332, located at Flag Point (Mile 27 of the highway). In the mid-1990s, about 50 percent of the total flow of the river passed through these bridges and 40 percent of the flow passed through Bridge 342 . Discharge measurements made during this study at bridges along the Copper River Highway indicate that currently (2008), 60 to 100 percent of the flow of the Copper River passes through Bridge 342 depending on the discharge at the Million Dollar Bridge. These changes in flow distribution verify that channels of the lower Copper River are migrating.

The U.S. Geological Survey's Multi-Dimensional Surface Water Modeling System was used in the current study to simulate water-surface elevation, velocity, and then to compute the shear stress from the predicted velocities near Mile 43.5 and near Bridge 339 in order to evaluate the potential effects of proposed betterments to protect the Copper River Highway. The model's ability to simulate these betterments was somewhat constrained by the accuracy and level of channel geometry detail and thus the output from the model should not be used for exact or detailed design of a potential betterment. However, the developed model provided sound conceptual information that could be used to evaluate the effectiveness of a proposed betterment or determine potential problems that need to be addressed for a particular betterment. The betterments included a $250 \mathrm{ft}$ guide bank, re-channelization and a $240 \mathrm{ft}$ bridge extension at Bridge 339, and a diversion dike near Mile 43.5. At Bridge 339, the outputs from MD_SWMS indicated that the guide bank would be too small to affect any changes in the hydraulic conditions. Re-channelization upstream of the bridge would align the flow perpendicular to the bridge but given the mobile bed, the channel could fill in during high flows. If the bridge were lengthen, flow would be more uniform across the channel and the potential for scour would decrease. At Mile 43.5, placement of a dike would divert flow to the west and decrease flow toward the Copper River Highway.

\section{Acknowledgments}

The authors gratefully appreciate the support of the Alaska Department of Transportation and Public Facilities (ADOT\&PF) for this study, specifically Leo Woster and Dave Bloom of the Northern Region ADOT\&PF and Jack Stevenson of the Cordova Maintenance Facility of ADOT\&PF. This study was funded under State of Alaska Project COPPER RIVER HWY MP 27-49 HYDROLOGY STUDY-AKSAS 61959. Phase I of this study was a short reconnaissance study from August to September 2004. During this period, three sets of discharge measurements were made at Bridges 331 , 1187, 332, 339, 340, and 342. These measurements indicated significant channel changes in the Copper River had taken place. Based on the results of the phase I study, a phase II technical proposal was prepared. Work elements were defined, completed, and summarized in this report.

\section{References Cited}

Brabets, T.P., 1997, Geomorphology of the Lower Copper River, Alaska: U.S. Geological Survey Professional Paper 1581, 89 p.

Julien, P.Y., 1998, Erosion and sedimentation: Cambridge University Press, 280 p.

Kachadoorian, Reuben, 1968, Effects of the earthquake of March 27, 1964, on the Alaska highway system: U.S. Geological Survey Professional Paper 545-C, 66 p.

Maddock, Thomas, Jr., 1969, The behavior of straight open channels with movable beds: U.S. Geological Survey Professional Paper 622-A, 70 p.

McDonald, R.R., Bennett, J.P., and Nelson, J.M., 2001, The USGS multi-dimensional surface water modeling system, in Proceedings, $7^{\text {th }}$ U.S. Interagency Sedimentation Conference: Reno, Nevada, p. I-161-I-167.

McDonald, R.R., Bennett, J.P., and Nelson, J.M., 2005, Multidimensional surface water modeling system user's guide: U.S. Geological Survey Techniques and Methods Report, book 6, section B, chap. 6, 156 p., accessed at http:// wwwbrr.cr.usgs.gov/gstl/WebHelp Pro/MD SWMS.htm

Nelson, J.M., Bennett, J.P., and Wiele, S.M., 2003, Flow and sediment-transport modeling, in Kondolf, G.M., and Piegay, H., eds., Tools in fluvial geomorphology: England, Wiley, p. 539-576.

Nelson, J.M., and McDonald, R.R., 1997, Mechanics and modeling of flow and bed evolution in lateral separation eddies: Bureau of Reclamation, Glen Canyon Environmental Studies Report, 69 p.

Plafker, George, 1969, Tectonics of the March 27, 1964, Alaska earthquake: U.S. Geological Survey Professional Paper 543-I, 74 p.

Quinn, A.O., 1995, Iron rails to Alaskan copper-The epic triumph of Erastus Corning Hawkins: Bend, Oregon, Maverick Publications Inc., 195 p.

Schumm, S.A., and Winkley, B.R., 1994, The character of large alluvial rivers, in Schumm, S.A., and Winkley, B.R., eds., The variability of large alluvial rivers: New York, American Society of Civil Engineers, p. 1-9.

Wahrhaftig, Clyde, 1965, Physiographic divisions of Alaska: U.S. Geological Survey Professional Paper 482, 51 p., 6 pls. 
This page intentionally left blank. 
Publishing support provided by the U.S. Geological Survey Publishing Network, Tacoma Publishing Service Center

For more information concerning the research in this report, contact the Director, Alaska Science Center

U.S. Geological Survey

4210 University Drive

Anchorage, Alaska 99508

http://alaska.usgs.gov 
